\title{
Mineral resources and prospectivity of non-ultramafic rocks of New Caledonia
}

\author{
Maurizot P. ${ }^{1,}{ }^{*}$, Sevin B. ${ }^{1}$, Lesimple S. ${ }^{1}$, Collot Julien ${ }^{1}$, Jeanpert J. ${ }^{1}$, Bailly L. ${ }^{2}$, Robineau B. ${ }^{1}$, \\ Patriat Martin ${ }^{3}$, Etienne S. ${ }^{1}$, Monnin C. ${ }^{4}$
}

${ }^{1}$ Service Géologique de Nouvelle-Calédonie (New Caledonia Geological Survey), BP M2, 98 849, Nouméa, New Caledonia

${ }^{2}$ Bureau de Recherches Géologiques et Minières (French Geological Survey), 3 Avenue Claude

Guillemin, BP 36 009, 45 060, Orléans, France

3 Ifremer, UR Géosciences Marines, 29280 Plouzané, France

${ }^{4}$ Centre National de la Recherche Scientifique - Institut de Recherche pour le Développement, Géoscience Environement Toulouse, Observatoire Midi-Pyrénées, Université de Toulouse, 14 Avenue Edouard Belin, 31400 Toulouse, France

* Corresponding author : P. Maurizot, email address : pierre.maurizot@gouv.nc

\begin{abstract}
:
The mineral resources of the non-ultramafic rocks of New Caledonia and its Exclusive Economic Zone can be classified according to their host rocks. The metallic mineral resources are essentially associated with volcanic and magmatic activity. Non-economic volcanogenic massive sulfide deposits with $\mathrm{Cu}$ and $\mathrm{Au}$ are located in the Late Carboniferous Koh Ophiolite and in the Late Cretaceous Poya Terrane. Base metals, $\mathrm{Au}$ and $\mathrm{Ag}$ of the sedimentary-exhalative type are present in the metamorphic Diahot-Panié Metamorphic Complex, associated with syn-rift volcanism. An Au-Sb metallogenic province is associated with the post-obduction Late Oligocene granitoids and co-genetic hydrothermal silica-carbonate (listwanite) zones in the Peridotite Nappe; Au is disseminated in the granites and Sb occurs as lodes in the silica-carbonate. Among the non-metallic mineral resources, barite, gypsum, magnesite, phosphate, clays, dimension stones, limestone for use as cement and as a neutralizer, and aggregates are all present. Gemstones such as jade and chrysoprase are only used locally. Late Cretaceous coal, which was briefly exploited in the past, is now considered to be a source rock for an offshore potential oil and gas system. Petroleum prospectivity is currently focused on the Fairway Basin. Several low-enthalpy thermo-mineral springs with a weak geothermal energy potential are known on Grande Terre.
\end{abstract}




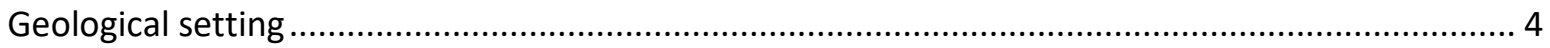

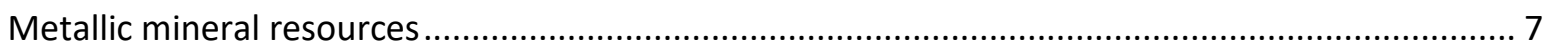

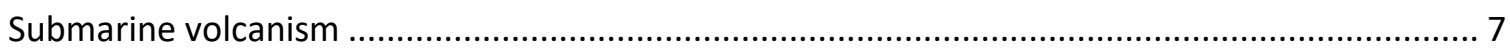

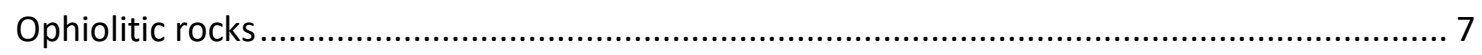

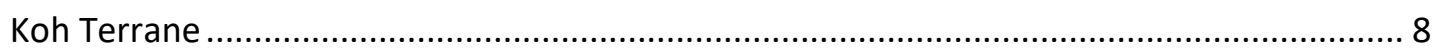

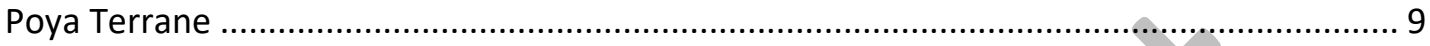

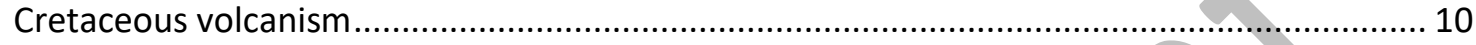

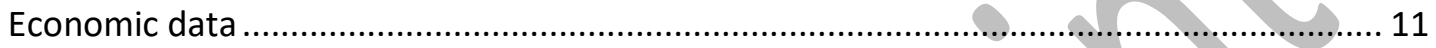

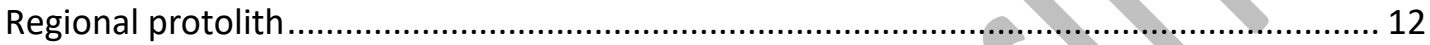

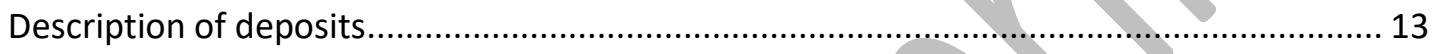

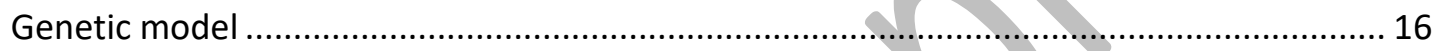

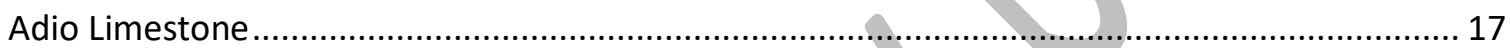

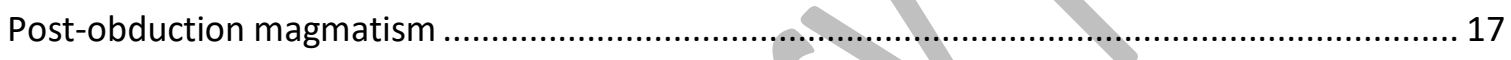

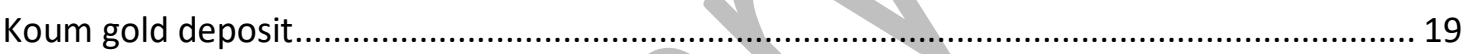

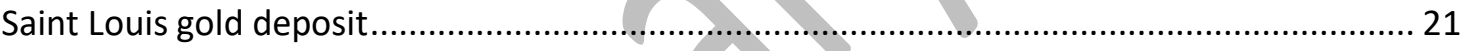

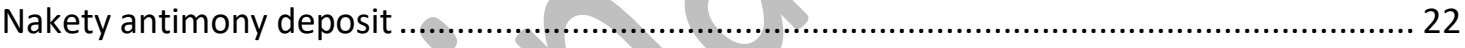

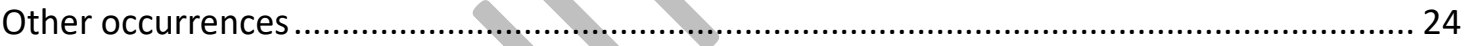

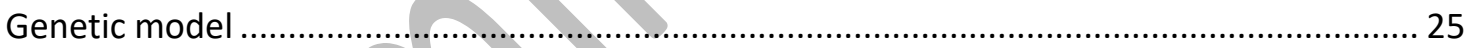

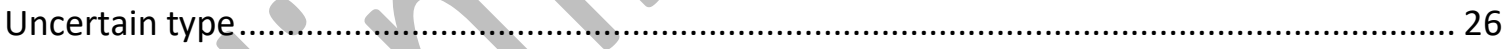

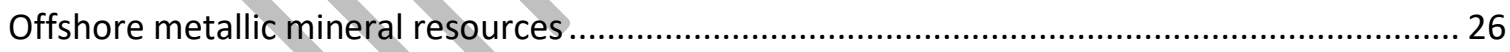

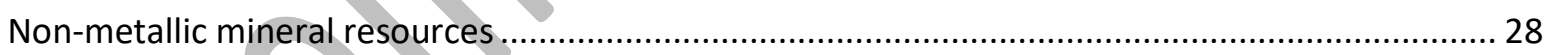

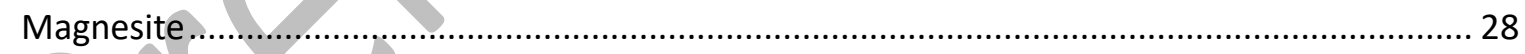

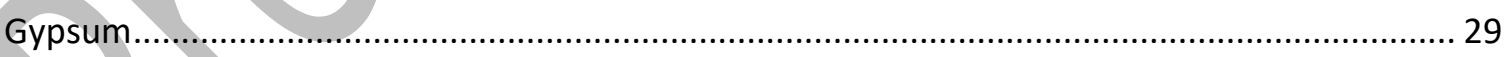

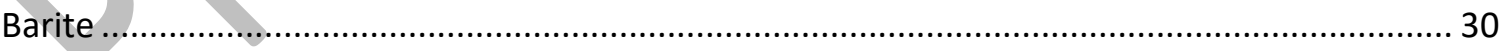

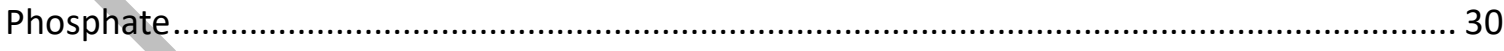

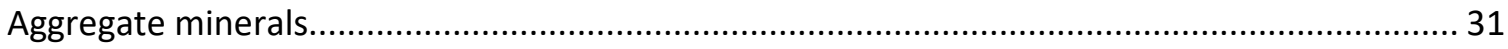

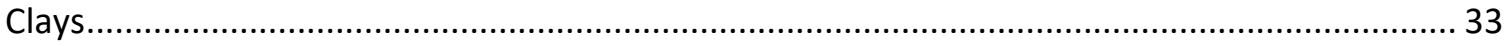

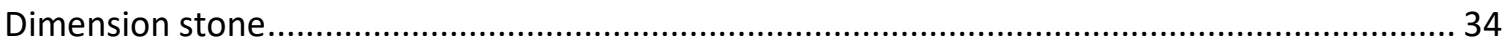

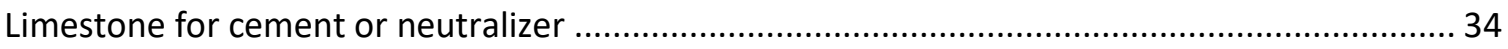

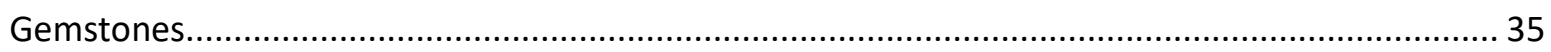

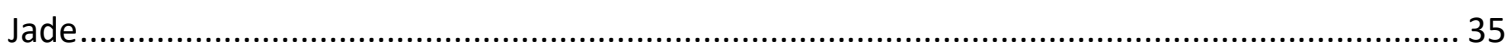

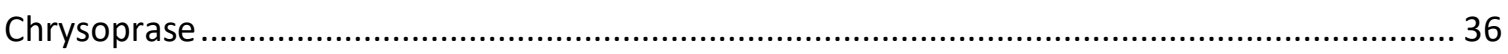




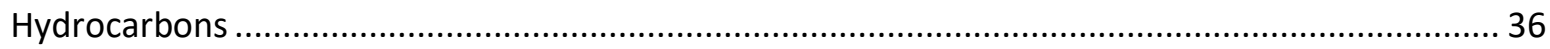

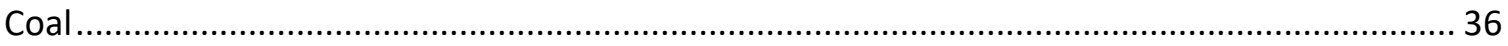

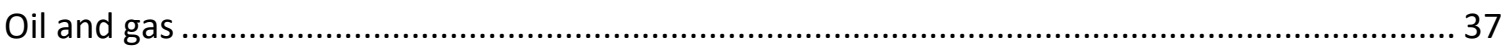

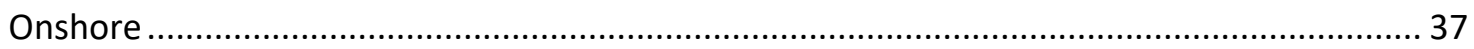

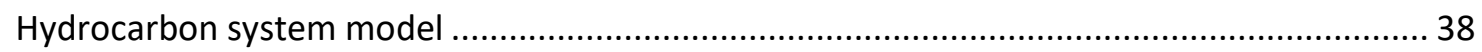

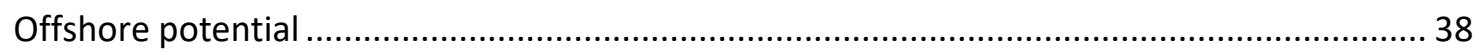

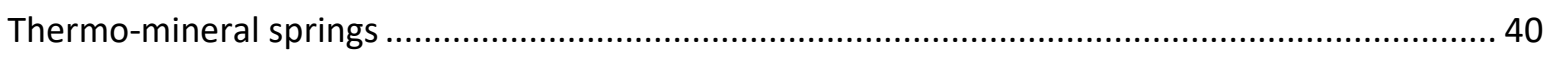

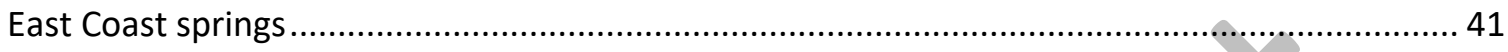

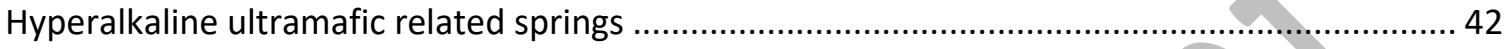

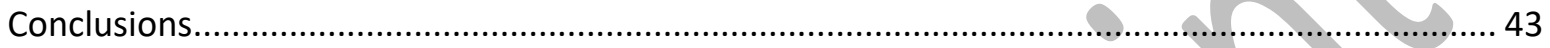

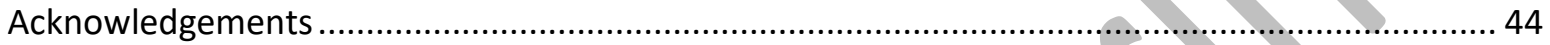

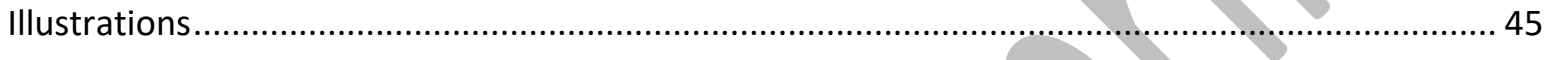

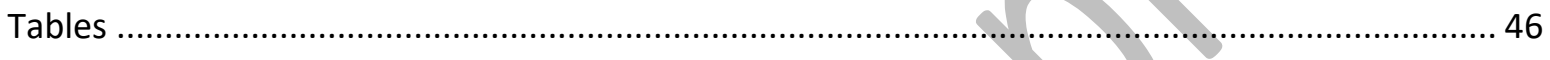

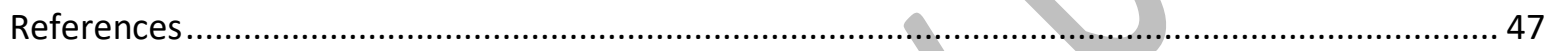


The mineral resources of New Caledonia are strongly controlled by its specific geology, which is dominated by mafic-ultramafic ophiolitic and arc-related lithologies. This chapter is devoted to the mineral resources, metallic or not, unrelated to ultramafic terrane. Mineral resources hosted by the Peridotite Nappe are the object of chapter 10, this memoir. Those resources which are present in both ultramafic and non-ultralafic terranes (e.g. thermo-mineral springs or gemstones) are grouped for convenience in this chapter. The metallic resources unrelated to ultramafic terrane are essentially associated with volcanic and magmatic activity.

New Caledonia's mineral resources have been estimated repeatedly during its history, at the initiative of government authorities. The first assessment of the natural resources of the country was conducted soon after colonization (Garnier 1867a, b, c) and led rapidly to the discovery of nickel. In the early 1980s, due to the drop in nickel price, the French Government launched a systematic mineral exploration programme aiming at diversification of the mining industry. This "Mineral Resources Survey" programme was conducted by the French Bureau de Recherches Géologiques et Minières (BRGM) between 1980 and 1990. It comprised greenfield surveys (stream sediments and alluvial concentrates) and brownfield exploration (soil geochemistry, geophysics, drillings), and involved all metals except nickel. It led to the development of a few prospects, especially gold, which were subsequently held by junior companies. Although this programme ultimately did not lead to the discovery of new economic-size deposits, it resulted in acquisition of priceless knowledge and scientific advances.

In the 1990s the ZoNéCo programme (Zone Economique de Nouvelle-Calédonie), was launched to explore the Economic Exclusive Zone (EEZ) of New Caledonia in order to assess its offshore resources (Ducrocq et al. 2012; Grandperrin et al. 1997). Part of this programme, still active in 2016, is specifically devoted to hydrocarbon potential linked to thick sedimentary piles, deposited on shore and offshore.

In this paper, the terminology, such as reserve and resource, is used in compliance with recommendations and guidelines of instances such as the Committee for Mineral Reserves International Reporting Standards (CRIRSCO). A mineral occurrence is of geological interest but not necessarily of economic interest. A prospect is a mineral deposit on which some preliminary prospection or mining works have been done. A mineral deposit is a generic term applying to a concentration of material, economic or not. A mineral resource is a concentration of material economically and technically feasible or not. A mineral reserve is the economically mineable part of the mineral resource.

Information on many of these resources (e.g. coal, base metal, chromium, gold, gypsum, etc.) is only documented in unpublished reports in the French language, most of them available in the archive of the New Caledonia government administration in charge of mines: Direction de l'Industrie, des Mines et de l'Energie de Nouvelle-Calédonie (DIMENC). Irrespective of abundance or importance, all known mineral occurrences, prospects and deposits are presented in this memoir at their current state of knowledge and unpublished references are cited for the sake of completeness.

\section{Geological setting}

The mineral resources addressed in this chapter, are presented by genetic type rather than by chronological order. For easier reading, the main outlines of the geology of the archipelago are presented first (Fig. 1), with emphasis on those units having mineral resources or potential. 
The geological evolution of Grande Terre, the main island of New Caledonia, may be divided into four phases (Cluzel et al. 2012).

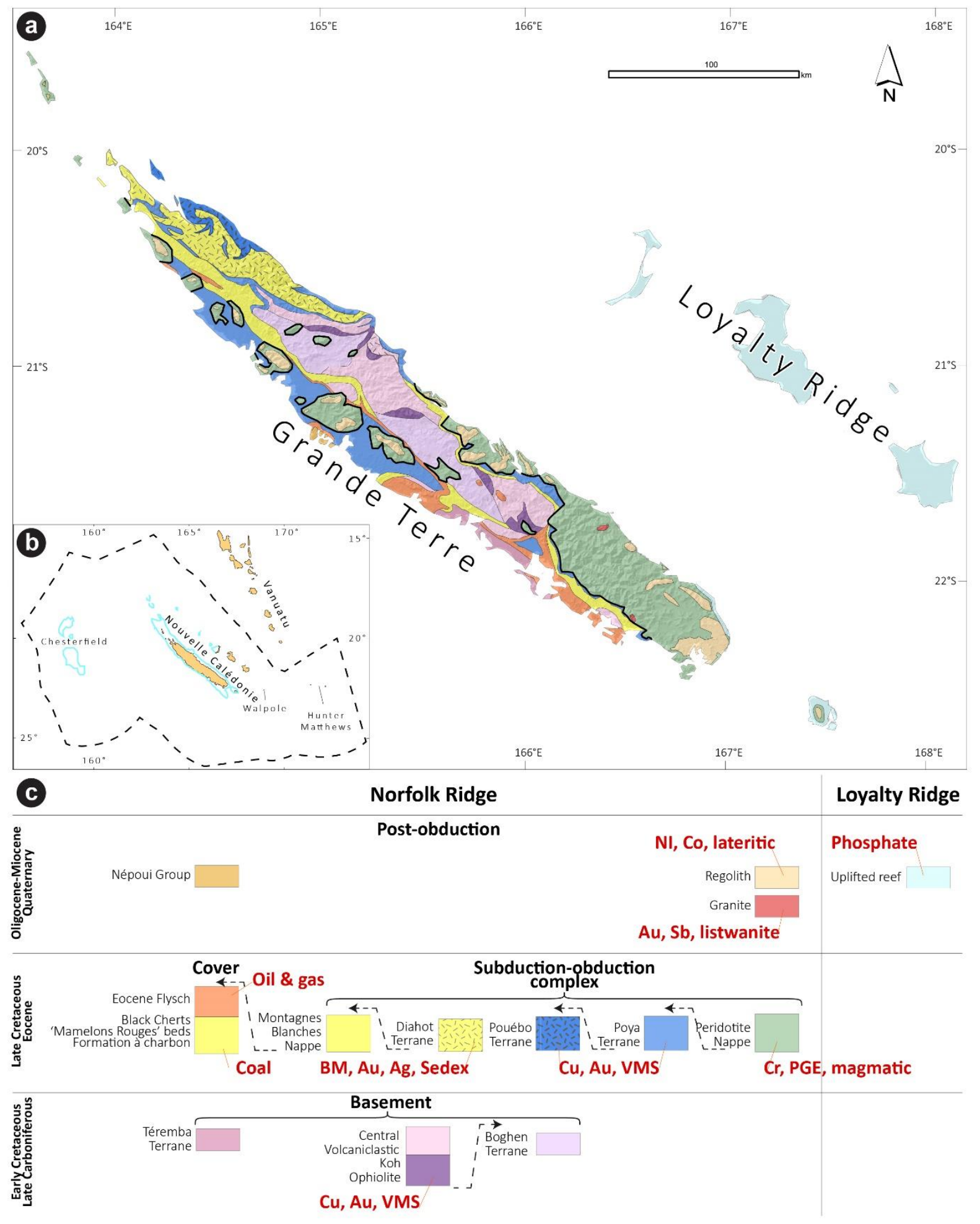

Fig. 1 a) Geological map of New Caledonia. b) EEZ of New Caledonia and position of some remote islands. c) Legend showing (in red) main metallic mineral resources (including ultramafic related, cf. chapter 10, this memoir), hydrocarbons, phosphate, and their associated terrane. VMS: Volcanogenic Massive Sulphide; Sedex: Sedimentary Exhalative; BM: Base Metals. 
The Late Carboniferous to Early Cretaceous period, is marked by west-dipping subduction along the eastern Gondwanaland margin. At that time, proto-New Caledonia was located in a fore-arc region in which volcanic-arc detritus accumulated whilst oceanic and terrigenous material accreted from the east. The amalgamation of the three resulting terranes constitute the 'basement' of New Caledonia (cf. chapter 3, this memoir, and Maurizot et al. in press). Téremba Terrane is composed of deep-sea Permian to Mesozoic arc-derived volcanic rocks and greywackes. The Koh-Central Terrane includes at its base an ophiolite (Koh Ophiolite) of Late Carboniferous to Early Permian (Aitchison et al. 1995a; Meffre et al. 1996) age overlain by a thick sequence of greywacke (Central Range volcaniclastic rocks) of Permian to Late Jurassic age. The Boghen Terrane is a High Pressure - Low Temperature (HP-LT) metamorphic subduction complex composed of schists, broken formations, and mafic/ultramafic mélange, derived from mixed terrigenous and volcanic sources, Early Jurassic to Early Cretaceous in age.

After this prolonged period of convergence, the eastern Gondwana margin underwent a rapid change to extensional tectonics, evidenced by a major angular unconformity between the older 'basement' rocks and the younger sedimentary 'cover' (cf. chapter 4, this memoir). During this Late CretaceousPalaeocene period, continental break up, and marginal rifting isolated New Caledonia in an intraoceanic setting. After a Late Cretaceous period of shallow water terrigenous sedimentation, including coal deposits ('Formation à charbon') associated with volcanic activity, pelagic sediments ('Mamelons Rouges' beds then Black Cherts) accumulated during post-rift thermal subsidence (Aitchison et al. 1995b).

At the Paleocene-Eocene boundary, a new NE-dipping subduction appeared to the east of New Caledonia (Cluzel et al. 2001) that led to the formation of the 'subduction-obduction complex' (cf. chapter 5, this memoir). In this new convergence zone, the northern tip of the Norfolk Ridge is gradually subducted during the Eocene, and metamorphosed to HP-LT schists and gneisses. The exhumed parts of this subduction complex form the Diahot and Pouébo terranes (Cluzel et al. 1994). At the front of the convergence zone, a typical thick turbidite succession, the Eocene Flysch, accumulated in a flexural foreland basin propagating from NE to SW (Maurizot 2014). The subduction blocked when the Norfolk Ridge entered the convergence zone at the end of Eocene. This collisional and obduction stage resulted in the SW-ward in-sequence stacking of allochthonous terranes over the Norfolk Ridge: successively the margin of the Norfolk Ridge (Montagnes Blanches Nappe, Maurizot 2011), the oceanic crust of the South Loyalty Basin (SLB, Poya Terrane), and finally the Peridotite Nappe, deep mantle sequence of the Loyalty Basin (Cluzel et al. 2001).

The 'post-obduction formations' (cf. chapter 7, this memoir) are represented by a variety of geological units. Two calc-alkaline granites (Saint Louis and Koum) of Late Oligocene age (Cluzel et al. 2005) are intruded both in the peridotite nappe and its substrate. They are associated with extensive hydrothermalised zones of silicification and carbonatisation in the peridotite. Finally, during Neogene, New Caledonia definitively emerged; In the terrestrial domain, this period mainly corresponds to prominent regolith development under tropical climate, and intramontane deposits, the FluvioLacustrine Formation, (Folcher et al. 2015) on the Peridotite Nappe. It lead to the development of supergene nickel ores as well (cf. chapter 10, this memoir). In the marine domain, mixed carbonate and siliciclastic platform deposits (Maurizot et al. 2016) lead offshore to deep basinal deposits. 
The geology of the Loyalty Ridge is poorly known (cf. chapter 6, this memoir). The ridge is formed by seamounts of volcanic origin, covered by thick Miocene to Recent carbonate platform.

Mathew and Hunter Islands (cf. chapter 2, this memoir), the easternmost islands of the New Caledonian archipelago, are isolated volcanoes located on the southern tip of the Vanuatu island arc, marking one of the active convergent boundaries between the Pacific and Australian plates.

The Chestefield Islands (cf. chapter 2, this memoir), the westernmost islands of New Caledonia, are atolls built on intra-oceanic volcanoes that belong to the NS Lord Howe hotspot trail, roughly parallel to the eastern coast of Australia.

\section{Metallic mineral resources}

\section{Submarine volcanism}

A number of base metal, gold, and silver of the generic volcanogenic massive sulphide (VMS) type (Large 1992), together with some manganese occurrences, are known in various volcano-sedimentary terranes of the basement, cover, and ophiolitic allochthons. The deposits typically result from leaching by volcanic-related hydrothermal convective circulation of seawater-derived fluids in the country rocks, then precipitation, at or immediately below the seafloor by venting of hot metal-bearing solutions. These deposits typically combines a lower root where fluids are entrapped in a stockwork of veinlets crosscuting the host rock (stringer zone), and an upper, more or less stratiform body where fluids are deposited in the open sea, and are interfingered with the surrounding sediments, if present.

\section{Ophiolitic rocks}

Subordinate exhalative hydrothermal deposits with copper, gold, of modest sizes are hosted by both the sedimentary rocks and the mafic volcanic rocks of the two main ophiolitic crustal terranes of New Caledonia i.e. the Paleozoic Koh Ophiolite and Mesozoic Poya terranes (Fig. 2). 


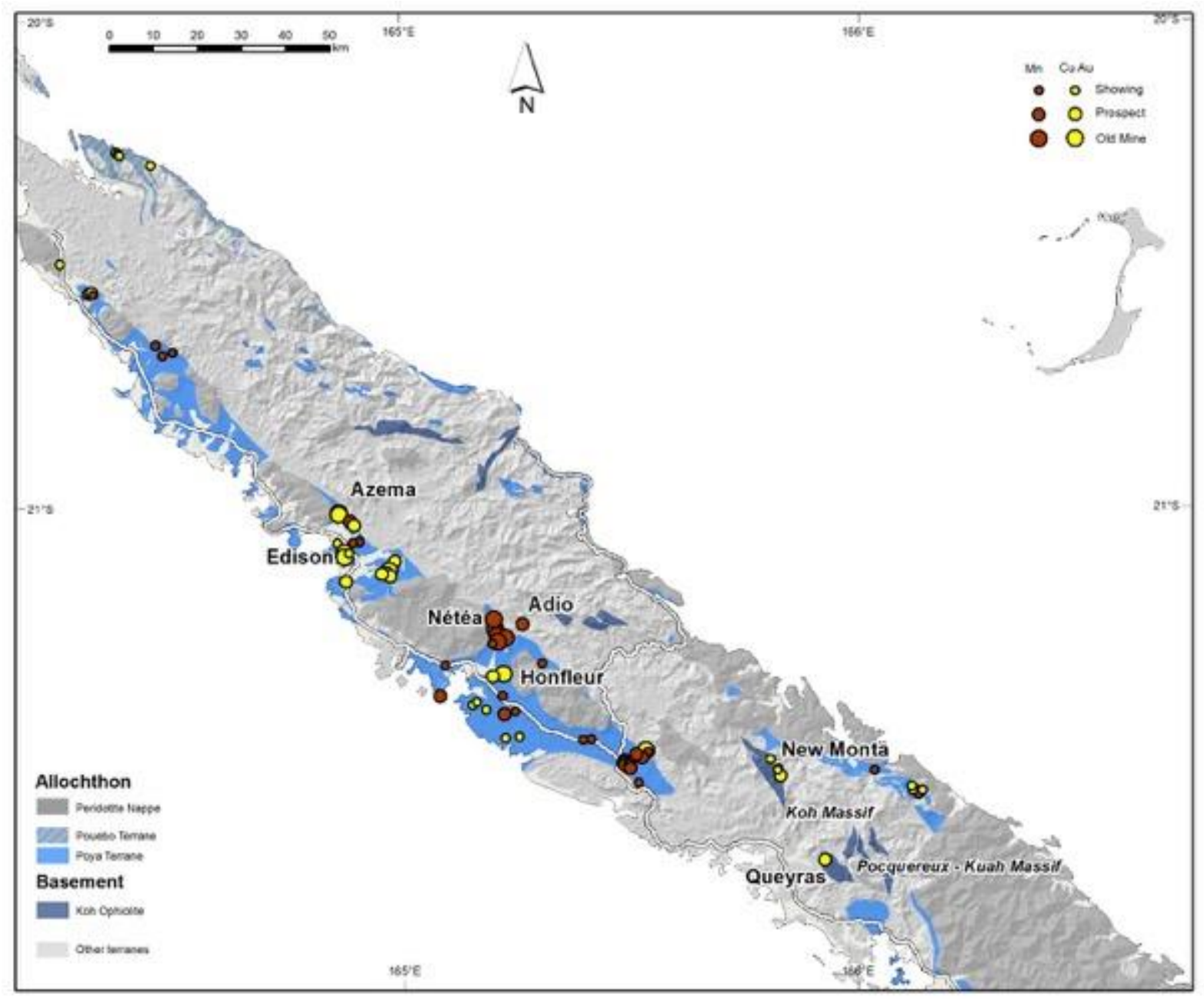

Fig. 2 Locations of the main VMS and manganese deposits in the Koh Ophiolite and Poya Terrane.

\section{Koh Terrane}

The Koh-Central Terrane (Meffre 1995) includes the Late Carboniferous to Early Permian Koh Ophiolite (Aitchison et al. 1998), and its Central Range volcaniclastic sedimentary cover (Aitchison et al. 1995). The Koh ophiolite is composed of dismembered fragments of oceanic crust comprising gabbro cumulate, dolerite, dyke complex, pillow basalt, breccias, flows, pyroclastic deposits, and radiolarian chert. Boninite are known In the Koh massif (Cameron 1989; Meffre 1995; Meffre et al. 1996).

In the Koh massif, the New Monta prospect consists of several occurrences of copper and gold, extending discontinuously over $2 \mathrm{~km}$ along strike. Disused workings, as old as 1875 , consist of several trenches, addits and pits of c. $10 \mathrm{~m}$ in size. More recently, a Mineral Resources Survey programme (BRGM 1987a, BRGM 1981) consisted of a stream sediment survey, soil and rock geochemistry, geophysics, drillings, and detailed geological mapping. Sulphides at New Monta occur as small quartz veins, silicified brecciated zones, or disseminated crystals in boninites, tholeiites, pelagic cherts and tuffs of the top of the Koh Ophiolite. No mineralization is reported from the underlying layered gabbros. The Cu content is generally below $1 \%$, although it may reach $6 \%$ very locally, in local gossan. The average Au content is below $1 \mathrm{ppm}$ in fresh rock but may occasionally reach 5 to $35 \mathrm{ppm}$ in gossan. $\mathrm{Ag}$ is also present in oxidised zones with a grade of 1 to $2 \mathrm{ppm}$. Sulphides comprise chalcopyrite with minute inclusions of palladium telluride, galena, and electrum, pyrite (commonly nickeliferous), and 
pyrrhotite. Sulphides are associated with oxydes, as chromite, chromium-spinel, ilmenite, and rutile (BRGM 1981). The presence of $\mathrm{Ni}, \mathrm{Cr}$ and $\mathrm{Pd}$ in the mineralization is consistent with boninite host rock (cf. chapter 3, this memoir).

The Queyras prospect (BRGM 1982) was discovered in 1896 in the Pocquereux - Kuah ophiolitic massif. A few pits, adits, and a quarry were excavated in fractured basalt overlain by gossan extending over a maximum of $100 \mathrm{~m}$. Sulphides appear in a stockwork of quartz veins and in basalts heavily altered to chlorite and epidote. The paragenesis is made up of pyrite and magnetite with inclusions of chalcopyrite, pyrrhotite, galena, and pearceite ( $\mathrm{Ag}, \mathrm{Cu}$, As sulphide) derived from hydrothermal deposits of low to medium temperature. Grades in the gossan are as high as 70 ppm Au and 20 ppm Ag. A few tons of ore were extracted and exported.

Both the New Monta and Queyras deposits have been formed in an oceanic seafloor setting. They are dominantly vein deposits corresponding to hydrothermal pipe and stockwork zone in basalts, and subordinately hosted in exhalative sedimentary rocks.

\section{Poya Terrane}

The Poya Terrane (Aitchison et al. 1995b; Cluzel et al. 1995b; Cluzel et al. 2001) corresponds to a pile of stacked, scraped-off slices of oceanic crust, overthrust onto the New Caledonia autochthonous basement (Norfolk Ridge) below the Peridotite Nappe. Its age is Late Cretaceous (Campanian) to Paleocene. This crustal ophiolitic unit is composed of pillow lava basalts, dolerites, fine grained gabbros, and subordinate sediment intercalations. It is devoid of any mantle or cumulate sequences. E-MORB tholeiites are preponderant over IAT, BABB and depleted N-MORB tholeiites. Minor, variously colored, sedimentary intercalations are red, green, white or black ferro-manganiferous jaspers, radiolarian cherts, and argillites which represent thin draping of abyssal sediments deposited over the oceanic floor.

The basaltic protolith is often cross cut by hydrothermal veins whose proportion may sometimes be higher than the host rock. Such host rocks are uniformly and pervasively affected by a hydrothermal sub-seafloor low grade metamorphism related to hot rock and sea water interaction. The whole is severely disrupted and cross cut by numerous shear planes and tension gashes. Interbedded sedimentary inliers are generally fault-bounded and dip steeply (Cluzel et al. 2001).

Poya Terrane VMS deposits are linked to sedimentary inliers and are copper and gold dominant (Bache 1981; Bache \& Wilhelm 1980; BRGM 1980). No stringer zone with quartz-sulphide veins has been identified so far, owing to the bad quality of outcrops, severe tectonic disruption, and small size of the deposits. Barite together with silica as quartz-chalcedony is a gangue mineral in several deposits. The size of the deposits are modest; c. 10 to $50 \mathrm{~m}$ long, highly contorted, folded and faulted, with an average thickness of c. $1 \mathrm{~m}$, exceptionally and locally $10 \mathrm{~m}$ (Honfleur mine). Deposits were all primarily identified by their gossan in which Au content was commonly enriched to over $100 \mathrm{ppm}$, and exceptionally 1000 ppm. In the non-oxidized zone, Cu content is c. 5-15\%, Au 1-10 ppm and Ag 0-50 ppm. Sulphides are chalcopyrite and pyrite (euhedral or collomorphic) with common spheroidal or framboidal textures. Electrum and native gold grains (up to $200 \mu \mathrm{m}$ in Edison mine) are frequent. Accessory minerals are sphalerite, galena, tetrahedrite, and $\mathrm{Ni}$ bearing species like gersdorffite and melonite (a nickel telluride, Bache 1981). 
In the Azema deposit, clusters of unjointed worm tubes made up of pyrite with an annealed structure in the quartz-barite gangue of the massive sulphide ore have been reported (Oudin et al. 1985), 1 to 2 $\mathrm{mm}$ in length and $300 \mu \mathrm{m}$ in diameter, representing the remains of a former seafloor hydrothermal vent with its associated living community.

The Pouébo Terrane is a metamorphic high pressure - low temperature metamorphosed equivalent of the Poya Terrane, underplated at depth c. $70 \mathrm{~km}$, with which it shares both geochemical composition (Cluzel et al. 2001) and age of formation (Spandler et al. 2004a; Spandler et al. 2004b; Spandler et al. 2005). It corresponds to a chaotic mixture of boulders within a metasedimentary or serpentinite matrix (Maurizot et al. 1989) metamorphosed to eclogite facies then retrograded through blueschist to greenschist facies. Several small occurrences of $\mathrm{Cu}$ and $\mathrm{Au}$ sulphide deposits in this unit are metamorphosed equivalent of the Poya Terrane VMS deposits.

VMS deposits of the Poya and Pouébo Terrane are of the Cyprus type (Constantinou 1980), deposited in oceanic seafloor settings, far from any clastic source. Individual extracted tonnages are of the order of a few hundred tons, to be compared to the $1.6 \mathrm{Mt}$ average tonnages of the Cyprus type (Mosier et al. 2009).

Small manganese deposits in the Poya Terrane have been sporadically quarried from 1918 to 1922 then from 1949 to 1953 (Arnould 1954, 1956). The overall extracted tonnage is $61000 \mathrm{t}$ for this two periods with a Mn content of c. $50 \%$ and 10 to $20 \%$ Si. Deposits are clearly associated with abyssal sedimentary intercalations of argillite and chert, and display the same structural complexity. The ore is mainly composed of braunite also with psilomelane and pyrolusite. Barite is an accompanying mineral (Arnould 1954). Individual lenses are c. 10 to $100 \mathrm{~m}$ in length and c. 1 to $10 \mathrm{~m}$ in width, for a maximum tonnage of $10000 \mathrm{t}$. These volcanogenic sedimentary deposits have no clear spatial relations with the $\mathrm{Cu}$-Au bearing VMS.

In some places (e.g. Nétéa) primary manganese deposits are enriched and concentrated in weathering profiles, as Mn-rich red clays including residual boulders of $\mathrm{Mn}$ bearing cherts.

\section{Cretaceous volcanism}

Base metal and gold deposits of the Diahot Basin, in the north of New Caledonia (Fig. 3), were discovered early after the colonization, in the 1870s, soon after the Australian (1850s) and New Zealand (1860s) gold rushes. Despite their modest size, they led to several waves of interest, speculation, hope, and disappointment. The Fern Hill gold deposit was the first one to be discovered and, because of this, gold was the first metal to be extracted in New Caledonia, before nickel (Black 2004). Other deposits of base metals were discovered and exploited subsequently. Mining works progressively declined until 1895, and by the eve of WWI, most operations had ceased. All following attempts to revive the mining, throughout the 20th century, even with modern exploration tools and appropriate metallogenic models, were unsuccessful. The last reassessment of the Diahot Basin metallogenic potential was made in the 1980 s by the Mineral Resource Survey French governmental programme, operated by the BRGM (Aye 1982; Bache 1981; BRGM 1981, 1986c, 1987a; Maurizot 1981). Following this programme, several promoted targets were taken by junior companies but no economic target arose. The geological context and the metallogeny of the deposits were at least scientifically studied. 
Base metal and gold deposits of the Diahot Basin are located in the HP-LT metamorphic complex of the north of the island which comprises the Diahot and Pouebo terranes (Clarke et al. 1997; Cluzel et al. 1995a; Cluzel et al. 1995c), subducted during Late Eocene. The deposits are stratiform, hosted in sedimentary rocks and related to the volcanic activity and rocks of the Late Cretaceous Diahot Terrane (Cluzel et al. 2012; Maurizot et al. 1989). The metamorphic grade is blueschist (lawsonite glaucophane blueschists) on the true left bank (SW) of the Diahot River and eclogite (omphacite garnet) on the true right bank (NE). Interestingly, the same Late Cretaceous cover in the Noumea area, with a very similar lithology (Noesmoen 1970), but a slight different geochemistry and unmetamorphosed (Black 1995; Nicholson et al. 2011), is sterile in term of metal deposits.

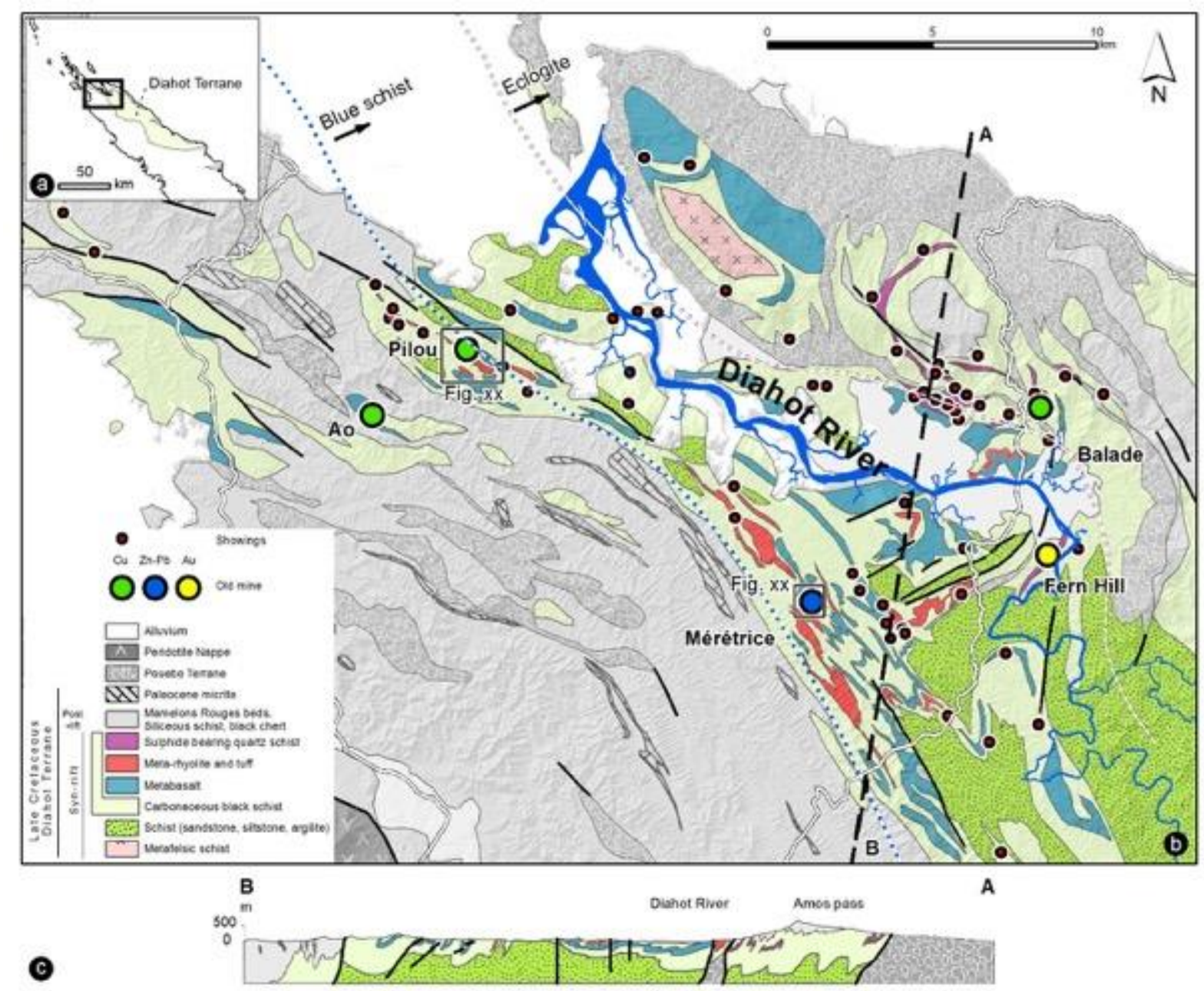

Fig. 3 Diahot Basin geological map and mineral deposits: a) Extent of the Late Cretaceous Diahot Terrane. b) Geological map. c) Cross section.

\section{Economic data}

A total of sixty prospects have been identified and explored in the Diahot Basin, but only five deposits, with significant size and tonnage, were mined (Table 1).

\begin{tabular}{|c|c|c|c|c|c|c|}
\hline Name & Element & Minerals & Production & Reserve & Activity & Grade \\
\hline
\end{tabular}




\begin{tabular}{|c|c|c|c|c|c|c|}
\hline Pilou & $\mathrm{Cu},(\mathrm{Pb}, \mathrm{Zn})$ & $\begin{array}{l}\text { Chalcopyrite, } \\
\text { sphalerite, } \\
\text { galena }\end{array}$ & $70000 t$ & $90000 t$ & $1884-1910$ & $\begin{array}{c}\text { Cu } 10 \% \\
\text { Zn Pb } 5 \%\end{array}$ \\
\hline Ao & $\mathrm{Cu},(\mathrm{Pb}, \mathrm{Zn})$ & $\begin{array}{l}\text { Chalcopyrite, } \\
\text { sphalerite, } \\
\text { galena }\end{array}$ & 0 & $30000 t$ & $1887-1900$ & $\begin{array}{c}\text { Cu } 15 \% \\
\text { Pb } 1 \% \\
\text { Ag } 100 \mathrm{~g} / \mathrm{t}\end{array}$ \\
\hline Mérétrice & $\mathrm{Zn}, \mathrm{Pb},(\mathrm{Ag})$ & $\begin{array}{l}\text { Sphalerite, } \\
\text { galena, } \\
\text { chalcopyrite }\end{array}$ & $15000 t$ & $35000 t$ & $1884-1930$ & $\begin{array}{c}\text { Zn } 30 \% \\
\text { Pb } 15 \% \\
\text { Cu } 5 \% \\
\text { Ag } 200 \mathrm{~g} / \mathrm{t}\end{array}$ \\
\hline Ballade & $\mathrm{Cu}$ & Chalcopyrite & $60000 t$ & $\begin{array}{c}100000 \mathrm{t} \\
5 \% \mathrm{Cu}\end{array}$ & $1872-1884$ & Cu $20 \%$ \\
\hline Fern Hill & $\mathrm{Au},(\mathrm{Zn}, \mathrm{Pb})$ & $\begin{array}{l}\text { Native gold, } \\
\text { (sphalerite, } \\
\text { galena) }\end{array}$ & $213 \mathrm{~kg}$ & $?$ & $1870-1$ & $\begin{array}{c}\text { Au } 1-100 \\
\mathrm{~g} / \mathrm{t}\end{array}$ \\
\hline
\end{tabular}

Table 1 Summary of metallogenic and economic data of the main mines of the Diahot Basin. Locations on Fig. 3. Mined tonnages or reserves do not exceed $100000 \mathrm{t}$.

\section{Regional protolith}

The Late Cretaceous sedimentary rocks of the Diahot Terrane correspond to a rifted margin megasequence, deposited on the northern thinned margin of the Norfolk Ridge, with syn-rift terrigeneous deposits towards the base and post-rift finer-grained deposits towards the top. A few fossil occurrences and lithological comparisons with unmetamorphosed areas to the south enable to reconstruct a general stratigraphic column, despite the complex and polyphased deformation and metamorphism (Maurizot et al. 1989).

To the SW of the Diahot River, the syn-rift terrigenous meta-sandstones, -siltstones, and -argillites, are well exposed although a basal conglomerate, if any, is not known. This unit extends toward the SE over considerable surfaces in the remote area, covered by tropical forest of the Mont Panié Massif (Fig. 3a). It grades upward into a series of very fine grained, organic-rich, carbonaceous black argillites, metamorphosed as black phyllitic schists. This black schists are interbedded with volcanic rocks of bimodal composition. Mafic lavas are dolerite or porphyric basalts of transitional tholeiite to alkaline affinities (Cluzel et al. 2011; Cluzel et al. 1995c; Picard 1995). An intrusive origin as sills has been proposed (Briggs 1977) because of the lack of co-eval mafic pyroclastic sediments and sharp contact with the enclosing schists, but is difficult to ascertain in such a metamorphic context. Acidic lavas are rhyolite and rhyodacites with phenocrysts of K-feldspars or plagioclase. Co-eval acidic tuff sequences, with volcanic quartz clasts, interbedded in the schists are common. Acidic lavas are commonly considerably altered with development of epigenetic quartz, phyllosilicates and oxidised sulphides. The rocks usually show strong iron staining and leaching. $\mathrm{Cu}$ and $\mathrm{Pb}$ content is frequently of the order of $100 \mathrm{ppm}$.

This unit passes transitionally upward to siliceous black schists, typical of the Mamelons Rouges beds (Tissot \& Noesmoen 1958), in which fossiliferous nodules yielded Late Cretaceous inoceramids in several localities. To the SW, in the unmetamorphosed area of Koumac, the Mamelons Rouges beds are assigned to the Coniacian-Early Campanian interval (Maurizot 2011). They grade upward into LateCampanian-Maastrichtian cherts, then to Paleocene micrite. 
The Late Cretaceous black schist and metachert sequences reflect a period of considerable reduction in terrigenous input and an anoxic bathyal environment, related to a post-rift thermal relaxation (Aitchison et al. 1995a).

\section{Description of deposits}

Deposits show a remarkable degree of bedding control from regional to macroscopic scales (Fig. 3 and fig. 4). Stratiform mineralisation likely took place during a short episode of the Late Cretaceous, in carbonaceous black argillites, and in association with volcanic activity. Sizes of orebodies are c. $100 \mathrm{x}$ $50 \mathrm{~m}$, for a maximum thickness of $1 \mathrm{~m}$. They are complexly folded. Massive layers of sulphides have a high grade in base metal, higher than $10 \%$. Exceptional grades of c. $35 \%$ are noteworthy at the $\mathrm{Pb}-\mathrm{Zn}$ deposit of Mérétrice.

Most of the deposits show varying degrees of compositional banding of sulphides and, in places, the sulphide ores show relict sedimentary textures (Briggs 1975, 1977; Briggs et al. 1978). In the Pb-Zn ores at Meretrice and Fern Hill the compositional layering consists of millimetric beds of galena, pyritechalcopyrite-rich layers, in a matrix of compact sphalerite. Small scale cross-bedding and slumping structures are visible in the layered ore. Pyrite framboids and atoll structures of sedimentary or diagenetic origin are also common. There are complex concentric structures with several envelopes of galena and pyrite in the ore at Meretrice. In Balade, Pilou, and Ao copper mines, the compositional layering in the compact massive chalcopyrite consists of millimetric to decimetric discontinuous trails of pyrite, sphalerite, and galena (BRGM 1987a).

Other lithologies are specifically associated with the deposits. Calc-silicate lenses and layers (Pilou, Mérétrice) are formed of massive heterogeneous breccias of quartz, calcite, and dolomite, with disseminated sulphides. Calcite is euhedral and seems to have crystallised directly in seawater before being cemented by quartz which fills voids. Quartz veins with euhedral ferrocarpholite are present in this facies which is frequently found in continuity either with rhyolite or with massive sulphide layers, e.g. at Pilou and Ao mines (Briggs 1978). Spotted black schists are also common. They show millimetre diameter, ellipsoid flattened porphyroblasts, with pressure shadows, filled with fibrous radiating aggregates of quartz, sericite, pyrophyllite, carpholite or chlorite. Fe-Mg-carpholite in the blue schist zone is replaced by a Fe-chloritoid in the higher grade eclogite zone, e.g. in the Ballade mine (Black et al. 1993).

Layers (after bedding) of sericite, chlorite, talc, or any combination of these phases, centimetre to decimetre in thickness, are also common in the vicinity of the deposits. Iron rich quartz chlorite-schists at Fern Hill and Ballade comprise hectometre to kilometre along-strike bodies hosting disseminated sulphide mineralization. All these lithologies are considered to result from sedimentation of hydrothermal exhalations, either proximal (calc-silicate) or distal (schists) from vents (Aye 1982). 


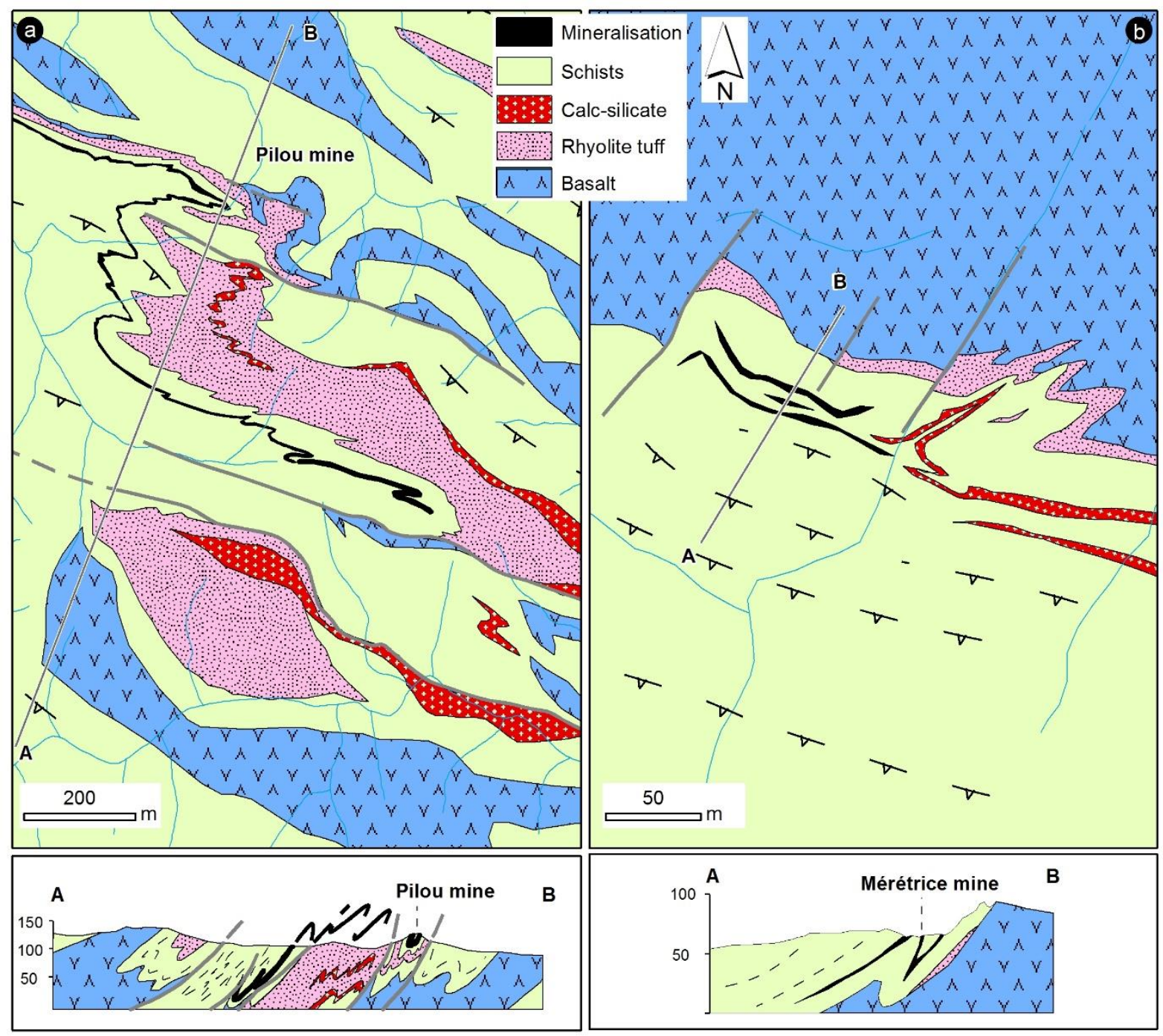

Fig. 4 Geological maps and cross sections of a) Pilou mine; b) Mérétrice mine.

In the Fern Hill gold mine, two types of mineralization occur. Type 1 corresponds to disseminated pyrite, arsenopyrite and other base metal sulphides in quartz schist or quartz-chlorite schist with barite, and discrete lenses of meta-acidic tuffs. Native gold is present as infra-millimetric grains in the pyritic ore. The "discovery trench" was opened on the oxidized part of this primary type deposit where contents from 100 to $1000 \mathrm{~g} / \mathrm{t}$ Au were reported. Type 2 corresponds to a massive rich layered $\mathrm{Zn}-\mathrm{Pb}$ ore (similar to the one at Mérétrice) with sphalerite and galena. This part of the orebody was reached later by deep underground works and subsequent drilling, and does not outcrop. Gold content of 380 $\mathrm{g} / \mathrm{t}$ corresponding to millimetric native gold particles in this ore were reported. A low base metal and gold background with localized high grade gold concentrations seems to be the rule. So far, controlling factors of the erratic gold contents are not known.

At Balade, there are so far no recognized acidic volcanic rocks associated with the ore. Sulphide lenses are intercalated in iron and disseminated sulphide-rich quartz-chlorite-schists that form a distinctive weathered rusty horizon, approximately $80 \mathrm{~m}$ thick, which extends over $2 \mathrm{~km}$ along strike. In this layer, massive chalcopyrite ore forms localized lenses. 
Even though there is a dominant metal in each deposit, each of them contains an amount, even if minor, of the $\mathrm{Cu}, \mathrm{Pb}, \mathrm{Zn}, \mathrm{Au}$, and $\mathrm{Ag}$. The $\mathrm{Cu}$ Ballade ore contains minor amount of gold (1 ppm in the gossan and 0.5 ppm in sulphide) and locally up to $200 \mathrm{ppm}$ Ag. Part of the Fern Hill Au deposit is rich in $\mathrm{Pb}-\mathrm{Zn}$. The $\mathrm{Pb}-\mathrm{Zn}-\mathrm{Ag}$ Mérétrice deposit contains minor amount of $\mathrm{Cu}$ and $\mathrm{Au}$ (1 ppm in the gossan). Because of this elemental consistency the deposits of the Diahot Basin can be considered as a single metallogenetic province (BRGM 1987a).

All the deposits are characteristically pyritic. $\mathrm{Cu}$ is the most abundant element, mainly as chalcopyrite, followed by $\mathrm{Zn}$ and $\mathrm{Pb}$ in sphalerite-galena layered ore. Sphalerite is the most abundant phase of the $\mathrm{Pb}-\mathrm{Zn}$ deposits, and contains inclusion of cassiterite. Au is in native form and is most significant at Fern Hill. Much less significant are Ag, As, Sb, Sn, Mo, Bi. Ag occurs in argentiferous galena at Meretrice. Arsenic is locally abundant, occurring in arsenopyrite and tetrahedrite. Laminae, rich in arsenopyrite and tetrahedrite occur at Meretrice where an almost monomineralic tetrahedrite layer is reported (Briggs 1977). Sb and As are in minerals from the tennantite-tetrahedrite series (Pilou), and in enargite. $\mathrm{Sn}$ is mineralogically expressed as cassiterite, kesterite, mawsonite and stannoidite. Bi-bearing minerals have been identified in two $\mathrm{Cu} \mathrm{Pb}$ Bi-sulphosalts at $\mathrm{Ao}$ and as phases from the bismuthiniteaikinite series at Ballade. Tellurures as hessite and tetradymite are mentioned at Balade. $\mathrm{Ni}$-Co bearing sulphides like mackinawite and cobaltite are reported in Ballade and Fern Hill (BRGM 1987a; Maurizot 1981; Maurizot et al. 1989).

Deposits share the complex and polyphase deformation and metamorphism of their host rocks. The Diahot Terrane rocks have been subducted at depths of c. $50 \mathrm{~km}\left(1.7 \mathrm{GPa}-550^{\circ} \mathrm{C}\right)$. The protoliths display well developed penetrative foliation and stretching lineation. This lineation is related to the exhumation of the protolith with an almost constant NE-SW trend (Clarke et al. 1997; Cluzel et al. 1995). Sulphides display a general increase in grain size which parallels that of the silicates in the enclosing host rocks (Briggs 1975; Briggs et al. 1978). Most of the deposits are highly folded, stretched, and boudinaged. On the SW bank of the Diahot River the initially stratiform deposits are isoclinally folded and the main mined ore bodies are lenses or in thickened hinges (e.g. Pilou, Meretrice). On the NE bank of the Diahot River, in the high grade metamorphic zone, the mineralization zones are mainly controlled by the stretching lineation as elongated columns (e.g. Fern Hill, Balade). Where deformation has contributed to local thickening of mineralization, it however results in difficulty in laterally tracing the orebodies. 


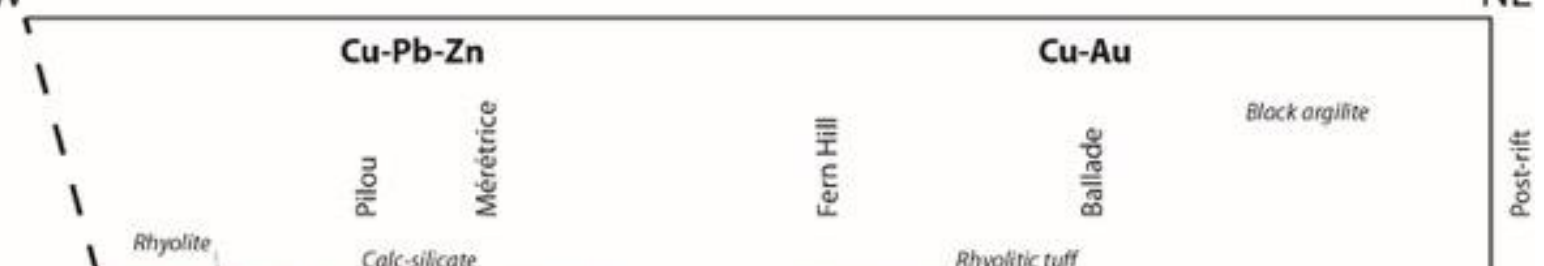

Basinal position: Proximal

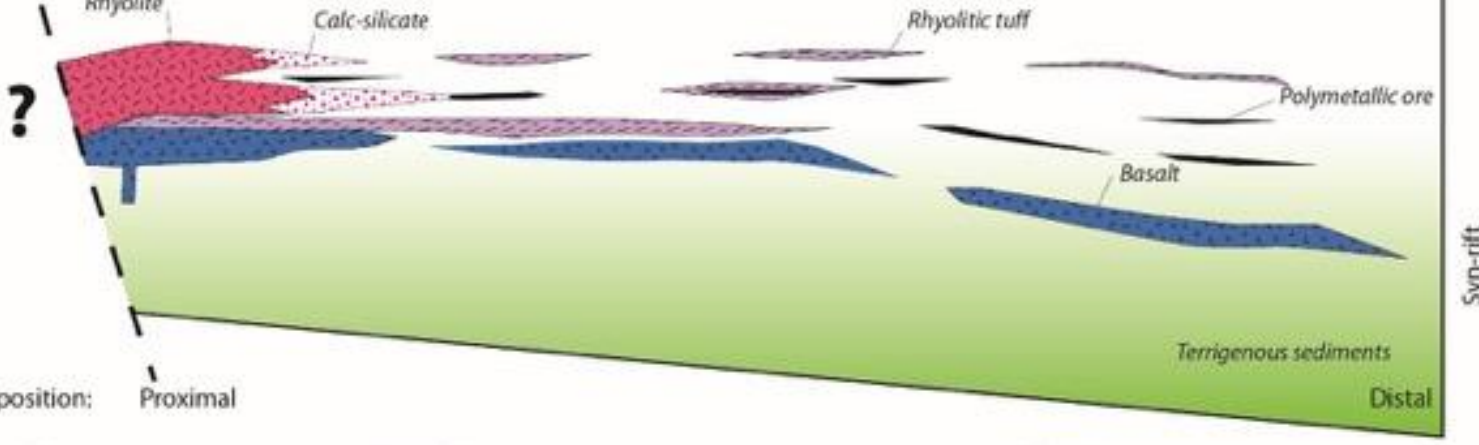

Metamorphism:

Blueschist

Deformation:

Foliation control

Fig. 5 Original basinal control of the Diahot deposits.

\section{Genetic model}

Deposits of the Diahot Basin correspond to the sedimentary-exhalative (SEDEX) stratiform sulphide type (Carne \& Cathro 1982; Klau \& Large 1980; Large 1980; Large 1992). Some sulphide lenses are clearly in continuity with metavolcanic rocks. The abundance of disseminated sulphides within many acidic meta-tuffs or -flows suggests a close genetic relation with that rock type. The absence of any mineralization associated with the meta-basaltic rocks discount them as source rocks, although their geographic extent is similar to that of the deposits.

Despite severe deformation and recrystallization, the distribution of deposits from SW to NE seems to reflect some original organization and structure in the sedimentary basin (Maurizot et al. 1989) (Fig. 5). The deposits to the SW of the Diahot River (Pilou, Mérétrice, and subsequent minor deposits) in the blueschist zone are associated with a regionally mappable complex of meta-rhyolite, meta-tuffs, and calc-silicate layers which in turn continue into layered orebodies. The deposits are in sharp contact with their blackschist host rocks and form a few solid sulphide-rich layers. The deposits are $\mathrm{Cu}, \mathrm{Pb}$, and $\mathrm{Zn}$-rich. To the NE of the Diahot River, in the eclogite zone, acidic volcanic rocks are represented by meta-tuff (Fern Hill) or are lacking (Ballade). Individual high grade deposits are present in an envelope of low grade disseminated ore with a typical hydrothermal mineralogic fingerprint. Dominant metals are $\mathrm{Cu}$ and $\mathrm{Au}$.

The above relationships suggest that the Diahot Basin deposits formed in a NW-SE half graben with a border fault close to the SW of the Pilou-Meretrice alignment that controlled acidic volcanic eruptive centres. In this proximal context, deposits are closely related to acidic volcanic centres. To the NE, deposits are likely in a deeper part of the basin, away from volcanic centres. In these distal locations, mineralizing hydrothermal fluids were more diluted. This configuration led to a zonation in term of type and metal deposit.

In the SEDEX model, deposits are usually enclosed in intracratonic or epicratonic extensional faultbounded rift basins and half grabens developed by extension along continental margins, a context which is consistent with the interpretaion of the Diahot Terrane as the northern thinned and rifted 
margin of the Norfolk Ridge of Zealandia (Clarke et al. 1997; Cluzel et al. 2001). The permeable syn-rift terrigenous sedimentary rocks play the role of reservoir leached by hydrothermal circulation systems related to volcanic activity. In the post-rift overlying less-permeable carbonaceous black shales, deposited in an anoxic, reducing, and starved environment, metals are precipitated as sulphides on the seafloor by reaction with the overlying reducing seawater column. If the role of the volcanism as a heat source generating fluid circulation seems clear, the part played by the acidic volcanism, closely associated with sulphides and metals (as compared with the mafic compositions which are barren of any mineralization) remains unclear.

Worldwide, SEDEX deposits are generally restricted to second and third order subbasins (Large 1980; Large 1992), a fact that is consistent with the small extent of the Diahot metallogenic province in the more widespread Late Cretaceous co-eval sedimentary unit of the Diahot Terrane (Fig. 3a). Globally, SEDEX deposits are an important resource for $\mathrm{Zn}$ and $\mathrm{Pb}$ and account for, respectively, more than $50 \%$ and $60 \%$ of the world's reserves of these elements (Tikkanen 1986). Economic deposits of this type of deposit have worldwide a median tonnage of $15 \mathrm{Mt}$. The Diahot Basin deposits, with a maximum inferred reserve of c. $100000 \mathrm{t}$ for a few mines, represent a very minor and, at present, non-economic resource.

\section{Adio Limestone}

A small manganese deposit is hosted by the basal conglomerate of the Paleocene Adio Limestone (Maurizot 2013) which unconformably overlies the schists of the Boghen basement terrane (Fig. 2). Manganese minerals occur in elongated and isolated clusters by replacement of the matrix and clasts of the conglomerate, particularly in the coarser facies. Mn impregnation increases towards the base of the conglomerate until it forms a continuous layer where pseudomorphing is complete (Avias \& Routhier 1962). $1220 \mathrm{t}$ of ore have been extracted from a small surface quarry at an average grade of $48 \mathrm{wt} \% \mathrm{Mn}$. When compared to the manganese deposits of the Poya Terrane, the $\mathrm{SiO}_{2}$ content is low (3\%).

This single representative of the manganese sedimentary deposit type (Dill 2010) is not related to any volcanic source. It is likely associated with the weathering of a continental land mass and has been deposited at the base of a transgressing shallow marine limestone.

\section{Post-obduction magmatism}

Two post-obduction km-size granodioritic calc-alkaline plutons intrude the Peridotite Nappe and its autochthonous substrate (Fig. 6), in the Massif du Sud. U-Pb dating of magmatic zircons gave ages of 27.5 Ma for Saint Louis granodiorite, near Noumea, and $24 \mathrm{Ma}$ for the Koum adamellite on the eastern coast, i.e. Late Oligocene (Cluzel et al. 2005; Paquette \& Cluzel 2007). Both granodiorites are composed of a main ellipsoid pluton and a stock of peripheral comagmatic dykes. Although some dykes of the Saint Louis pluton clearly intrude various rocks of the autochthonous substrate (Late Cretaceous to Eocene sedimentary cover) and display contact metamorphism with it, the bulk of the granodiorite is enclosed in the ultramafic rocks where it is associated with large serpentinised dislocation zones including the basal thrust sole of the Peridotite Nappe.

Within the ultramafic rocks, plutons and related dykes are associated with extensive hydrothermalised zones of silicification and carbonitisation, locally named "silica wall", which actually correspond to "listwanite", a term first coined by Rose (Rose 1837), or its synonym "silica-carbonate" (Buckman \& Ashley 2010), a term that prevail in the English-speaking countries. Carbonatization (ferroan-dolomite, 
ankerite, magnesite) and silicification (quartz) of the serpentinite host-rock is generated by $\mathrm{CO}_{2}-\mathrm{SiO}_{2}$ - $\mathrm{H}_{2} \mathrm{O}$ hydrothermal fluid. Relict minerals from the ultramafic host rock such as chromite are diagnostic.

In the Massif du Sud, silica-carbonates (listwanites) form important vein zones, in close association with the granodioritic plutons or away from them, either in the basal serpentinised thrust sole of the Peridotite Nappe, or in serpentinite slivers in the autochthon. Both granodiorite and listwanite have significant anomalous concentrations of $\mathrm{As}, \mathrm{Au}, \mathrm{Sb}, \mathrm{Hg}$, and $\mathrm{W}$, in contrast with the ultramafic host rock which is almost devoid of these elements. In the area between Thio and Nakety, listwanites have erratic but significant contents of As (500 to 1000 ppm), Sb (35 to 300 ppm), W (20 to 300 ppm), and less frequently in Au (> 100 ppb) (Aye et al. 1986; Aye \& Jacob 1983; Jacob 1985).

Gold has been actively prospected in the area of the Saint Louis and Koum plutons by the Mineral Resources Survey programme (BRGM 1987b, 1988, 1990a, b, c, d) although no economic target has yet been identified. Antimony, as stibnite lodes, has been mined in the area of Nakety on the east coast at the end of the 19th century. The main characteristics of the different deposits are summarized in table 2 .

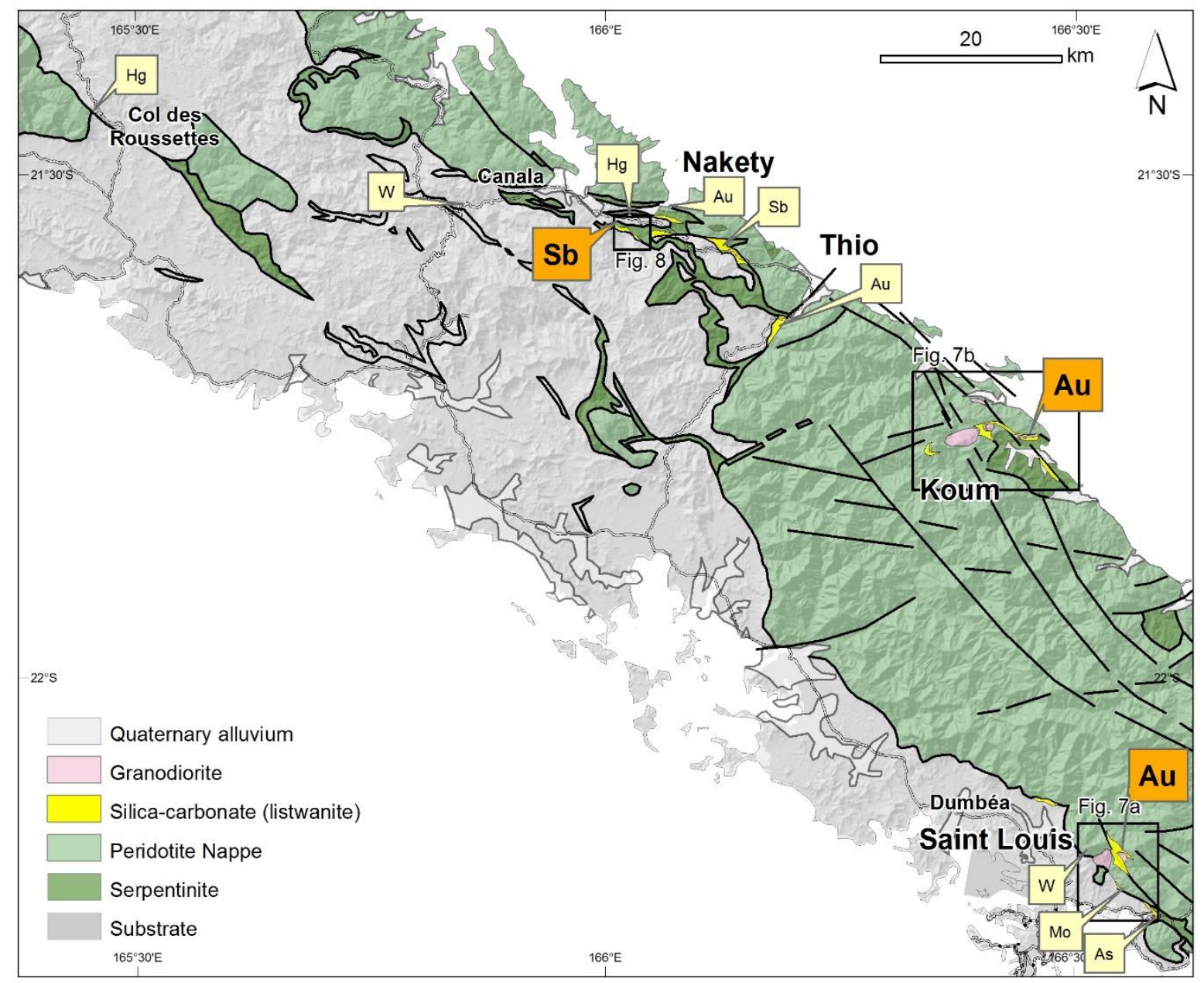

Fig. 6 Simplified geological map showing the principal features of the $\mathrm{As}, \mathrm{Au}, \mathrm{Sb}, \mathrm{Hg}, \mathrm{W}$ mineralizations associated with granodioritic post-obduction intrusions and silica-carbonate (listwanite). Small yellow labels: showings; Orange labels: deposits. 


\begin{tabular}{ccccccc}
\hline Name & $\begin{array}{c}\text { Major } \\
\text { element(s) }\end{array}$ & $\begin{array}{c}\text { Minor } \\
\text { elements }\end{array}$ & $\begin{array}{c}\text { Main } \\
\text { minerals }\end{array}$ & Alteration & $\begin{array}{c}\text { Production } \\
(\mathbf{t})\end{array}$ & Reserve \\
\hline Nakety & $\mathrm{Sb}(\mathrm{Au})$ & $\mathrm{As}, \mathrm{Hg}$ & $\begin{array}{c}\text { Stibnite } \\
\text { Arsenopyrite }\end{array}$ & $\begin{array}{c}1500 \mathrm{t} \text { at } 25 \\
\% \mathrm{Sb}\end{array}$ & $\begin{array}{c}2500 \mathrm{t} \text { at } 10 \% \\
\mathrm{Sb} \\
500 \mathrm{~kg} \mathrm{Au} \text { at } 3 \\
\mathrm{~g} / \mathrm{t}\end{array}$ \\
$\begin{array}{c}\text { Koum } \\
\text { D1 }\end{array}$ & $\mathrm{Au}$ & $\begin{array}{c}\mathrm{As}, \mathrm{W}, \mathrm{Bi}, \\
\mathrm{BM}\end{array}$ & Arsenopyrite \\
$\begin{array}{c}\text { Saint } \\
\text { Louis }\end{array}$ & $\mathrm{Au}$ & $\begin{array}{c}\mathrm{As}, \mathrm{Li}, \mathrm{W}, \mathrm{Mo}, \\
\mathrm{Bi}, \mathrm{Te} \mathrm{BM}, \mathrm{Sb}\end{array}$ & Arsenopyrite & $\mathrm{B}, \mathrm{Si}$ & $\begin{array}{c}\mathrm{t} \mathrm{t} \mathrm{Au} \mathrm{at} 0.1 \mathrm{~g} / \mathrm{t} \\
\mathrm{Au}\end{array}$ \\
\hline
\end{tabular}

Table 2 Summary of metallogenic and economic data of the main deposits of the As, Au, Sb post-obduction mineralization. $\mathrm{BM}$ : base metals $(\mathrm{Cu}, \mathrm{Pb}, \mathrm{Zn})$.

\section{Koum gold deposit}

Koum pluton (Fig. 7b) is intrusive into a disrupted zone of the Peridotite Nappe which runs parallel to the east coast, associated with a large serpentinite area. The regional fracture pattern in the ultramafic host rock is composed of two conjugate sets with dominant dextral NW-SE and subordinate sinistral NE-SW strike-slip faults. Anomalous As and Au contents were discovered in E-W striking dykes (Koum D1) to the east of Grand Koum pluton during the Mineral Resource Survey programme (BRGM 1980).

The Koum D1 dyke is a $2.2 \mathrm{~km}$ long structure with a maximum width of $300 \mathrm{~m}$ (Fig. 7c). It was actively prospected from 1980 to 1987 by the Mineral Resources Survey programme (BRGM 1987b), then by different junior companies from 1989 to 1998. Methods used were soil geochemistry, alluvial concentrates, groove sampling along trenches, auger sampling, and core drillings. The D1 structure is a complex assemblage of listwanite and granodiorite. Among several facies, porphyritic microgranite with quartz and feldspar phenocrysts and microgranite with sericite are the most common. There is no evidence of any preferred orientation fabric in the granodiorite which usually displays an equigranular texture. To the west, the E-W trend of D1 displays obvious dextral offsets; however the granodiorite in these areas does not show any correlative brittle or ductile deformation, a fact that is indicative of a post-fault intrusion. Silico-carbonates (listwanites) are dominant in the wall of the D1 structure/dyke but may also be found as inclusions within the granodiorite. Granodiorite-silicocarbonate relationships are very complex in detail but the contact is always sharp and clearly intrusive.

Secondary alteration phases are always present in the granodiorite and consist of muscovite, sericite, chlorite, albite, ferroan and magnesian carbonates (ankerite, breunnerite, dolomite), quartz, silica, and sulphides. Sulphides are disseminated within the granite or in quartz veinlets. They are represented by pyrite, arsenopyrite, minerals from the tennantite-tetrahedrite series, chalcopyrite, sphalerite, jamesonite, and pyrrhotite. This assemblage is typical of granite beresitisation (Rose 1837), a lowtemperature metasomatic alteration associated with a variety of gold bearing deposits in acidic igneous rocks, and a term commonly used in Russian literature. Silico-carbonate (listwanite) is considered as the result of beresitisation process in ultrabasic rocks (Zharikov et al. 2007). The listwanite-granitoid-beresite association is commonly referenced in the Ural goldfields (e.g. Berezovsk goldfield, type locality of listwanite) and in other Russian auriferous districts (Baksheev et al. 1999; Laznicka 2006; Likhoidov et al. 2007). 
Rocks are highly weathered with thick laterite development on ultramafic rocks. Granodiorite is rarely fresh, and usually is transformed to grit or quartz sand down to $40 \mathrm{~m}$ depth (BRGM 1987b, c).
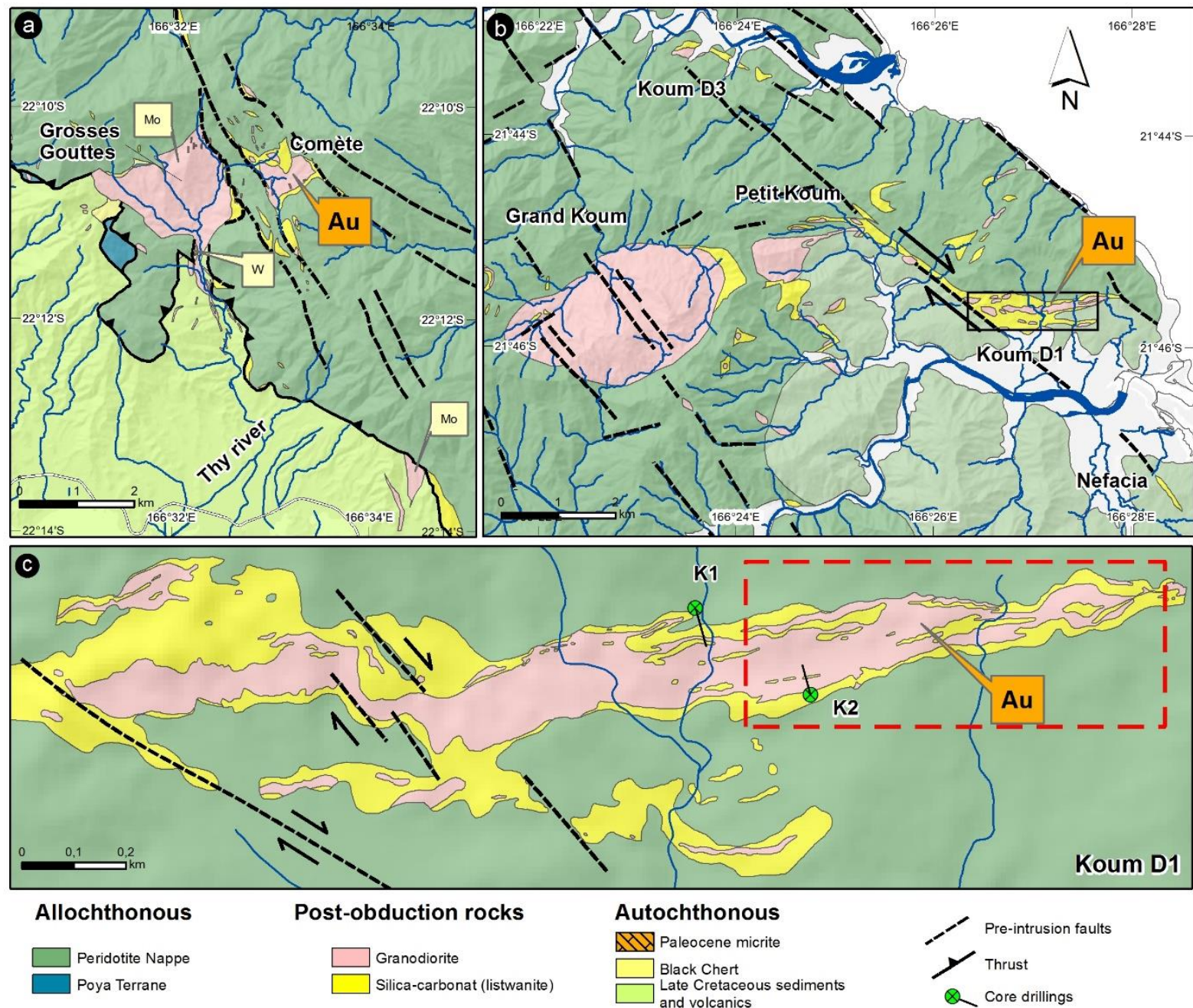

Fig. 7 Geological maps of Saint Louis and Koum (same scale) post-obduction granodiorites with associated mineralisations. a) Saint Louis geological maps showing the complex relationship of the granodiorite with both authochtonous substrate and allochthonous Poya Terrane and Peridotite Nappe. b) Koum geological map. c) Detailed map of Koum D1 gold prospect; dashed red rectangle encloses the area with 2 ppm Au average content.

Gold was never recovered in alluvial concentrates and free gold grains are never observed in polished thin sections. Instead, gold is apparently chemically bound within arsenopyrite. In Koum D1 dyke, gold anomalies are located mainly near the many contacts between granodiorite and listwanite either on both edges of the dyke or inside silica-carbonate (listwanite) lenses in the dyke. Au has a high variability from 10 to several $1000 \mathrm{ppb}$ in listwanite. Up to $14 \mathrm{ppm}$ Au content was found repeatedly in listvwanite. Au content of granodiorite is $100 \mathrm{ppb}$ in average, and the $100 \mathrm{ppb}$ Au isopleth corresponds roughly to the granodiorite margins. The $800 \mathrm{ppb} A u$ isopleth coincides with most of the granodioritelistwanite contacts. On the whole, Au content increases within the granodiorite towards the listwanite wall rock with values often higher than $10 \mathrm{ppm}$. At a larger scale, Au content increases towards the east where the granite pinches out. In this area, over a length of $500 \mathrm{~m}$, the average content of soil samples is c. $2 \mathrm{ppm}$ Au. In places, decametric long and narrow large metre-scale veins, reach a content of 5 to $10 \mathrm{ppm}$. A maximum content of $50 \mathrm{ppm}$ Au was locally found in auger sampling. Beside this primary lithologic control, a supergene gold enrichment is marked in many drill cores by a depletion of 
the average gold grade with depth. Au is correlated with $\mathrm{Sb}, \mathrm{As}, \mathrm{K}, \mathrm{W}, \mathrm{Bi}$, and $\mathrm{Pb}$. $\mathrm{Au}, \mathrm{As}, \mathrm{Sb}$, and $\mathrm{W}$ are present in the listwanite. Au is not detected in the ultramafic host rock ( $<3 \mathrm{ppb})$, whilst $\mathrm{As}, \mathrm{Sb}$, and $\mathrm{W}$, are sporadically in significant amount (BRGM 1987b).

Rolling bottle cyanuration tests indicate a possible recovery of 90 to $99 \%$ of the gold. The gold content of the whole Koum D1 structure has been roughly estimated at $9 \mathrm{t}$ of metal for a down dip extent of $100 \mathrm{~m}$ and a cut-off grade of $0.1 \mathrm{ppm}$. The rock being weathered to a depth of 20-40 m, it could be partly extracted in an open pit and processed by heap leaching (BRGM 1987b).

The overall succession of events in the Koum area can be summarized as follow: i) NW-SE dextral transpressive faulting and correlative pull-apart opening of conjugate NE-SW structures in the peridotite. ii) Hydrothermalism of host ultramafic rock as silica-carbonate (listwanite), which are precursor of the granite and are offset by dextral strike slip faults. iii) Passive intruding of the granite in the pre-fractured peridotite and listwanite (which are found as inclusions within granite). iv) Hydrothermalism of the granite and to a lesser extent of the listwanite with sulphide impregnation.

As well as the listwanite-granitoid-beresite model, the Koum D1 deposit may be compared to other intrusion-related gold systems (IRGS; Lang et al. 2000), a low-grade, large-tonnage, postdeformational, granite-hosted gold deposit model.

\section{Saint Louis gold deposit}

The Saint Louis pluton is a hornblende-biotite granodiorite with numerous subvolcanic dykes and comagmatic enclaves (Cluzel et al. 2005; Lemennicier et al., 1998, 1999; Paquette \& Cluzel 2007). The main Grosses Gouttes batholith is deeply eroded by the Thy River (Fig. 7a). The smaller Comète intrusion, to the NE, is separated from the Saint Louis intrusion by a major transcurrent dextral fault zone. It corresponds to a more apical subvolcanic part of the pluton, covered with thick colluvium and weathering products, and surrounded by silica-carbonate (listwanite). Litswanite occurrences are controlled by fault zones.

Gold flakes, blebs and small nuggets, extracted by alluvial or eluvial wash on the current site of Comète, were reported at the beginning of European settlement (Glasser 1904). Two occurrences of molybdenite are known, in the Grosses Gouttes batholith, and in a separate dyke intruding the Late Cretaceous sedimentary rocks, $6 \mathrm{~km}$ to the SE of the granodiorite. At the southwestern contact of the Saint Louis pluton, Paleocene limestone is locally transformed to garnet and scheelite bearing skarn (Guillon \& Trescases 1976).

A regional prospectivity study undertaken by the Mineral Resources Survey programme, using sieved stream-sediments (BRGM 1980) highlighted several geochemical anomalies in As, W and Au (40 to 80 $\mathrm{ppb} \mathrm{Au}$ ) in the Comète watershed. A subsequent exploration campaign included soil geochemistry, alluvial concentrates, trenches, auger sampling, and core drilling (BRGM 1986a, 1987c). The higher Au contents, in soil and rock, are centered on the granitic part of Cométe pluton rather than the surrounding listwanite.

Mineralization is hosted exclusively in quartz veined, sulphide bearing, and hydrothermally altered granite, with K-feldspar and phengite pseudomorphs after plagioclase, biotite and hornblende. In the high grade alteration zones, the granite is proto-mylonitized and brecciated. The main hydrothermally altered zones and quartz veins trend in a NS direction. Mineralisation is composed of pyrrhotite, pyrite 
and marcasite with epitaxic arsenopyrite (with up to $0.1 \%$ Au content), chalcopyrite with sphalerite exsolutions, minerals from the tenantite-terahedrite series, molybdenite with telluro-bismuthinite inclusions, scheelite, rare native gold, tetradymite, rutile, and leucoxene (BRGM 1986a, 1987c).

Three main anomalies are distinguished inside an area of average $100 \mathrm{ppb}$ Au content, within which, isolated values of $1 \mathrm{ppm}$ Au occur. The largest mineralized zone is $500 \mathrm{~m}$ long and $50 \mathrm{~m}$ wide. At depth it has been traced down to $30 \mathrm{~m}$ by drilling. These zones are characterized by numerous quartz veins in a granitic saprolite. The drilling has crosscut decimetre to metre-size lengths of veined granite with 1 to $10 \mathrm{ppm}$ Au. One rock sample of silicified granite with disseminated sulphides yielded a maximum content of 20 ppm Au. Au content has a high variability. Au, As, Li, K, Si, W, Cu, Zn and Sb are correlated.

As in the case of Koum granodiorite, supergene gold enrichment is shown by depletion of the average gold grade with depth in drill core. The Comète intrusive body, deeply weathered, forms a modern geomorphic basin whose outlet is blocked to the SW by a NW-SE trending listwanite bar. This particular topography favored the colluvial accumulation of residual fragments of quartz veins and gold nuggets upstream in the Comète basin that led to the early discovery of the prospect.

The Saint Louis gold potential is less important than Koum. So, therefore, is its economic interest. The nature of both deposits differ significantly in term of sulphide mineralogy, geochemistry, alteration, gold content, and host rock (Table 2). The Saint Louis gold deposit corresponds to the plutonic porphyry gold deposit model (Sillitoe 2010) a well-known large tonnage, low-grade type of resource, associated with shallow intrusions, with pervasive potassic or phyllic alteration, and the association of $\mathrm{Au}, \mathrm{Bi}, \mathrm{W}$, and Mo. However, with only $0.5 \mathrm{~km}^{2}$, it is far from having the size and metal content of the economic standard porphyry gold deposits which are in the range of 25 to $100 \mathrm{~km}^{2}$.

\section{Nakety antimony deposit}

The Nakéty antimony deposit is the only significant occurrence of this metal recognized to date in New Caledonia. It is of lode type and contains gold as well.

The earliest works of the Nakety antimony mine date back to 1879. The operation itself (several hundred metres of underground works) lasted only three years (1883-1885). This work extracted 1500 $\mathrm{t}$ of ore at a grade of about $25 \mathrm{wt} \% \mathrm{Sb}$. Since then and until 1982, when the Mineral Resources Survey programme tried to reassess the deposit (soil geochemistry, geophysics, trenches, and c. $900 \mathrm{~m}$ of core drillings, Aye et al. 1986; Aye \& Jacob 1983; BRGM 1986a; Chiron et al. 1986; Jacob 1985), no substantial work, exploration or development, took place.

The deposit is hosted by a c. $100 \mathrm{~m}$ thick sliver of Late Cretaceous black shales and cherts from the Montagne Blanche Nappe, heavily sheared inbetween overlying serpentinite slices connected to the basal sole of the Peridotite Nappe, and underlying Mesozoic greywackes of the Central Terrane. Serpentinite is often altered into silica-carbonate (listwanite). The deposit is in the form of a discontinuous, roughly en echelon, vein system, which extends over a length of $1250 \mathrm{~m}$ (Fig. 8). Most of the veins are hosted within the Late Cretaceous shales but some of them crosscut the basal greywackes. Individual stibnite veins extend over c. $100 \mathrm{~m}$ in length for a thickness of 0.1 to $3 \mathrm{~m}$, and have been crosscut by drilling down dip to c. $100 \mathrm{~m}$.

Complex brecciation and filling of the dykes indicate a multiphase process under variable tectonic conditions. Two major hydrothermal phases with two different types of quartz veins are reported 
(Chiron et al. 1986): i) an early network of oxidized gold bearing quartz veins, with very little antimony; ii) a late network of pure white quartz veins, with or without stibnite. Stibnite distribution is discontinuous and irregular, either disseminated or massive. Massive stibnite is generally restricted to the footwall of the dykes, filling voids, in a clearly extensional context. Quartz is the usual gangue mineral, sometimes with barite, but small pockets of stibnite may occur directly in the sedimentary host rock.

The mineral paragenesis is simple and can be summarized in essence as stibnite and arsenopyrite. Gold and antimony mineralization is relatively independent, thus agreeing with the observation of two specific quartz vein generations. The gold content of the ore is from 2 to $5 \mathrm{ppm}$ in average. The highest gold values are associated with high values of arsenic and low values of antimony. The gold is partly related to arsenopyrite whose earlier deposition relative to stibnite is microscopally observed. Gold is never observed macroscopically or in polished section. Accessory or rare mineral phases are pyrite, sphalerite, scheelite, cinnabar, and galena. Reserves for a down dip extent of $100 \mathrm{~m}$ are estimated to $2500 \mathrm{t}$ at $10 \% \mathrm{Sb}$ and $500 \mathrm{~kg}$ Au at 3 ppm cutoff (BRGM 1986b).

The Nakety Sb-lode can be classified as a structure-bound antimony deposit type (Dill 2010) which is typically shear zone-hosted, in the mesothermal field, in a distal position relative to a heat zone, with a limited mineralogy made up chiefly of stibnite. 


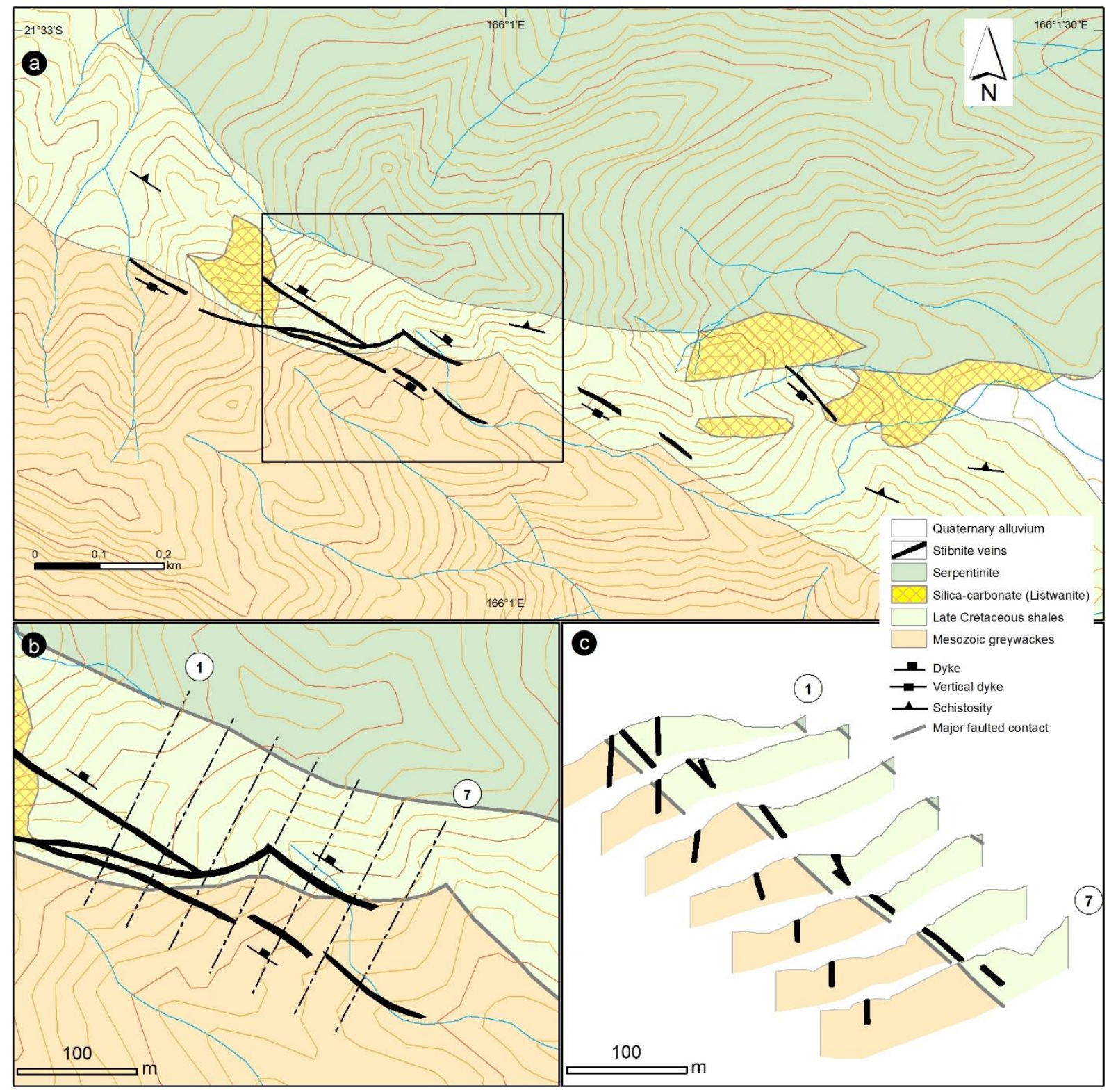

Fig. 8 a-b) Geological maps and c) cross sections of the Nakéty antimony deposit.

\section{Other occurrences}

A number of small, scattered showings of $\mathrm{Au}, \mathrm{Sb}, \mathrm{W}$, and $\mathrm{Hg}$ are associated with the main silicacarbonate (listwanite) lenses or major regional fault zones in a variety of formations (Fig. 6). Their mineralogy includes arsenopyrite, cinnabar, realgar, and scheelite. Only the significant ones are briefly described below.

To the east of Canala, scheelite, cinnabar, and datolite $\left(\mathrm{CaBSiO}{ }_{4} \mathrm{OH}\right)$ are associated in small quartzcarbonate veins crosscutting the Boghen Terrane (Glasser 1904).

The mercury deposit of Col des Roussettes has been known since 1893 and has been prospected at different periods (Maurizot 1981). The mineralisation forms irregular coatings and veinlets in fractures and joints of a highly sheared fault zone underlying the Mé Maoya peridotite klippe. The recognisable host rocks include mica schists of the Boghen Terranne and the calcareous Eocene Flysch. The $\mathrm{Hg}$ and Au contents are generally low and erratic. Maximum reported contents are of $2.5 \mathrm{wt} \% \mathrm{Hg}$ and $2 \mathrm{ppm}$ 
Au. Mineral carriers are cinnabar and droplets of native mercury. Reserve has been assessed to 400 $000 \mathrm{t}$ of ore at $0.5 \mathrm{wt} \% \mathrm{Hg}$ (Colleau et al. 1978). These $\mathrm{Hg}$ occurences corresponds to the Californiatype cinnabar deposits (Laznicka 2006), connected to a serpentinite fault zone, but hosted in sedimentary rocks, especially those rich in carbon, more prone to entrap it.

\section{Genetic model}

Silica-carbonates (listwanites) worldwide, are associated with the emplacement of late-orogenic granitic rocks (Likhoidov et al. 2007). They commonly host the As, Au, Sb, W, Hg association (Buisson \& Leblanc 1986; Goncharenko 1970; Halls \& Zhao 1995; Laznicka 2006). In this association, Hg has a more independent behaviour, being often disconnected from the main crustal scale discontinuities.

In New Caledonia, listwanite and granodiorite are two cogenetic hydrothermal and magmatic expressions of post-obduction events. Emplacement of plutons and surrounding listwanites is controlled by the post-obduction steeply dipping pre-existing fault pattern at the mine scale, and by the contact between allochthonous serpentinized basal sole of the Peridotite Nappe and autochthonous substrate at a regional scale. Granitoids and listwanites are present only in the Massif du Sud and its east coast extension, never in other ultramafic units located farther north.

Litswanites and intrusives form an original metallogenic provinces involving three deposits with Au and $\mathrm{Sb}$ which have had or may have an economic interest. $\mathrm{Au}$ is the common element to these three deposits. Au is mainly associated with intrusives while $\mathrm{Sb}$ is always related to silica-carbonate (listwanite). Other accompanying and accessory elements are $\mathrm{W}, \mathrm{Mo}, \mathrm{Bi}$, and base metals. $\mathrm{Hg}$ is distal from granitoids and often unrelated with listwanites. Saint Louis granite has a distinct association in Mo, Li, and Te. Both Saint Louis and Koum plutons display the same spatial arrangement with a main roughly elliptic plutons to the west and smaller mineralized satellites and apophyses to the east.

A more detailed analysis allows the differentiation of several types of mineralization and settings related to the obduction event.

The Late Oligocene plutons were first interpreted as a product of the melting of the underlying continental crust (i.e. the Norfolk Ridge, Rodgers 1973, 1976). However an origin in an active margin setting has been more recently proposed (Cluzel et al. 2005) on the grounds of isotopic geochemical data. In this model, after the blocking of the Late Eocene subduction zone by the continental Norfolk Ridge, the Saint Louis intrusion (27 Ma) resulted from the onset of a new short lived NE dipping subduction along the SW coast generating active margin magma. In this model, the younger Koum intrusion (24 Ma) resulted from the break-off of the older slab (Sevin et al. 2014), leading to the formation of a slab window, asthenosphere upwell, thermal perturbation, and melting of the overriding plate. This two stage intrusion model is consistent with the two types of gold deposits associated with the post-obduction granitoids. The synorogenic porphyry type Saint Louis deposit, is compatible with an intrusion generated in the overriding plate by active subduction. Its modest size accounts for a short lived period of subduction. The rapid exhumation and weathering of the pluton, dated at c. $18 \mathrm{Ma}$ by $\mathrm{K} / \mathrm{Ar}$ on Mn oxide (Bailly et al. 2014), is also consistent with a shallow emplacement that fits the typical porphyry deposit model (commonly in the range of 1-5 km depth, Sillitoe 2010). The younger Koum pluton intruded the Peridotite Nappe in a different and more passive context. There, the associated gold deposit is essentially fault-controlled. 
The New Caledonia silica-carbonates (listwanites) are both precursors and distal expressions of the hydrothermal alteration associated with the post-obduction intrusions. Listwanite occurrences may be located quite far from granites (Nakéty Sb deposits is at $45 \mathrm{~km}$ from Koum granodiorite) but their majority is either closely associated and in contact with plutons or in the basal thrust contact of the Peridotite Nappe. Some listwanites are sterile (e.g. Dumbéa, Fig. 6) but most have an anomalous geochemical background in $\mathrm{As}, \mathrm{Au}, \mathrm{Sb}, \mathrm{W}$, and $\mathrm{Hg}$.

\section{Uncertain type}

An unusual group of small copper deposits is located in the Massif du Sud at Pic Casse Cou (Guillon 1972). It consists of five lenses of 0.5 to $1.2 \mathrm{~m}$ in thickness, c. $10 \mathrm{~m}$ in length, associated with a serpentinite shear zone. The shear zone crosscuts dunite below the cumulate sequence of Montagne des Sources. The ore is composed of magnetite and chalcopyrite with c. $10 \mathrm{wt} \% \mathrm{Cu}$. A few tons were extracted in 1920. This occurrence might be related to the many dykes (Cluzel et al. 2006) crosscutting the Peridotite Nappe which are however usually devoid of such copper mineralisation.

\section{Offshore metallic mineral resources}

Although there has yet to be any actual economic exploitation, deep sea metallic mineral resources (polymetallic nodules, ferro-manganese crusts, and massive sulphide deposits) have attracted perennial attention around the world and particularly in the SW Pacific area. Some area of the New Caledonia EEZ could be favourable for the formation and preservation of such deep sea resources.

Polymetallic nodules are generally found in deep abyssal plains where sedimentation rates are very low. Such conditions are thought to be present in the D'Entrecasteaux Basin and possibly the North Loyalty and South Fiji basins. However only a few nodules have been dredged in the EEZ of New Caledonia, and they were found not in the abyssal plain but, fortuitously, on seamounts and ridges (D’Entrecasteaux and Loyalty ridges, Laurent 2011).

Ferro-manganese crusts develop at depth below $400 \mathrm{~m}$ on hard surfaces sheltered from the pelagic sedimentation (Fouquet \& Lacroix 2012). They are generally found on ridges and seamounts where a combination of low sedimentation rates, steep slopes and currents prevent any accumulation of sediments. The seafloor of the EEZ of New Caledonia contains many such rises, ridges and seamounts (Pascal et al. 1992; Vanney et al. 1992). Centimetre thick ferro-manganese crust have been dredged along the Loyalty Ridge and near to the Récif d'Entrecasteaux (Lafoy et al. 1996), with a low content of $0.5 \%$ wt Co (Pichocki \& Hoffert 1987). A specific site, offshore NE from Tiga ( $20^{\circ} 47^{\prime} \mathrm{S}-167^{\circ} 31^{\prime} \mathrm{E}$, at 1400 $1700 \mathrm{~m}$ depth) has yielded ferro-manganese crusts with tiny inclusions of gold and silver (Bolton et al. 1986).

The uninhabited Matthew and Hunter volcanic islands, and the surrounding New Caledonia EEZ, belong geologically to the southeastern termination of the active New Hebrides subduction zone and volcanic arc (Fig. 9). Detailed bathymetric surveys (Patriat et al. 2015) show that back-arc extension of the North Fiji Basin is propagating southwestward into the arc in a rifted area characterized by numerous volcanic centres. Dredged samples show an uncommon diversity of fluids and magmas (Danyushevsky et al. 2006), known to be usually associated with massive sulphides deposits. 


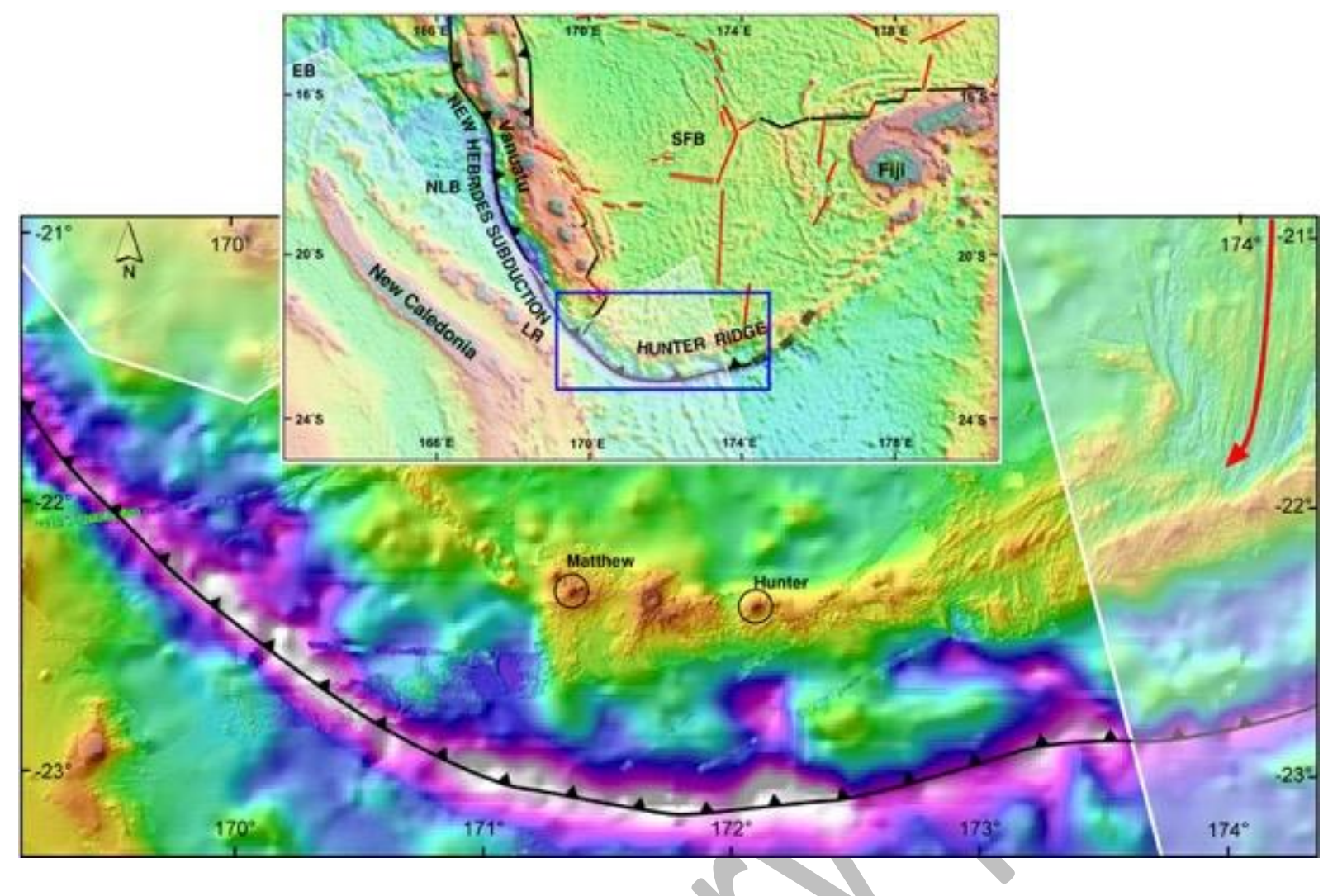

Fig. 9 Matthew and Hunter islands along with other volcanic structures forming an island arc, at the southeastern termination of the New Hebrides subduction zone. A N-S spreading ridge (thick red line with arrow) is visible in the NE, propagating to the SW into the arc. White line to the east and north: limits of the New Caledonia EEZ; EB: D’Entrecasteaux Basin; LR: Loyalty Ridge; NLB: North Loyalty Basin; NFB: North Fiji Basin. 


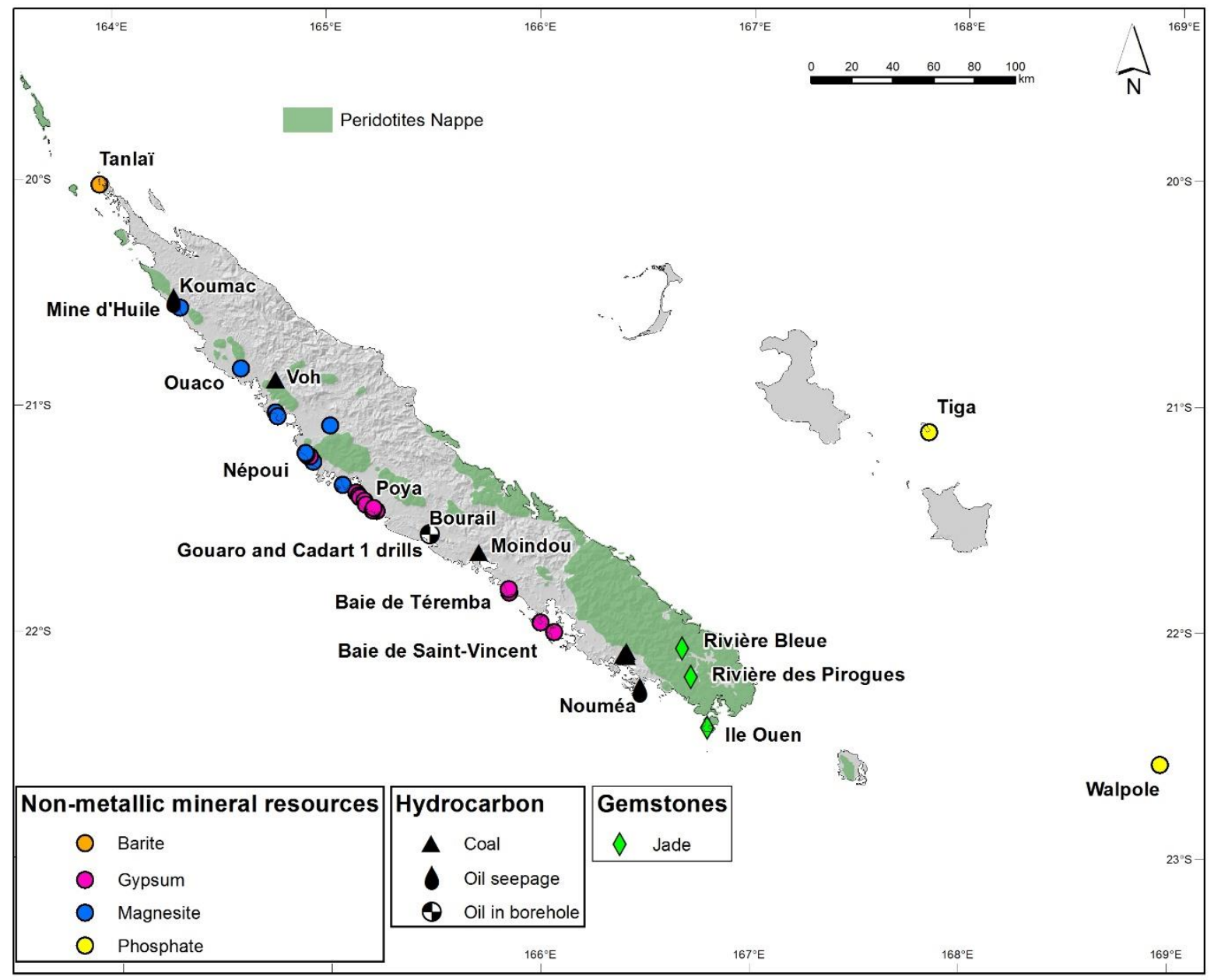

Fig. 10 Map of non metallic, hydrocarbon, and gemstone mineral resources of onshore New Caledonia.

\section{Magnesite}

Magnesite as nodules and cauliflower-shaped concretions, 10 to $50 \mathrm{~cm}$ in diameter, is often present in various post-obduction units along the west coast of New Caledonia. Magnesium leached from the ultramafic massifs precipitates as carbonate in many lithologies: Miocene Népoui sedimentary rocks (mainly conglomerates as clasts or in the matrix), serpentinites of the basal sole of the Peridotite Nappe, serpentinite slivers in the Poya Terrane, and magnesium-rich soils (vertisols). Sheared magnesite veins of meteoritic origin, according to oxygen isotopic composition, in the serpentinite sole of the Koniambo ultramafic massif, indicate that weathering was already active during obduction (Quesnel et al. 2013).

Magnesite deposits have been quarried and used locally in the nickel industry to change the Mg content of the ore and in the smelting process of Doniambo plant (Nouméa, cf. chapter 9, this memoir) as refractory (Lebret \& Maurizot 2007). From 1943 to 1968 the total production was 33500 t, of which 21000 t were extracted in the Népoui-Poya area and 12500 t near Koumac, at an average of 45 wt \% Mg with less than 3 wt \% Si. From 1955 to 1959, 15300 t of magnesite were exported to Australia (Broken Hill Proprietary). 
From an economic view point, magnesite deposits are presently of low importance as a source for either magnesium or carbonate. Today, a new scientific interest has arisen, to try to better understand naturally occurring carbonation reactions at near surface conditions, and their implications for engineered in situ $\mathrm{CO}_{2}$-sequestration processes by injection of $\mathrm{CO}_{2}$ bearing fluid in ultramafic and mafic lithologies (Kelemen \& Matter 2008).

\section{Gypsum}

In New Caledonia gypsum is known on the south western coast and islands of Baie de Saint Vincent. Inland or in the marshland area, gypsum is always associated with clays. Clays bearing gypsum were at first all interpreted as marine evaporitic deposits (Avias 1953; Gonord 1968; Piroutet 1917; Routhier 1953). Later on, a distinction was made between two different types of occurrences.

In the marshland tidal zone of Mara, near Baie de Téremba (Avias 1952; Baltzer 1965), gypsum occurs at a depth of 10 to $80 \mathrm{~cm}$. Crystals, as 1 to 10 centimetre long sticks or lenses, often twinned, are disseminated inside ferruginous clay. Their origin is still unclear. It could be either evaporitic or related to the weathering of sulphides of the bedrock (greywackes of the Téremba Terrane).

The majority of occurrences are actually located inland (up to $10 \mathrm{~km}$ ), at altitudes up to $160 \mathrm{~m}$ (e.g. top of Leprédour island), which preclude a marine origin. They are here associated with vertisol resulting from the tropical weathering of different sulphide bearing units, mainly basalts of the Poya Terrane, Eocene flysch, and Mesozoic greywackes of the basement (Beaudou et al. 1983; Latham et al. 1978; Tercinier 1963). Gypsum occurs in clay (mainly smectite) as disseminated centimetre petal shaped crystals or as large sand roses, and may constitute more than $50 \%$ of the volume of the host soil (Le Berre 1990b, 1991). Detailed studies have placed these occurrences in their pedogenetic and geomorphological context (Podwojewski 1988, 1992, 1993, 1994, 1995). Thick Ca- and Mg-rich vertisols are developed in low relief areas, mostly on hillside, where their thickness may reach $10 \mathrm{~m}$, and occasionally on alluvial formations, down to a depth of 0.8 to $1.5 \mathrm{~m}$. Carbonate (calcite, aragonite, magnesite) concretions are also present in the deposits. In Baie de Saint Vincent, the gypsum-bearing vertisols are capped or replaced uphill by caliche in a paleo-morphological continuum.

These deposits have been operated in many places as open cuts of c. $0.2 \mathrm{~km}^{2}$, for a depth of a few metres, mostly manually. From 1917 to 1954, c. 325000 t was produced solely for use in sulphuration in the nickel smelting process of the Doniambo plant.

The sulphur isotopic ratio ${ }^{34} \mathrm{~S} /{ }^{32} \mathrm{~S}$ was used as a tracer to identify the origin of the gypsum (Podwojewski 1994). This study found that the isotope ratio of the gypsum is clearly unrelated to the nature of the bedrock. There is a linear anti-correlation between the ratio values of gypsum in the vertisols and the distances from the coast. A dual origin for the sulphur of gypsum from the vertisols was therefore suggested. Near the shore, isotopic ratios are typical of sea water suggesting that a major fraction of sulphur is likely brought by sea spume penetrating the vertisols through cracks opened during the dry season. The ratios decrease inland at the expense of a minor continental source whose signature does correspond to the disseminated sulphur of the bedrock. Various $\mathrm{Ca}-\mathrm{Mg}$ nodules of the vertisols have been dated by ${ }^{14} \mathrm{C}$ methods. The main peak age between 15000 and $28000 \mathrm{yr}$ BP suggests that the majority of vertisols with gypsum was formed during the last glaciation, under a climate with contrasted seasons, with alternating dry and wet annual periods, and strong winds bringing sea spray (cf. chapter 7, this memoir). 
Barite

Barite nodules are often present in the Late Campanian to Maastrichtian Black Chert Formation of the Late Cretaceous post-rift cover. The barium content of the chert is everywhere abnormally high and commonly in excess of $1000 \mathrm{ppm}$ (Maurizot 2011), a fact that has been reported for the equivalent Whangai Formation, in New Zealand (300 to 10000 ppm Ba; Ballance 1993).

The only occurrence of barite that could be described as a deposit is located in the HP-LT Eocene metamorphic complex of the North of New Caledonia, on Tanlaï Island (Fig. 10), within the Black Chert Formation. Primary barite occurs in a vein stockwork, sometimes as millimetric to centimetric euhedral prismatic or cockscomb crystals, associated with quartz. Part of the deposit corresponds to a secondary concentration as colluvium. The overall deposit has been estimated to c. $50000 \mathrm{t}$ at $60 \%$ of $\mathrm{BaSO}_{4}$ and 40 \% $\mathrm{SiO}_{2}$ (Eberlé 1982; Espirat \& Millon 1971; Routhier 1953).

Barium as barite in the Black Chert formation is clearly strata-controlled at large scale as shown by its regional extent throughout New Caledonia and New Zealand in the same stratigraphic horizon. There is no contemporaneous volcanic activity. Occurrences are associated with anoxic, organic rich sedimentation during periods of minimal clastic input, typical of this period of post-rift thermal relaxation (Maurizot 2011). A sedimentary origin is therefore inferred. According to the model of Koski \& Hein (2003) barite precipitation is controlled by ocean circulation, biogenic productivity, and oxic/anoxic-water boundary. Barite dissolves in anoxic bottom waters and precipitates above the oxic/anoxic-water boundary along submarine slopes. Secondary controls might be necessary to reconcentrate barium in order to form higher grade economic deposits, e.g. faulting or folding in a metamorphic context (which is probably the case in Tanlaï Island deposit). As yet poorly investigated the interest for these minor barite deposits might be renewed by the possible occurrence of accompanying rare earth elements.

\section{Phosphate}

Phosphate is the only onland Loyalty Islands mineral resource of interest. The soils of Grande Terre being often magnesian-rich and carbonate-poor, due to the widespread occurrences of ultramafic lithologies, phosphate fertilizer has been massively imported in the past and the exploration of local sources has been accordingly encouraged.

Small scale phosphate occurrences filling karstic dissolution voids and fractures, are very common in the carbonate platform of the Loyalty Islands (Koch 1957a, 1958c). This feature contributes to the higher soil fertility of these islands as compare to Grande Terre. However, phosphate deposits of actual or potential economic interest are only known in Tiga, a small island located between Maré and Lifou, and Walpole, the southernmost emerged land of the Loyalty Ridge (Fig. 10).

The Tiga deposit was discovered during the 1950s. It has been carefully prospected and evaluated, but remains unexploited (Koch 1957b, 1958a, b; Obellianne 1958). Tiga is a $6 \times 2.5 \mathrm{~km}$ emerged ancient atoll with well preserved morphology, including an elevated crown representing the peripheral reef barrier rimming two stepped plateaus which represents the bottoms of the former lagoon. The phosphate deposit lies in the higher and easternmost plateau. Phosphate occurs as concretions and speleothem fillings and is associated with bioclastic and oolitic limestone. Phosphate lies in a number of karstic voids separated by pinnacles of limestone. Karstic voids are pockets, funnels, deep cylindrical chimneys with vertical walls, complex lobate pits corresponding to coalescent chimneys, and fracture controlled furrows, 2 to 10 metres deep. Most of void morphologies and alignments are fracture- 
controlled with a NW-SE direction. Two kinds of ore are distinguished. i) A bioclastic and oolitic limestone which is commonly a soft material that can be excavated manually. Its content is less than 55 wt $\% \mathrm{P}_{2} \mathrm{O}_{5}$ with a high variability. ii) $\mathrm{A}$ richer phosphate material comprising amorphous cryptocrystalline collophane nodules and grains mixed with pisoliths and ooliths, in a sandy iron and phosphate rich matrix, which fills the karstic voids. Fish teeth and turtle bones are common in this lithology. The grade is commonly over 70 wt $\% \mathrm{P}_{2} \mathrm{O}_{5}$.

The ore grade increases toward the center of the Tiga eastern plateau. The reserve, considering the soft material, are of 350000 to $400000 \mathrm{t}$ of phosphate ore at a grade of 50 to $75 \mathrm{wt} \% \mathrm{P}_{2} \mathrm{O}_{5}$ and 5 to $20 \mathrm{wt} \% \mathrm{Fe}$. Pure collophane nodules represent $20000 \mathrm{t}$ at $78 \mathrm{wt} \% \mathrm{P}_{2} \mathrm{O}_{5}$ (Obellianne 1958).

On Walpole island $(3.5 \times 0.6 \mathrm{~km})$ a phosphate deposit of the same type is known with collophanebearing ore filling karstic voids (Habault 1987; Maurizot \& Lafoy 2003). First extractions started as soon as 1888 and continued intermittently until 1914. Operations were hampered by the remoteness and isolation of the island, the lack of fresh water, and the difficulty for a ship to dock. Hand-extracted production is estimated at $160000 \mathrm{t}$ of exported ore at a grade of $55-65 \mathrm{wt} \% \mathrm{P}_{2} \mathrm{O}_{5}$. A substantial remaining resource is estimated at 400 to 500000 t (Delvinquier \& Jegat 2001).

A small production of phosphate has also been reported from the islands of Huon and Surprise Reef at the northernmost continuation of the Grande Terre (Faivre et al. 1955; Paris 1981). In the Chesterfield Islands area small occurrences are reported on lle Longue (Koch 1957d), however, subsequent general prospecting by drilling failed to find any resource (Rossfelder 1986).

In all the Loyalty Islands deposits, economic or not, phosphate is associated with shallow marine (oolitic) sediments and freshwater deposits (speleothems) developed in reefal carbonate platform environments. Sea level variations, either eustatic or tectonic, are responsible for the development of a karstic morphology and phosphate concentrate in voids. Phosphatogenesis in the many so-called "high islands" of the Pacific has been a matter of debate. The guano model (i.e. accumulation of seabird excrements) has been long abandoned (although fish bone occurrence is an argument for this model) and a marine origin is favoured. For some authors, phosphorus could be volcanogenic, brought to the atolls by abundant stranded pumices or ash falls, since their geochemical signature is found in the bauxitic and phosphate deposits (Bourrouilh - Le Jan 1989, 1992, 1996; Tercinier 1971, 1972). Alternatively, phosphorus from the seawater is essentially bioaccumulated (Montagionni 1985). In the endo-upwelling model the geothermal heat flow provided by underlying volcanic substrate, drives phosphorus enriched deep oceanic water, penetrating through porous reef carbonates into the closed lagoon (Fikri 1991; Rougerie \& Wauthy 1989), followed by biogenically controlled massive precipitation of phosphate (Jehl 1995; Rougerie et al. 1997). This hypothesis is supported by trace and REE patterns in phosphate indicating both oceanic and basaltic sources (Bernat et al. 1991).

\section{Aggregate minerals}

Aggregate material supply (sand, gravel, crushed stone, and rip rap) have always been an issue in New Caledonia. This situation result from a non-steady economic growth with sudden phases of development (e.g. world class mining project since 2000's), and strong environmental constraints. Apart from the major mining projects, the main demand and supply are centred on Nouméa, and scattered along the south-western coast (Fig. 11). In 2014, c. 1.4 Mt of materials, all types, have been extracted (//dimenc.gouv.nc/mines-et-carrieres/les-carrieres) in the country, in no more than 10 
industrial quarries. Estimate demand for aggregate in 2025 is assessed to 2 to $3 \mathrm{Mt}$ (Lebret \& Maurizot 2007).

Geological constraints are pregnant. The variety of available material is restricted. In the Loyalty Islands (cf chapter 6, this memoir), $100 \mathrm{~km}$ away from Grande-Terre, limestone is this only available material. On Grande Terre, the presence of Natural Occurring Asbestos (NOA) in many geological units is a major issue. Although there is no mineable concentration of asbestos in the country, NOA is a health concern which is taken into account by authorities. At last, the ubiquitous weathering, specific to the tropical areas, lowers the mechanical properties of all rocks, and bring further complexity in exploration as well as exploitation phases. Regions like the northern and eastern part of Grande Terre are devoid of any suitable aggregate resource because their geological environment is made of schists and ophiolitic melange potentially asbestos-bearing.

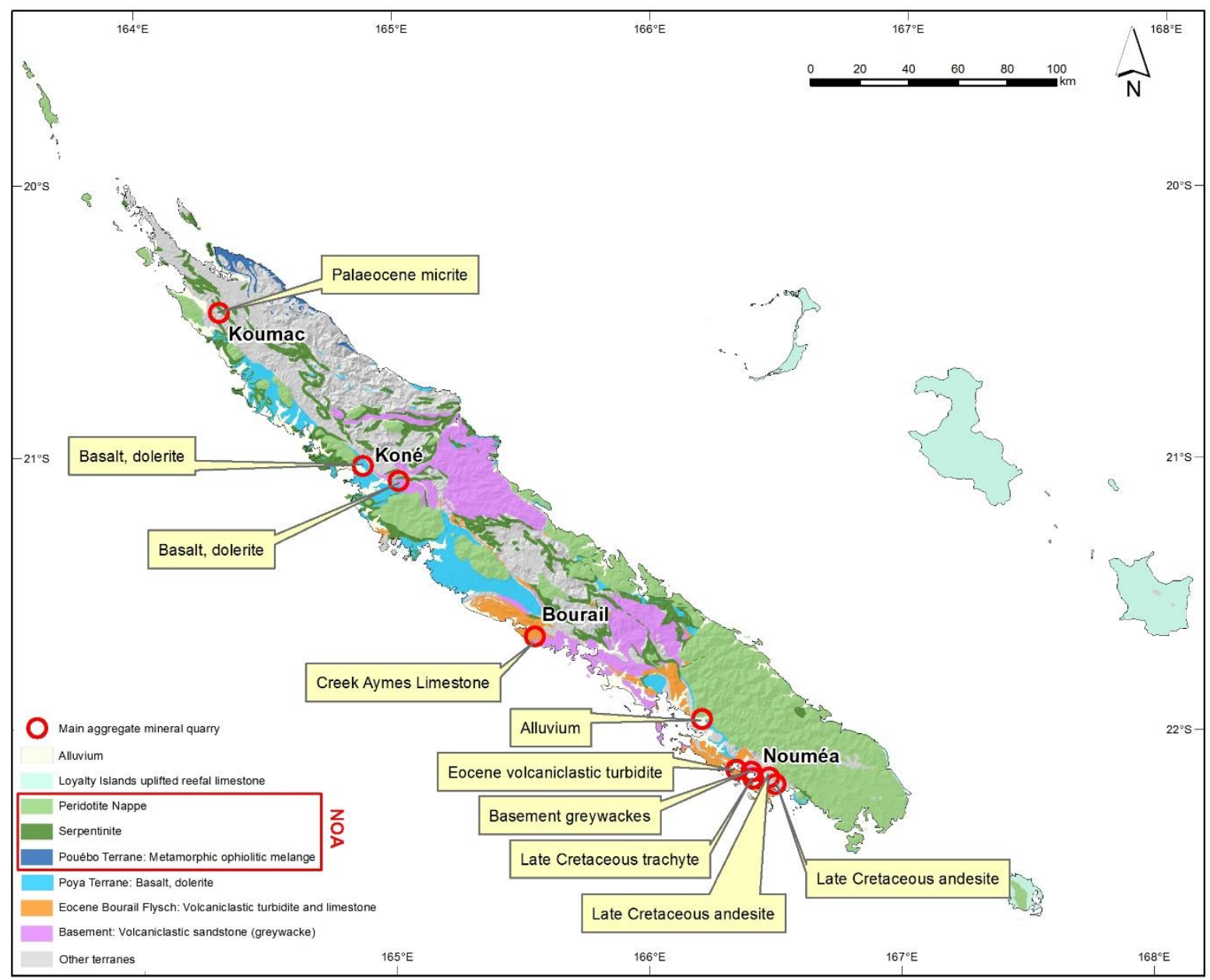

Fig. 11 Simplified geological map of New Caledonia showing aggregate potential and NOA bearing units (red frame), and main quarries producing aggregates (2016) with punctual indications on lithology or geological formation operated.

Exploitation of sand and gravel in main rivers is declining or is restricted to specific areas, and will be likely prohibited in the near future, due to the ubiquitous presence of ultramafic-derived detrital rocks potentially NOA-carrying, and in order to protect water resource as well (Garcin 2009, 2010; Garcin \& Lesimple 2013b, a). 
Materials from the lagoon, although they were prospected or even locally exploited during the 1990s (Maurizot \& Bouysse 1989) are nowadays no more conceivable as a resource. Part of the lagoon is designated since 2008 as a UNESCO world heritage protected area.

Exploitation of ultramafic rocks (serpentinite and peridotite) as aggregate for concrete or sealing roads, is forbidden, and construction works in ultramafic environment is strictly controlled (2010-4553/GNC act including maps of NOA bearing geological units, www.juridoc.gouv.nc). More than one third of the area of Grande Terre consists of ultramafic rocks and it is not possible to go a few kilometres across the main island without cross cutting an ultramafic formation. NOA occurrences and related health issues (lung cancer, malignant mesothelioma) in New Caledonia are known since the 70s (Goldberg 1994; Goldberg 1991; Goldberg 1995; Goldberg et al. 1995; Lessard 1978; Luce 2000; Luce et al. 2004). Serpentinite, which is a rather good material, due to its mechanical properties, easy to quarry, and generally not weathered, has been widely used by the past, for sealing tracks inside the country. Strong evidences where provided that this material for road surfacing was a major environmental risk factor for mesothelioma in New Caledonia (Baumann 2011; Baumann 2012, 2015; Baumann et al. 2007).

Given these constraints, the main remaining targets for crushed stones are volcaniclastic rocks and lavas. Also greywackes of the basement are widely exposed their remote localisation, mainly in the Central Chain, did not favour their exploitation. Around Nouméa the main quarries have been opened in the Late Cretaceous lavas, either basalt, andesite, or trachyte (cf. chapter 4, this memoir), in the greywackes of the Central Terrane (cf. chapter 3, this memoir), and in the Eocene volcaniclastic turbidites (cf. chapter 4, this memoir). The relative thinness of Late Cretaceous lava flows (some tens metres) makes the monitoring of operation rather complex. Contamination by interlayered sedimentary rocks is an issue. Basalts of the Poya Terrane is quarried near to Koné. The Creek Aymes Limestone (cf. chapter 4, this memoir) at the base of the Eocene Flysch is exploited near Bourail.

\section{Clays}

Clay occurrences in New Caledonia are mostly of weathering origin. Consequently most of accumulations are discontinuous, with a high variability, and contain impurities or unweathered fragments of bedrock. In 2016, there is still no exploitation of clays in the country. An assessment of the resource has been anyway attempted in the 90s (Le Berre 1990b, 1991). The weathering profiles (cf chapter 7, this memoir) which have been prospected are lying on the Late Cretaceous argilites and mudstones, the cumulate gabbros of the Peridotite Nappe at Mouirange, the Boghen Terrane, and the Poya Terrane. Some potential sources and use may be mentioned.

On argillite and schists, the lateritic part of the weathering profile does not exceed $3 \mathrm{~m}$ in thickness, as a ferruginous red clay. In the early times of colonisation, these horizons have been exploited in the Mont Dore area, and a brick factory was build up for local buildings. Although discontinuous and thin, the weathering profile on schists of the Boghen Terrane pertains to major palaeosurfaces with an extent of several tenths of $\mathrm{km}^{2}$ that may compensate this discontinuity. Clays are composed of a mixture of kaolinite, gibbsite, metahaloysite, and smectite, with goethite and haematite. $\mathrm{Al}_{2} \mathrm{O}_{3}$ content is commonly wt $20 \%$, and may reach locally c. $30 \%$. This material could be suitable in local use for handmade brick, however this is not a traditional material for constructions.

Kaolinite and gibbsite rich deposits are associated with cumulate gabbros of the Peridotite Nappe. The best exposed and easily accessible occurrences are located in the area of Mouirange. A rather pure deposits of kaolinite, $10 \mathrm{~m}$ thick, is located in the Rivière des Pirogues watershed. The lower part 
corresponds to 'in situ' weathering profile on gabbros. The upper part corresponds to reworked sediments at the base of the Fluvio-Lacustrine Formation. This material is more appropriate for ceramic.

Clays, as vertisol bearing gypsum, may reach $3 \mathrm{~m}$ in thickness on some areas of the Poya Terrane, on the south-western coast. They are mainly composed of swelling clays with a content of c. wt $15 \%$ $\mathrm{Al}_{2} \mathrm{O}_{3}$, and is not suitable for construction material.

\section{Dimension stone}

The principal rock types that can be used as dimension stone have been investigated in the 1980s and 1990s (Colleau 1984; Le Berre 1991; Paris 1982). Only one exploitation was attempted near Koumac, where two quarries have been operated for some years, with government financial support, in the Paleocene micrite and the Early Eocene pink calciturbidite. This last rock type yielded a pink "marble" (Maurizot 2011) that passed normative tests, had technical and industrial requirements, and was suitable as a commercial product (Maurizot \& Le Berre 1991, 1992). It was used locally in a few buildings, and however never exported.

\section{Limestone for cement or neutralizer}

The main limestone formations of New Caledonia are:

on Grande Terre, the Palaeocene micrite (cf. chapter 4, this memoir), the bioclastic limestone at the base of the Eocene Flysch (Middle Eocene Creek Aymes Limestone, Late Eocene Uitoé Limestone, cf. chapter 4, this memoir), the Miocene Népoui limestone (precisely the Wharf Member of the Upper Népoui Limestone, cf. chapter 7, this memoir).

In the Loyalty Islands (cf. chapter 6 , this memoir) which are entirely made up of reefal and bioclastic limestone, huge resource of reefal limestone is available.

Limestone formations have been prospected for cement use in the 90s (Le Berre 1990a), in order to lower imports of clinker in the country, and as neutralizer in order to buffer the acid effluents of the hydrometallurgic nickel industry, since the 2000s.

Palaeocene limestone is not a suitable material for cement due to a high SiO2 content, presence of cherts, and hardness of the rock. The Miocene Népoui limestone has been investigated by core drills (Le Berre \& Maurizot 1992; Noël 1992), with favourable preliminary results that were not followed up. The Eocene limestones have not been investigated.

For neutralizer purpose, the requested material is a pure limestone ( $>95 \% \mathrm{CaCO}_{3}$ ) with very low $\mathrm{Mg}$ content. The Népoui Limestone has been investigated by core drills (Tessarolo 1997). The limestone beds are alternating with laterite and Mg-rich ultramafic-derived weathering products and that material revealed to be unsuitable.

Whatever be the purpose, cement or neutralizer, the Loyalty Islands present huge resource of limestone, however the remoteness from the centres of consumption, all located on Grande Terre, and the environmental as well as societal constraints are not to be underestimated. Limestone outcrops with karstic caves that may contain human remains are protected and sacred places in New Caledonia. 


\section{Gemstones}

Jade is a relatively common rock in ophiolitic terranes. The semi-precious stone is formed by a monomineralic assemblage of thin tufts of tangled and twisted fibers forming a dense thatch resulting from crushing and recristallizing under ultramylonitisation conditions. Owing to this structure, it is a very tough rock with a hardness of 6 to 7 on the Moh scale. "Nephrite jade » is constituted by an assemblage of amphibole of the tremolite - actinolite series. " Jadeite jade » is constituted by the sodic pyroxene jadeite. The term semi-nephrite (Turner 1935) applies to incompletely crushed rocks with relict porphyroclasts.

Jade

Jade (sensu lato) is a relatively common rock in ophiolitic terranes. The semi-precious stone is not the pyroxene jadeite mineral but is a monomineralic assemblage of thin tufts of tangled and twisted fibres that form a dense thatch. The exact conditions of formation are speculative but may have taken place under ultramylonitisation conditions. Because of the twisted fibre structure, it is a very tough rock with a hardness of 6 to 7 on the Moh scale. Chemically and mineralogically, nephrite jade is an amphibole of the tremolite - actinolite series. Jadeite jade is constituted by the sodic pyroxene jadeite. The term semi-nephrite (Turner 1935) applies to incompletely recrystallised rocks with relict mineral porphyroclasts.

Jade in New Caledonia is more important from an archaeological and heritage point of view rather than from a business and economic perspective. Like other Pacific Island populations, the first inhabitants of New Caledonia have known and used the jade as tools or as ritual objects. In the objects collected by archaeologists (ceremonial axes, pearl necklaces, adzes) many are made from either serpentinite or jade. Ouen Island is the most oft-cited source of jade (Lacroix 1942) but it is likely that other sites were discovered by the Kanak, most of the locations now being unknown. The geological units of New Caledonia that may provide jade are: i) The Boghen Terrane, a Mesozoic HP-LT metamorphic subduction complex, where nephrite occurrences are found at the serpentinite-schist contact (cf. chapter 3, this memoir). ii) The Eocene HP-LT metamorphic Pouébo Terrane of northern New Caledonia. In principal, crystalline jadeite jade (sensu stricto) could exist here but it has not yet been discovered (cf. chapter 5, this memoir). iii) The Peridotite Nappe where various gabbros, either dykes or cumulates are often highly sheared and mylonitised (cf. chapter 5, this memoir).

Several nephrite jade sites have been studied to varying degrees, and have been permitted for occasional contemporary extraction.

Ouen Island is certainly the best known and most studied site. The rock is a semi-nephrite with pyroxene porphyroclasts and has no or very low commercial value. It is possible that in the past more substantial blocks of better quality nephrite were collected by the Kanak, but no trace now remains.

The Rivière Bleue occurrence consists of alluvial pebbles and cobbles in this large river. The primary source upstream is not known.

The Rivière des Pirogues jade occurrence was worked for a few years in the 1990s. The host rock typically consist of highly sheared basic dykes cutting through the Peridotite Nappe, belonging to the $53 \mathrm{Ma}$ intrusives (Cluzel et al. 2006). The quality of the jade varies from semi-nephrite to pure nephrite. The in situ dykes are naturally dismembered by the stream. The pebbles and cobbles, cleaned by the current, driven downstream over several kilometres, were simply collected in the river bed. 
In summary, for the currently known occurrences in New Caledonia, nephrite jade does not occur in massive and consistently good quality in situ lenses. There is a small, local local arts and crafts market in "Caledonian jade" but nothing like the status of true jade on the international gemstone market.

\section{Chrysoprase}

Silica leached during the weathering of ultrabasic rocks may precipitate as more-or-less well crystallized products corresponding to an intimate mixture of quartz, chalcedony, and opal. They are variously coloured by inclusions such as iron oxy-hydroxides, serpentines and/or $\mathrm{Ni}$ bearing phases. Green varieties of silica veins, coloured by nickel (Hatipoglu et al. 2011), are called chrysoprase (green chalcedony) and prasopale (green opale), and are of gemmologic interest.

"Chrysoprase" is reported from several places in the Peridotite Nappe, as veinlets at and below the base of weathering profiles. Specific tenements have been granted in the past in the Ouaco area but none is still presently valid. The major phase is an Opal-CT with minor opal-A, and inclusions of sepiolite and paragonite. The Ni content is of 0.3 to $6.4 \mathrm{wt} \%$. The deepest green colour corresponds to the higher Ni content (consultancy reports, SGNC). The strict term prase-opal would better apply to this material.

Chrysoprase (sensu lato) is used occasionally for local arts and crafts where it is often confused with jade. New Caledonia material is not known on the international gemstone market and the very limited production is not exported.

\section{Hydrocarbons}

\section{Coal}

Coal in New Caledonia is found in the Late Cretaceous "Formation à charbon" as seams and lenses 1 to 2 metres thick and 10 to 50 metres long (cf. chapter 4, this memoir). These were discovered and described in the early times of European colonization (Garnier 1867a; Heurteau 1876).

Coal potential was actively investigated in the 1950s (Espirat 1957, 1958; Koch 1957c; Noesmoen 1957a, b, 1959a, b; Pomeyrol 1952). The coal measures are generally the uppermost beds of fining upwards flodd plain successions (conglomerate, cross bedded sandstones, mudstone, coaly mudstone, coal) typical of fluvio-deltaic environments of that syn-rift period. Coal beds are strongly tectonised by disharmonic folding and thrusting, mechanically weak coal horizons preferentially localising detachments. Coal seams may locally reach several metres thickness by strutural hinge thickening but conversely may pinch out rapidly.

The main areas prospected by trenches, pits, galleries, and drills are located to the NW of Nouméa, and near Moindou and Voh. The only significant mining of these deposits took place near Moindou on the west coast between 1924 and 1930, where c. 77000 tons of coal were produced and used in the first nickel smelters in Nouméa. However, the tectonic complexity has prevented any profitable mining exploitation of this resource, and by 1930, it became clear that, due to the poor quality of the coal, and the high cost of its extraction, it could not compete with other imported, mainly Australian, coke.

Nowadays, coal of the "Formation à charbon" is considered as a potential hydrocarbon source rock for an offshore New Caledonian oil and gas resources. This is by analogy with the Late Cretaceous Rakopi Formation (Killops et al. 1994) of NW New Zealand which is the source rock for the productive offshore 
Taranaki Basin (Cook 1987; Herzer et al. 1999, and other references in Hydrocarbon section, this memoir).

\section{Oil and gas}

Oil and gas shows have been known since the beginning of the 20th century in the western part of the Grande Terre. The Late Cretaceous to Eocene cover (cf. chapter 4, this memoir) has been considered as a potential petroleum system and, as such, the Nouméa and Bourail area were explored during the 1950s (Pomeyrol 1951; Tissot \& Noesmoen 1958). In the 1970s several oil companies obtained seismic exploration permits offshore New Caledonia. The associated surveys revealed fairly thick sedimentary series in the basins surrounding New Caledonia (Ravenne 1982). In the beginning of the 1990s the ZoNéCo research program was launched to evaluate the natural resources of the EEZ of New Caledonia. A generation of modern data were then acquired, providing new insights onto the geometry and nature of known basins and allowing a renewal of interest for offshore hydrocarbons in the 1990s (France 2000). Since then, even more data have been acquired but, in a global context, the area remains very poorly explored and is considered a frontier area (Sutherland et al. 2012).

\section{Onshore}

Direct Hydrocarbon Indicators (DHIs) are crucial elements in assessing petroleum potential. In Nouméa, a drillhole was bored, in 1909, near Ouen Toro, close to known oil seeps in Paleocene Limestone (Haas 1932; Maurizot \& Gasc 1986). The well reached a depth of $423 \mathrm{~m}$, crosscutting the Eocene Flysch and various olistoliths. Small quantities of gas were expelled and ignited, however, given that it is now understood that the hole was drilled into accretionary prism strata, an olistostrome, and probably a large olistolith, it was very unlikely to find any appreciable hydrocarbon reservoir.

Oil seeps were discovered in the 1910s, in northern New Caledonia, to the south of Koumac village, at a place today known as "La Mine d'Huile" (Oil Mine). These seeps are found in a rather unusual location within the serpentinite sole of a small peridotite klippe which overlies the Poya Terrane basalts. The area was first explored by a few shallow pits and a gallery. From 1914 to 1918 and in 1954, drilling down to 185 m depth, was carried out along a NE-SW section (Pomeyrol 1951; Vially \& Lafoy 2008). The drilling revealed two oil shows in the serpentinite. Unfortunately, oil dilution in the water and contamination by organic matter, precluded recovery of enough material for confident analyses. The only substantial conclusion was the natural character of the oil. This unusual natural seepage in an allochthonous ultramafic terrane indicates that oil generation did take place, and that the oil probably had a long and complex migration pathway from an unknown sedimentary source rock. According to Vially \& Mascle (1994) the source rock could be coal measures located in a Cretaceous basin overthrust by the allochthons.

The Bourail Anticline (Pomeyrol 1951; Tissot \& Noesmoen 1958), involves a succession of Eocene turbidites, c. $4 \mathrm{~km}$ thick, overlying Late Cretaceous to Palaeocene series. The anticlinal axis is $25 \mathrm{~km}$ long and dips northwestward to form a pericline in the Montagnes Blanches area (Maurizot 2014). This simple structure, potentially a classic hydrocarbon structural trap, was identified as a target for petroleum exploration in the 1950s. Several exploration boreholes were therefore drilled near the anticlinal axis. Boreholes Gouaro-1 (608 m) and Gouaro-2 (441 m) were drilled in 1954 and 1955, respectively (Pomeyrol 1955); both remained in the Eocene Flysch (Paris 1981). Gouaro-1 crosscut some gas showings. A more recent campaign (France 2000) also targeted the Bourail Anticline. It consisted of a seismic reflection survey (Blake 1996), and a 1930 m-deep exploration borehole (Cadart- 
1), almost entirely core-drilled in 1999 (Maurizot 2005). It recovered a significant interval of the Eocene Flysch and reached the uppermost part of the Late Cretaceous formations. Significant gas shows were encountered and ignited, while oil inclusions were observed in some calcite filled fractures within the Eocene Flysch. This borehole, the deepest ever drilled in New Caledonia, therefore provides a unique data set for the understanding of the island's geological framework and evaluation of its petroleum potential.

\section{Hydrocarbon system model}

These tiny onshore New Caledonia showings demonstrate that a hydrocarbon system existed (Vially \& Lafoy 2008) and likely has a continuation offshore.

The inferred system is similar to that of New Zealand which is today productive and actively prospected. In the onshore New Zealand region, Taranaki Basin is New Zealand's only productive hydrocarbon gas-rich basin (King et al. 1999; King \& Thrasher 1996; Uruski 2008). Late Cretaceous carbonaceous sandstones and mudstones, typically associated with coal measures, of the Rakopi Formation, are the source of most of the oil. Rakopi Formation extends offshore mainly in the Taranaki Basin (Killops et al. 1994), and a correlative has also been dredged on the western flank of the West Norfolk Ridge (Herzer et al. 1999). In New Caledonia, Late Cretaceous coal measures are also likely source rocks but the reservoir and seal are different from Taranaki Basin. The fractured sandy Eocene turbidites are suspected for the reservoirs, and shaly Eocene turbidites for the seal (cf. Bourail Flysch, and chapter 4 , this memoir).

\section{Offshore potential}

The offshore area between Australia, New Caledonia, and New Zealand has been called the Tasman Frontier (Sutherland et al. 2012). It is a vast under-explored area in the southwest Pacific predominantly underlain by submerged continental crust, and corresponds to the northern part of Zealandia as defined by Luyendyk (Luyendyk 1995; Mortimer 2008). It hosts several large unexplored sedimentary basins that share a common origin with producing basins such as the Gippsland and Taranaki basins respectively in Australia and New Zealand. Although no exploration drilling has taken place in northern Zealandia other than in the Taranaki Basin and vicinity, this vast area offers a wide range of potential petroleum prospects. The only existing drilling data in the region are from the Deep Sea Drilling Project (DSDP) carried out during 1971-1973 and in 1982 (Burns \& Andrews 1973; Burns et al. 1973). During the 1990s and early 2000s, data acquisitions, including reflection seismic, gravity, magnetic, multibeam bathymetric information and rock dredge sampling, have been driven by government initiatives and UNCLOS (United Nation Convention on the law of the sea). This provides a useful framework for petroleum exploration in the different EEZ. Together, these data represent more than $100000 \mathrm{~km}$ of profile and are gathered in the publicly available Tasman Frontier Database (Sutherland et al. 2012). 

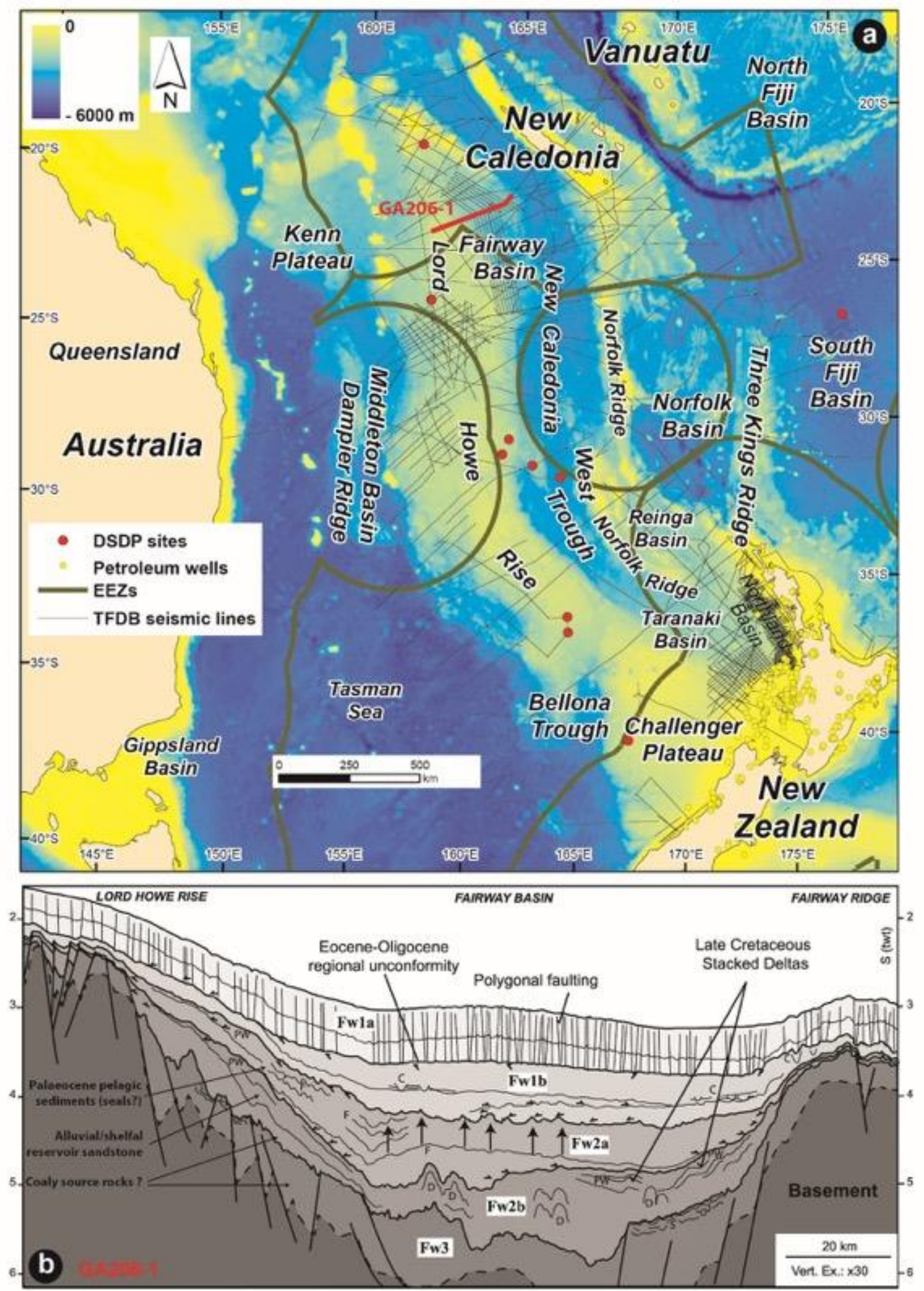

Fig. 12 a) Bathymetric map showing positions of all publicly available seismic lines of the Tasman Frontier Database (TFDB, Sutherland et al., 2012), Deep Sea Drilling Project (DSDP) wells, petroleum exploration wells and the limits of Australia, New Zealand and France/New Caledonia Exclusive Economic Zones (EEZs). Bathymetric data from Global Predicted Bathymetry V18.1 (Smith \& Sandwell, 1997). Red line indicates location of seismic profile GA206-01. b) Seismic 
profile GA206-01 across the Fairway Basin (modified after Rouillard et al., 2014 and Rouillard et al., 2015). Seismic stratigraphic units Fw1: Post-rift, Fw2: Syn-rift, Fw3: Pre-Rift. Key to annotations: C: Turbidite channel-fills; D: Diapirs; PW: Prograding wedges; Vertical arrows: Fluid escapes.

Several basin studies including maturity and prospectivity assessments of the Fairway Basin west of New Caledonia have been conducted (Kroeger \& Funnel 2011; Vially \& Bernard 1999; Vially \& Lafoy 2005, 2008; Vially \& Mascle 1994). Kroeger \& Funnel (2011) reviewed model predictions for the maturity of potential source rocks and volumes of oil and gas expelled, and presented likely migration pathways for charge of potential reservoir structures.

Althought several sedimentary basins have a hydrocarbon potential in the wider Tasman Frontier area, New Caledonia petroleum prospectivity assessments e.g. (Exon et al. 2007; Kroeger \& Funnel 2011; Rouillard et al. 2014) have typically focused on the the Fairway Basin, mainly due to its relatively good data coverage when compared to nearby basins. Water depths of the Fairways Basin, range from less than $1000 \mathrm{~m}$ to $2400 \mathrm{~m}$. Previous studies conducted on this basin have revealed a sedimentary cover greater than 3,000 $\mathrm{m}$ in thickness (Ravenne et al. 1977). The basin contains an inferred near-complete Cretaceous-Cenozoic sedimentary cover which comprises deeply buried Cretaceous stacked deltas (Rouillard et al. 2015). The basin probably formed in the late Early to Late Cretaceous, during eastern Gondwana breakup, and has received detrital and pelagic sediments since that time (Exon et al. 2007; Lafoy et al. 1994; Rouillard et al. 2015). Recent wide-angle refraction seismic studies revealed a $15 \mathrm{~km}$ thick continental crust beneath the basin (Klingelhoefer et al. 2007). More than 100 diapirs have been mapped within the sedimentary column and a bottom simulating reflector (BSR) has been identified across an area of 70,000 km² (Auzende et al. 2000a; Auzende et al. 2000b; Auzende et al. 2000c). This BSR was initially interpreted as being the world's largest gas hydrate field, but subsequent reinterpretation from high-resolution refraction seimsic data and heat flow measurements suggested that the reflector was related to an opal-A to opal-CT diagenetic front (Nouzé et al. 2009).

When considering the structural continuity with the Taranaki Basin of New Zealand (Collot 2009; Collot et al. 2009), the above observations and interpretations form strong evidence for the petroleum potential of the Fairway Basin.

\section{Thermo-mineral springs}

Two types of warm springs are known in New Caledonia. On the eastern coast, several small springs are scattered between Thio and Canala. In the south of Grande Terre hyperalkaline springs are found in the ultramafic Massif du Sud (Fig. 13). Both are of low enthalpy type and present low rates of flow and thus a weak potential in term of geothermal energy. 


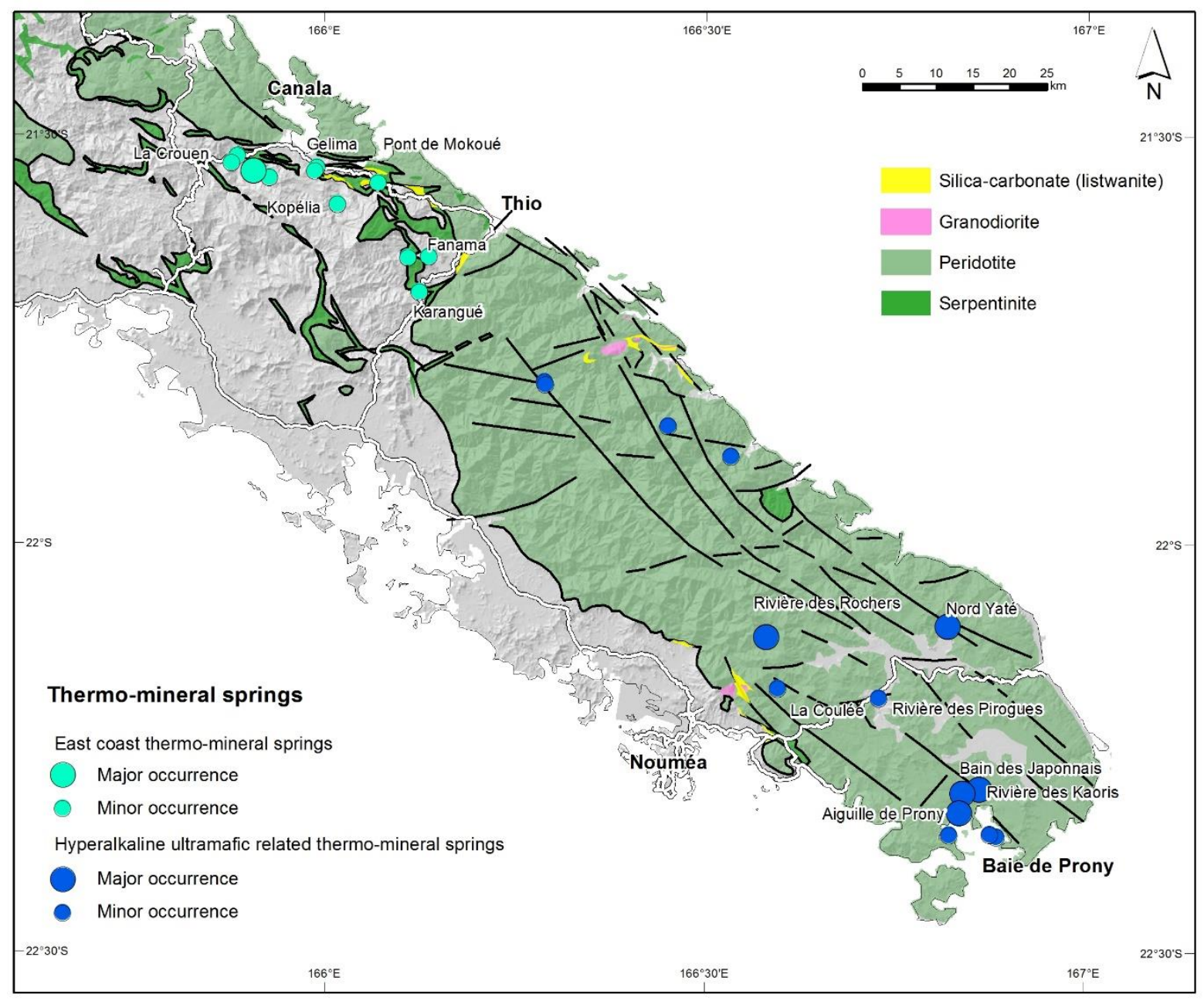

Fig. 13 Thermo-mineral springs of Grande Terre, New Caledonia.

\section{East Coast springs}

The springs are distributed over a $30 \mathrm{~km}$ zone roughly parallel to the east coast, below the basal thrust sole of the Peridotite Nappe. The springs emerge from either the autochthonous basement or the Poya Terrane, and always in the vicinity of serpentinite slices or listwanite. Gas bubbling can be observed at many of the springs, and as previously noted (Cox et al. 1982), most of these springs are in topographic lows, close to a river, or in river bed. The main springs are located at La Crouen where thermal baths have been located in the past (Koch 1958d). In this area fourteen small low temperature seepages are located along the river and discharge in it.

Some characteristics of the waters are given in table 3 . When the flow is low, the temperature of the temperature of the spring waters is close to ambient. All of them have a sulphurous odour. All have the same composition of $\mathrm{Na}-\mathrm{HCO}_{3}-\mathrm{Cl}-\mathrm{SO}_{4}$ type and $\mathrm{pH}$ values are either neutral or slightly alkaline. Stable isotopes of oxygen and hydrogen indicate a meteoric origin of these waters (Cox et al. 1982). Many of the springs deposit white precipitates (likely chalcedony according to Cox 1982) associated with filamentous algae (Avias 1949; Cox et al. 1982).

A speculative relation has been attempted between the present-day thermal springs and the sulphur occurrences of the post-obduction Sb-Au-As-Hg deposits or listwanite (cf. Post-obduction magmatism, 
this chapter), although these mineralisation is associated with the much older Late Oligocene granodiorites (Cox et al. 1982).

\begin{tabular}{lcccc}
\hline Name & $\mathrm{T}^{\circ} \mathrm{C}$ & Flow $\mathrm{l} / \mathrm{s}$ & $\mathrm{pH}$ & $\begin{array}{c}\text { Conductivity } \\
(\mu \mathrm{S} / \mathrm{cm})\end{array}$ \\
\hline La Crouen & $40-43$ & 3 & 8 & \\
La Crouen (small seepages) & $22-27$ & $<0.1$ & 8 & 250 \\
Gelima & 29 & $<0.1$ & 9 & \\
Karangué & Ambient & $<0.1$ & & 550 \\
Fanama & 32 & 0.5 & 8 & \\
Pont de Mokoué & 28 & $<0.1$ & 8 & \\
Kopélia & Ambient & $<0.1$ & & \\
\hline
\end{tabular}

Table 3. Some characteristics of the East Coast thermo-mineral springs (Cox et al. 1982; Paris 1981, and this work).

\section{Hyperalkaline ultramafic related springs}

Several hyperalkaline springs are known in the Peridotite Nappe of the Massif du Sud. These are both onshore and underwater. In the southern lagoon, the most famous is in the Baie de Prony, where it is responsible for the formation of the well-known Aiguille de Prony. Several other springs have been found on land in river beds (Fig. 13). The Baie de Prony hydrothermal field was extensively studied during the HYDROPRONY cruise (Oct-Nov 2011). In the Baie de Prony, one of the springs is on land above sea level (Rivière des Kaoris), one is in the tidal zone and uncovered at low tide (Bain des Japonais), and several are underwater in the lagoon. In the middle of the Baie de Prony, the Aiguille de Prony, known since the 19th century (Garnier 1871), is a pinnacle towering $35 \mathrm{~m}$ above the seafloor, with its summit $2 \mathrm{~m}$ below sea level (Launay \& Fontes 1985). A recent bathymetric survey of the seafloor of the bay has revealed the existence of other submarine hydrothermal formations, at water depths between 30 and $50 \mathrm{~m}$ (Pelletier et al. 2006). The springs are characterised by precipitation of carbonate forming travertine terraces, low temperature, low salinity, gas bubbling, and high pH. Contrary to what is commonly reported, these springs are not correlated with obvious serpentinised fault zones. No correlation between the spring locations and tectonic features like faults has been demonstrated so far. Instead they occur in the vicinity of rivers.

Waters collected at these springs are of the $\mathrm{Ca}-\mathrm{OH}$ type (Monnin et al. 2014) and are characterized by very high $\mathrm{pH}$ values (up to 11.2), a low salinity (even those located in the lagoon) which is indicative of their meteoric origin, and common bubbling of $\mathrm{H}_{2}$ and $\mathrm{CH}_{4}$-enriched gases (Monnin et al. 2014). These hyperalkaline hydrothermal fluids result from present day serpentinization reactions (Barnes \& O'Neil 1969), involving aqueous alteration of Fe and Mg silicates of peridotite (olivines and pyroxenes). It involves dissolution of primary minerals, and precipitation of secondary serpentine, magnetite, and brucite. The oxidation of metals (mainly iron and to a lesser extent, nickel) contained in the olivines and pyroxenes and the reduction of water, produce a $\mathrm{H}_{2}$ enriched gas phase and very alkaline fluids. Further reactions of hydrogen with either organic matter or oxidized carbon compounds may lead to the formation of abiotic methane (Chavagnac et al. 2013; Chavagnac et al. 2014). In the Baie de Prony hydrothermal field, mixing of the hydrothermal end-member with the lagoon water is responsible for the precipitation of brucite and Ca-carbonates that can accumulate either as platforms uncovered at low tide (Bain des Japonais) or as underwater masses (Aiguille de Prony). 
Some of the characteristics of hyperalkaline springs in the Massif du Sud are given in table 4.

Onland, mixing of hyperalkaline fluids with surface freshwater leads to the precipitation of dominant calcium carbonate whilst offshore, brucite is dominant. Gas bubbles at Bain des Japonnais and Rivière des Kaoris contains between 12 and 30 volume \% hydrogen in dry gas, 6 to $14 \%$ of methane, and 56 to $72 \%$ of nitrogen, with trace amounts of carbon dioxide, and other hydrocarbons (Monnin et al. 2014). The Aiguille de Prony hosts chemolithotrophic microbial communities adapted to the hyperalkaline environment (Ben Aissa et al. 2015 ; Quéméneur et al. 2014).

The Baie de Prony hydrothermal field is an example of a serpentinizing environment (Schrenk et al. 2013) and shares common characteristics with the Lost City Hydrothermal Field near the mid-Atlantic Ridge (Kelley et al. 2001). Because of its accessibility, Baie de Prony could become a privileged laboratory to address fundamental questions related to the study of low temperature serpentinization, such as the alkaline hypothesis for the origin of life, the subsurface $\mathrm{CO}_{2}$ storage by peridotite carbonatisation, the long term alteration of natural cement analogues and its consequences for the storage of radioactive waste, the extension of the biosphere in the ocean floor and in the mantle, the geological history of seawater and methane production in ultramafic formations exposed at the surface of Mars.

\begin{tabular}{ccccc}
\hline Name & $\mathbf{T}^{\circ} \mathbf{C}$ & Flow $/ \mathrm{s}$ & $\mathrm{PH}$ & $\begin{array}{c}\text { Conductivity } \\
(\boldsymbol{\mu} / \mathbf{c m})\end{array}$ \\
\hline Nord Yaté & 24 & 11.7 & \\
Rivière des Rochers & 26 & 11 & 281 \\
La Coulée & 30 & 0.17 & 10.8 & \\
Bain des Japonais & $37-40$ & 0.2 & 11 & \\
Rivière des Kaoris & 32 & & 10.8 & \\
\hline
\end{tabular}

Table 4 Some charasteristics of the hyperalcaline thermo-mineral springs from Massif du Sud (Cox et al. 1982; Launay \& Fontes 1985; Monnin et al. 2014, and this work).

\section{Conclusions}

Mineral resources of New Caledonia are the end result of a c. 300 million years of geological and tectonic development in dominantly oceanic to arc settings. There is a clear spatial and genetic relationship between type of mineralisation and specific rock units and paleo-environments.

The only known deposits in the basement are in the crustal part of the Late Carboniferous Koh Ophiolite, as minor VMS-type copper and gold showings. Surprisingly, there are no major exposed VMS type deposits in the partly co-eval Téremba Terrane, even in the seemingly favourable Late Permian arc-related proximal volcanic setting. Within the cover, the Late Cretaceous period of rifting, is particularly fertile. It provided several VMS poly-metallic concentrations like the Diahot base metals, gold and silver SEDEX type deposits, and copper-gold Cyprus type deposits in the Poya Terrane.

Post-obduction granodioritic magmatism gave rise to original mineralisations including mainly $\mathrm{Au}$ and $\mathrm{Sb}$ at or near the base of the Peridotite Nappe, a major contact at New Caledonia scale.

Most of these metallic occurrences ar of little economic interest at present, but the presence of gold in most types should always be taken into account. 
Most of non-metallic resources including gemstones have been or are used locally. Even though they are not exported, they can represent significant economic value in the country.

Of interest for the long term, is the oil and gas potential of the New Caledonia EEZ within the wider Tasman Frontier area of northern Zealandia. A viable petroleum system has been demonstrated. This huge playground, in a submerged and complex geological region, will require a substantial effort of future marine exploration, through international programmes, sustained by high level research.

\section{Acknowledgements}

This work is the result of a formal and informal long term collaboration of a group of geologists from New Caledonia, New Zealand and Australia. We thank the mining companies, especially Société Le Nickel, Vale NC, Société des Mines de la Tontouta and Nickel Mining Company for sharing information, and for constructive and thoughtful reviews. We acknowledge the Government of New Caledonia for providing access to unpublished literature on mines, including statistics on resource, reserve, ore grade, and productions. This chapter was improved by reviews from Dave Craw and Nick Mortimer. 


\section{Illustrations}

Fig. 1 a) Geological map of New Caledonia. b) EEZ of New Caledonia and position of some remote islands. c) Legend showing (in red) main metallic mineral resources (including ultramafic related, cf. chapter 10, this memoir), hydrocarbons, phosphate, and their associated terrane. VMS: Volcanogenic Massive Sulphide; Sedex: Sedimentary Exhalative; BM: Base Metals

Fig. 2 Locations of the main VMS and manganese deposits in the Koh Ophiolite and Poya Terrane. ... 8 Fig. 3 Diahot Basin geological map and mineral deposits: a) Extent of the Late Cretaceous Diahot

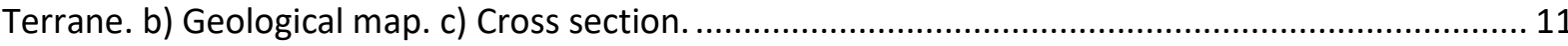
Fig. 4 Geological maps and cross sections of a) Pilou mine; b) Mérétrice mine.................................. 14

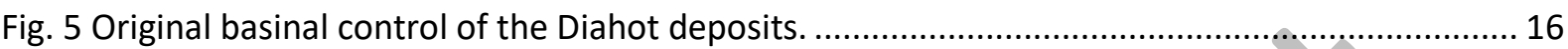

Fig. 6 Simplified geological map showing the principal features of the $\mathrm{As}, \mathrm{Au}, \mathrm{Sb}, \mathrm{Hg}, \mathrm{W}$ mineralizations associated with granodioritic post-obduction intrusions and silica-carbonate (listwanite). Small yellow labels: showings; Orange labels: deposits.

Fig. 7 Geological maps of Saint Louis and Koum (same scale) post-obduction granodiorites with associated mineralisations. a) Saint Louis geological maps showing the complex relationship of the granodiorite with both authochtonous substrate and allochthonous Poya Terrane and Peridotite Nappe. b) Koum geological map. c) Detailed map of Koum D1 gold prospect; dashed red rectangle encloses the area with $2 \mathrm{ppm}$ Au average content.

Fig. 8 a-b) Geological maps and c) cross sections of the Nakéty antimony deposit.

Fig. 9 Matthew and Hunter islands along with other volcanic structures forming an island arc, at the southeastern termination of the New Hebrides subduction zone. A N-S spreading ridge (thick red line with arrow) is visible in the NE, propagating to the SW into the arc. White line to the east and north: limits of the New Caledonia EEZ; EB: D'Entrecasteaux Basin; LR: Loyalty Ridge; NLB: North Loyalty Basin; NFB: North Fiji Basin.

Fig. 10 Map of non metallic, hydrocarbon, and gemstone mineral resources of onshore New Caledonia.

Fig. 11 Simplified geological map of New Caledonia showing aggregate potential and NOA bearing units (red frame), and main quarries producing aggregates (2016) with punctual indications on lithology or geological formation operated.

Fig. 12 a) Bathymetric map showing positions of all publicly available seismic lines of the Tasman Frontier Database (TFDB, Sutherland et al., 2012), Deep Sea Drilling Project (DSDP) wells, petroleum exploration wells and the limits of Australia, New Zealand and France/New Caledonia Exclusive Economic Zones (EEZs). Bathymetric data from Global Predicted Bathymetry V18.1 (Smith \& Sandwell, 1997). Red line indicates location of seismic profile GA206-01. b) Seismic profile GA206-01 across the Fairway Basin (modified after Rouillard et al., 2014 and Rouillard et al., 2015). Seismic stratigraphic units Fw1: Post-rift, Fw2: Syn-rift, Fw3: Pre-Rift. Key to annotations: C: Turbidite channel-fills; D: Diapirs; PW: Prograding wedges; Vertical arrows: Fluid escapes. 


\section{Tables}

Table 1 Summary of metallogenic and economic data of the main mines of the Diahot Basin. Locations on Fig. 3. Mined tonnages or reserves do not exceed $100000 \mathrm{t}$

Table 2 Summary of metallogenic and economic data of the main deposits of the As, Au, Sb postobduction mineralization. BM: base metals $(\mathrm{Cu}, \mathrm{Pb}, \mathrm{Zn})$.

Table 3. Some characteristics of the East Coast thermo-mineral springs (Cox et al. 1982; Paris 1981, and this work).

Table 4 Some charasteristics of the hyperalcaline thermo-mineral springs from Massif du Sud (Cox et al. 1982; Launay \& Fontes 1985; Monnin et al. 2014, and this work). 43 


\section{References}

Aitchison, J., Clarke, G., Meffre, S. \& Cluzel, D. 1995a. Eocene arc-continent collision in New Caledonia and implications for regional southwest Pacific tectonic evolution. Geology, 23, 161-164.

Aitchison, J.C., Clarke, G.L., Meffre, S. \& Cluzel, D. 1995b. Eocene arc-continent collision in New Caledonia and implication for regional SW Pacific tectonic evolution. Geology, 23, 161-164.

Arnould, A. 1954. Etude préliminaire sur les conditions de gisement du manganèse en NouvelleCalédonie. Internal Report, Service des Mines et de la Géologie, Nouvelle-Calédonie, Nouméa, 1-28.

Arnould, A. 1956. Les gîtes de manganèse volcano-sédimentaires de la Nouvelle-Calédonie. Un type de gisement de manganèse méconnu: le type volcano-sédimentaire. Symposium sur le Manganèse de Mexico, 1-11.

Auzende, J.-M., Beneton, G., Dickens, G., Exon, N., François, C., Hodway, D., Juffroy, F., Lafoy, Y., Leroy, A. \& Van de Beuque, S. 2000a. Mise en évidence de diapirs mésozoiques sur la bordure orientale de la ride de Lord Howe (Sud-Ouest Pacifique): campagne ZoNeCo 5. Comptes Rendus de I'Académie des Sciences-Series IIA-Earth and Planetary Science, 330, 209-215.

Auzende, J.M., Dickens, G.R., Van de Beuque, S., Exon, N.F., François, C., Lafoy, Y. \& Voutay, O. 2000b. Thinned crust in southwest Pacific may harbor gas hydrate. Eos, Transactions American Geophysical Union, 81, 182-185.

Auzende, J.M., Van de Beuque, S., Dickens, G., François, C., Lafoy, Y., Voutay, O. \& Exon, N.F. 2000c. Deep sea diapirs and bottom simulating reflector in Fairway Basin (SW Pacific). Marine Geophysical Researches, 21, 579-587, doi: 10.1023/A:1004848715044.

Avias, J. 1949. Hydrogeologie de sources thermales de la Négropo. Bulletin Spécial de l'Association Médicale de Nouvelle-Calédonie, 43-59.

Avias, J. 1952. Sur la formation actuelle de gypse dans certains marais côtiers de la NouvelleCalédonie. Comptes rendus XIXème session. Congrès géologique International, Alger. Section IV. Topographie sous-marine et sédimentation actuelle. Fascicule IV, 7-9.

Avias, J. 1953. Contribution a l'étude stratigraphique et paléontologique des formations antécrétacées de la Nouvelle-Calédonie centrale. Annales de l'école nationale supèrieure de géologie appliquée et de prospection de l'Université de Nancy., I, 1-276.

Avias, J. \& Routhier, P. 1962. Notice explicative de la carte géologique au 1 / 100000 PonérihouenPoya. Feuille $n^{\circ}$ 5. ORSTOM.

Aye, F. 1982. Inventaire des ressources minières du territoire de la Nouvelle-Calédonie; Rapport annuel 1981 Minéralisation en cuivre, or, plomb, zinc, argent du Diahot. Rapport BRGM 82 NOU 003, $1-48$.

Aye, F., Bonnemaison, M. \& Jacob, M. 1986. Etude gîtologique et géochimique des indices et anomalies en Sb, W, As, Au de la côte est de la Nouvelle-Calédonie. Programme Cordet, rapport final, 
85 NCL 079 GMX, BRGM, Secrétariat d'Etat auprès du Ministère de l'Intèrieur et de la Décentralisation.

Aye, F. \& Jacob, M. 1983. Etude gitologique des indices et anomalies en Sb, W, As, Au liées aux fractures granitisées de la cote est de la Nouvelle-Calédonie. BRGM Report. Programme Cordet 1982. $83 \mathrm{NOU} 005$.

Bache, J.J. 1981. Les minéralisations aurifères de Nouvelle-Calédonie. Rapport BRGM 01 NOU 002.

Bache, J.J. \& Wilhelm, E. 1980. Inventaire des ressources minières de la Nouvelle-Calédonie Résultats de la phase préliminaire. BRGM report, SGN/GMX n594, 1-104.

Bailly, L., Ambrosi, J.P., Barbarand, J., Beauvais, A., Cluzel, D., Lerouge, C., Prognon, C., Quesnel, F., Ramanaïdou, E., Ricordel-Prognon, C., Ruffet, G., Sevin, B., Wells, M. \& Yans, J. 2014. Projet NICKAL : Typologie des latérites de Nouvelle-Calédonie et facteurs de concentration de Co et Ni. rapport final, BRGM/RP-63 482, 1-402.

Baksheev, I.A., Savina, D.N. \& Kudryavtseva, O.E. 1999. Alteration carbonates as zonation indicators, the Berezovsk gold deposit, Russia. in: CJ Stanley et al, eds, Mineral Deposits, Processes to Processing. Balkema, Rotterdam, 1379-1382.

Ballance, P.F. 1993. The paleo-Pacific, post-subduction, passive margin thermal relaxation sequence (Late Cretaceous-Paleogene) of the drifting New Zealand continent. In: South Pacific sedimentary basins. Sedimentary basins of the World, 2, Elsevier, Amsterdam,, 93-110.

Baltzer, F. 1965. Étude sédimentologique du marais de Mara (côte ouest de la Nouvelle-Calédonie) et de formations quaternaires voisines. Ph D. thesis memoir, Laboratoire de sédimentologie, Orsay, Paris. In: Expédition française sur les récifs coralliens de la Nouvelle-Calédonie. Edition de la fondation Singer-Polignac. Paris 1970, IV, 1-148.

Barnes, I. \& O'Neil, J. 1969. The relationship between fluids in some fresh alpine-type ultramafics and possible modern serpentinization, Western United States. Geological Society America Bulletin, 80, 1947-1960.

Baumann, F. 2012. Environmental exposure to carcinogenic fibers due to Serpentinite paved roads in new caledonia: lessons in Environmental epidemiology and in prevention. Cordilleran Section - 108th Annual Meeting, Environmental Geochemistry I.

Baumann, F., Buck, B.J., Metcalf, R.V., McLaurin, B.T., Merkler, D.J., Carbone, M. 2015. The Presence of Asbestos in the Natural Environment is Likely Related to Mesothelioma in Young Individuals and Women from Southern Nevada. Journal of Thoracic Oncology, 10, 731-737.

Baumann, F., Maurizot, P, Mangeas, M, Ambrosi, JP, Douwes, J, Robineau, B. 2011. Pleural mesothelioma in New Caledonia: associations with environmental risk factors. Environmental Health Perspective, 119, 695-700.

Baumann, F., Rougier, Y., Ambrosi, J.P. \& Robineau, B.P. 2007. Pleural mesothelioma in New Caledonia: An acute environmental concern. Cancer detection and prevention, 31, 70-76. 
Beaudou, A.G., Fromaget, M., Podwojewski, P., Bourdon, E., Le Martret, H. \& Blavet, D. 1983. Cartographie typologique des sols. Méthodologie. ORSTOM-Territoire de la Nouvelle-Calédonie et dépendances, 1-31.

Ben Aissa, F., Postec, A., Erauso, G., Payri, C., Pelletier, B., Hamdi, M., Fardeau, M.L. \& B., O. 2015 Characterization of Alkaliphilus hydrothermalis sp. nov., a novel alkaliphilic anaerobic bacterium, isolated from a carbonaceous chimney of the Prony hydrothermal field, New Caledonia.

Extremophiles, 19, 183-188.

Bernat, M., Loubet, M. \& Baumer, A. 1991. Sur l'origine des phosphates de l'atoll coralien de Nauru. Oceanologica Acta, 14, 325-331.

Black, P. 1995. High-Si rhyolites and shoshonitic volcanics; a late Cretaceous bimodal association, Nouméa basin, New Caledonia. Pacrim'95 Congress, Auckland 11/95, Proceedings Vol, 55-58.

Black, P., Maurizot, P., Ghent, E. \& Stout, M. 1993. Mg-Fe carpholites from aluminous schists in the Diahot region and implications for preservation of high-pressure/low-temperature schists, northern New Caledonia. Journal of Metamorphic Geology, 11, 455-460.

Black, P.M. 2004. Cornishmen and Convicts Mining and European settlements of the Diahot, northern New Caledonia. Thesis memoir for the degree of MsC of Arts in History. The University of Auckland, 1153.

Blake, R. 1996. Interpretation report on the Gouaro seismic survey, PRA 436 - New Caledonia. Report prepared for Victoria Petroleum N.L., 1-23.

Bolton, B.R., Ostwald, J. \& M., M. 1986. Precious metals in ferromanganese crusts from the Southwest Pacific. Nature, 320, 518-520.

Bourrouilh - Le Jan, F.G. 1989. The oceanic karst: Modern bauxite and phosphate ore deposits on the high carbonate islands (So-called "Uplifted atolls") of the Pacific Ocean. Development in Eatrh surface processes, 1, 443-471.

Bourrouilh - Le Jan, F.G. 1992. Evolution des karsts océaniens (karsts, bauxites et phosphates). Karstologia, 19, 31-50.

Bourrouilh - Le Jan, F.G. 1996. Plates-formes carbonatées et atolls du centre et sud Pacifique : Stratigraphie, sédimentaologie, minéralogie et géochimie. Diagenèse et émersions : Aragonite, calcite, dolomite, bauxite et phosphate. Document du BRGM. Editions du BRGM., 249, 1-365.

BRGM. 1980. Inventaire des ressources minières du territoire de la Nouvelle-Calédonie, Rapport annuel. BRGM report 88 NCL 214, 1-38.

BRGM. 1981. Inventaire des Ressources Minières du Territoire de Nouvelle-Calédonie. Fichier des indices recensés, 1979 - 1980. BRGM Report 81 NOU 001. 
BRGM. 1982. Rapport sur la campagne 1982. Proposition de programme pour l'année 1983. Inventaire Minier de la Nouvelle-Calédonie; rapport 82 NOU 011, 1-83.

BRGM. 1986a. Inventaire des ressources minières de la Nouvelle-Calédonie, Rapport de campagne 1986 et programme 1987. BRGM report 86 NCL 167, 1-208.

BRGM. 1986b. Inventaire des ressources minières du territoire de la Nouvelle-Calédonie, Nakety, Gîte antimono-aurifère filonien. BRGM report 86 NCL 167, 1-208.

BRGM. 1986c. Le gite à plomb-zinc-argent de Meretrice, rapport final. Inventaire des ressources minières du territoire de la Nouvelle-Calédonie. BRGM report 86 NCL 114, 23.

BRGM. 1987a. Gisements du Diahot, Etat des connaissances. Inventaire des ressources minières du territoire de Nouvelle-Calédonie. Rapport BRGM 87 NCL 103, 1-125.

BRGM. 1987b. Inventaire des ressources minières du territoire de la Nouvelle-Calédonie, Le gite Koum D1 et son environnement. BRGM Report 87 NCL 237, 1-44.

BRGM. 1987c. Inventaire des ressources minières du territoire de la Nouvelle-Calédonie, Rapport de la campagne 1987, programme 1988. BRGM Report 87 NCL 236, 1-44.

BRGM. 1988. Inventaire des ressources minières du territoire de la Nouvelle-Calédonie, Rapport provisoire de l'annee 1988. BRGM report 88 NCL 214, 1-123.

BRGM. 1990a. Inventaire des ressources minières du territoire de la NC, campagne 89 et programme 90, rapport de synthèse. BRGM report $R 30621 \mathrm{NCL} D A M 90,1-45$.

BRGM. 1990b. Programme Sysmin 1989-90 or Nouvelle-Calédonie, Etude de la cible Comète, Rrapport de 1er exercice. BRGM Report, 1-85.

BRGM. 1990c. Programme Sysmin 1989-90, Or Nouvelle-Calédonie, Note de synthèse. BRGM report A 434, 1-18.

BRGM. 1990d. Programme Sysmin 1989-90, or Nouvelle-Calédonie, Prospection stratégique et tactique. BRGM report $R 1990$ 1, 1-18.

Briggs, R.M. 1975. Structure, metamorphism and mineral deposits in the Diahot region, northern New Caledonia. PhD Thesis, Univesity of Auckland, New Zealand, 486.

Briggs, R.M. 1977. High-pressure metamorphism of stratiform sulphide deposits from the Diahot region New Caledonia. Mineral ium Depositaum Deposita, 12, 263-279.

Briggs, R.M., Lillie, A.R. \& Brothers, R.N. 1978. Structure and high-pressure metamorphism in the Diahot region northern New Caledonia. Bulletin du BRGM, Section IV, 3, 171-189. 
Buckman, S. \& Ashley, P. 2010. Silica-carbonate (listwanites) related gold mineralisation associated with epithermal alteration of serpentinite bodies. Conference: New England Orogen, Armidale, NSW, Australia: University of New England, 94-105.

Burns, R.E. \& Andrews, J.E. 1973. Site 208. Initial Report of the Deep Sea Drilling Project, 21, 271331.

Burns, R.E., Andrews, J.E., Van der Lingen, G.J., Churkin, M., Davies, J.H., Dumitrica, P., Edwards, A.R., Galehouse, J.S., Kennett, J.P. \& Packham, G.H. 1973. Regional aspects of deep sea drilling in the Southwest Pacific, Lithostratigraphy of Eight Drill Sites in the Southwest Pacific. Preliminary Results of the Deep Sea Drilling Project, 21.

Cameron, W.E. 1989. Contrasting boninite - tholeiite associations from New Caledonia. In: Boninites, edited by A.J. Crawford. Unwin Hyman, Boston, Mass, 314-336.

Carne, R.C. \& Cathro, R.J. 1982. Sedimentary exhalative (SEDEX) zinc-silver-lead deposits, Nortern Canadian Cordillera. Canadian Institute of Mining and Metallurgy Bulletin, 75.

Chavagnac, V., Ceuleneer, G., Monnin, C., Lansac, B., Hoareau, G. \& Boulart , C. 2013. Mineralogical assemblages forming at hyper-alkaline warm springs hosted on ultramafic rocks: a case study of Oman and Ligurian ophiolites. Geochemestry. Geophysics. Geosystems, 14, 2474-2495.

Chavagnac, V., Monnin, C., Ceuleneer, G., Boulart, C. \& Hoareau, G. 2014. Characterization of hyperalkaline fluids produced by low temperature serpentinization of mantle peridotites in 20 the Oman and Ligurian ophiolites. Geochemestry. Geophysics. Geosystems, 14, 2496-2522.

Chiron, J.C., Eberle, J.M. \& Letalenet, J. 1986. Rapport de l'inventaire des ressources minières du territoire de la Nouvelle- Calédonie, campagne 1985. BRGM Report 86 NCL 134, 1-43.

Clarke, G.L., Aitchison, J.C. \& Cluzel, D. 1997. Eclogites and blueschists of the Pam Peninsula, NE New Caledonia: a reappraisal. Journal of Petrology, 38, 843-876.

Cluzel, D., Adams, C.J., Maurizot, P. \& Meffre, S. 2011. Detrital zircon records of Late Cretaceous syn-rift sedimentary sequences of New Caledonia: An Australian provenance questioned. Tectonophysics, 501, 17-27, doi: 10.1016/j.tecto.2011.01.007.

Cluzel, D., Aitchison, J., Clarke, G., Meffre, S. \& Picard, C. 1994. Point de vue sur l'évolution tectonique et géodynamique de la Nouvelle-Calédonie (Pacifique, France). Comptes rendus de l'Académie des sciences. Série 2. Sciences de la terre et des planètes, 319, 683-690.

Cluzel, D., Aitchison, J., Clarke, G., Meffre, S. \& Picard, C. 1995a. Dénudation tectonique du complexe à noyau métamorphique de haute préssion d'âge tertiaire (Nord de la Nouvelle-Calédonie, Pacifique, France). Données cinématiques. Comptes rendus de l'Académie des sciences. Série 2. Sciences de la terre et des planètes, 321, 57-64.

Cluzel, D., Aitchison, J.C., Clarke, G.L., Meffre, S. \& Picard, C. 1995b. Dénudation tectonique du complexe à noyau métamorphique de haute pression d'âge tertiaire (Nord de la Nouvelle-Calédonie, 
Pacifique, France). Données cinématiques. Comptes Rendus de l'Académie des Sciences, 321, 5764.

Cluzel, D., Aitchison, J.C. \& Picard, C. 2001. Tectonic accretion and underplating of mafic terranes in the Late Eocene intraoceanic fore-arc of New Caledonia (Southwest Pacific): geodynamic implications. Tectonophysics, 340, 23-59, doi: 10.1016/S0040-1951(01)00148-2.

Cluzel, D., Bosch, D., Paquette, J.L., Lemennicier, Y., Montjoie, P. \& Ménot, R.P. 2005. Late Oligocene post-obduction granitoids of New Caledonia : A case for reactivated subduction and slab break-off. The Island Arc, 14, 254-271.

Cluzel, D., Clarke, G. \& Aitchison, J. 1995c. Northern New Caledonia high pressure metamorphic core complex from contintenal subduction to extensional exhumation. Pacrim Congress 1995, Exploring the Rim, Australian Institute of Mining and Metallurgy Publication Series, 129-134.

Cluzel, D., Maurizot, P., Collot, J. \& Sevin, B. 2012. An outline of the Geology of New Caledonia ; from Permian - Mesozoic Southeast Gondwanaland active margin to Cenozoic obduction and supergene. Episodes, 72-86.

Cluzel, D., Meffre, S., Maurizot, P. \& Crawford, A.J. 2006. Earliest Eocene (53 Ma) convergence in the Southwest Pacific: evidence from pre-obduction dikes in the ophiolite of New Caledonia. Terra Nova, 18, 395-402, doi: 10.1111/j.1365-3121.2006.00704.x.

Colleau, A. 1984. Inventaire des calciares marbriers de Nouvelle-Calédonie. Internal report: Service des Mines et de l'Energie. Nouméa.

Colleau, A., Walter, J. \& Ziserman, A. 1978. Le mercure de la concession Ethiops, NouvelleCalédonie. Proposition à la Direction de Nouméa sur le prospect de Mme Fruitée. Rapport interne BRGM, Nouméa.

Collot, J. 2009. Evolution géodynamique du domaine Ouestoffshore de la Nouvelle-Calédonie et de ses extensions vers la Nouvelle Zélande. Ph.D. thesis, Université de Bretagne occidentale-Brest.

Collot, J., Herzer, R., Lafoy, Y. \& Geli, L. 2009. Mesozoic history of the Fairway- Aotea Basin: Implications for the early stages of Gondwana fragmentation. Geochemistry, Geophysics, Geosystems, 10.

Constantinou, G. 1980. Metallogenesis Associated with the Troodos Ophiolite. in Panayioutou, A., Editor, Ophiolites, International Ophiolite Sym· posium, Cyprus 1979, 663-667.

Cook, R.A. 1987. The geochemistry of oils of Taranaki and West Coast Region. New Zealand Oil Exploration Conference, New Zealand Ministry of Energy and Pacific Seismic Group.

Cox, M.E., Launay, J. \& Paris, J.P. 1982. Geochemistry of low temperature geothermal systems in New Caledonia. Proc. Pacific Geothermal Conference. University of Auckland, New Zealand. Part 2, 453-459. 
Danyushevsky, L.V., Crawford, A.J., Leslie, R.L., Tetroeva, S. \& Falloon, T.J. 2006. Subductionrelated magmatism along the southeast margin of the North Fiji backarcback-arc basin. Moscow, Geochemica et Cosmochimica Acta, 15th Annual V M Goldschmidt Conference, 69, A633.

Delvinquier, B. \& Jegat, P. 2001. Historique des mines de phosphate en Nouvelle-Calédonie : L'exploitation du Guano aux Îles Chesterfiled, Surprise, Walpole et Tiga. Bulletin de la Société d'Etudes Historiques de Nouvelle-Calédonie, 128.

Dill, H.G. 2010. The "chessboard" classification scheme of mineral deposits Mineralogy and geology from Al to Zr. Earth-Science Reviews, 100, 1-420.

Ducrocq, M., Collot, J., Rouillard, P., Rivaton, A. \& Farman, R. 2012. Programme ZoNéCo 2006-2010, Bilan et perspective. 1-170.

Eberlé, J.M. 1982. Etude complémentaire de l'indice de barytine de l'îlot Tanlai, Nouvelle-Calédonie. BRGM Report 82 NOU 001, 1-14.

Espirat, J.J. 1957. Mission charbon. Foni Boya. Rapport de 1er sondage. BUMIFOM (Bureau Minier de la France d'Outre Mer) Report.

Espirat, J.J. 1958. Mission Charbon. Rapport sur l'étude de détail des zones extension Fony Boya Fony Mendjele. BUMIFOM (Bureau Minier de la France d'Outre Mer) Report.

Espirat, J.J. \& Millon, R. 1971. Carte géologique à l'échelle du 1 / 50 000. Notice explicative sur la feuille Poum. Territoire de la Nouvelle-Calédonie. Bureau de Recherches Géologiques et Minières. Paris, 1-7.

Exon, N.F., Lafoy, Y., Hill, P.J., Dickens, G.R. \& Pecher, I. 2007. Geology and petroleum potential of the Fairway Basin in the Tasman Sea. Australian Journal of Earth Sciences, 54, 629-645, doi: $10.1080 / 08120090701305194$.

Faivre, J.P., Poirier, J. \& Routhier, P. 1955. Géographie de la Nouvelle-Calédonie. Nouvelle édition latines. Paris. Publications du centenaire de la Nouvelle-Calédonie, 1-311.

Fikri, A. 1991. Contribution à l'étude de la géochimie organique des phosphates insulaires. Implication dans la phosphatogenèse. Ph D.thesis memoir. Université d'Orléans, 1-202.

Folcher, N., Sevin, B., Quesnel, F., Lignier, V., Allenbach, M., Maurizot, P. \& Cluzel, D. 2015. Neogene terrestrial sediments: a record of the post-obduction history of New Caledonia. Australian Journal of Earth Sciences: An International Geoscience Journal of the Geological Society of Australia, doi: DOI: 10.1080/08120099.2015.1049207.

Fouquet, Y. \& Lacroix, D. 2012. Les ressources minérales marines profondes, Étude prospective à l'horizon 2030. Editions Quae, 1-176. 
France, R. 2000. PRA 436, New Caledonia: Cadart-1 \& Cadart-1st Final Well Report (Vol. 1: Text and enclosures, 66 p.; Vol. 2: Appendices), . Victoria Petroleum N.L. Report. Direction de I'Industrie des Mines et de l'Energie de Nouvelle-Calédonie, A.C.N. 008942827.

Garcin, M. 2009. Exploitation des granulats en lit vif en Nouvelle Calédonie : le cas de la rivière Tontouta, Rapport final. Bureau de Recherches Géologiques et Minières report BRGM/RP-57268-FR, $1-71$.

Garcin, M. 2010. Exploitation des granulats en lit vif des cours d'eau de la Grande Terre, NouvelleCalédonie. Bureau de Recherches Géologiques et Minières report BRGM/RP-58531-FR, 1-114.

Garcin, M. \& Lesimple, S. 2013a. Identification des rivières sur-engravées de la Grande-Terre (Nouvelle-Calédonie) - Aptitude à l'exploitation pour granulats. Bureau de Recherches Géologiques et Minières report BRGM/RP-62297-FR, 1-95.

Garcin, M. \& Lesimple, S. 2013b. Identification des rivières sur-engravées de la Grande-Terre (Nouvelle-Calédonie) - Aptitude à l'exploitation pour granulats. Bureau de Recherches Géologiques et Minières report BRGM/RP-62297-FR.

Garnier, J. 1867a. Essai sur la géologie et les ressources minérales de la Nouvelle-Calédonie. Annales des Mines, 6, 1_92.

Garnier, J. 1867b. Note sur la garniérite. Comptes Rendus de l'Académie des Sciences, 86, 684-686.

Garnier, J. 1867c. Note sur la géologie de la Nouvelle-Calédonie. Bulletin de la Societe Geologique de France, 2, 438-451.

Garnier, J. 1871. Voyage autour du monde, La Nouvelle-Calédonie (côte orientale). Plon Ed., Paris, 1364.

Glasser, E. 1904. Rapport à Mr. le Ministre des Colonies sur les richesses minérales de la NouvelleCalédonie. Extraits des Annales des Mines, Paris, Dunod Ed., 10.

Goldberg, M., Goldberg, P., Leclerc, A., Chastang, J.F., Marne, M.J., Dubourdieu, D. 1994. A 10-year incidence survey of respiratory cancer and a case-control study within a cohort of nickel mining and refining workers in New Caledonia. Cancer Causes Control, 5, 15-25.

Goldberg, P., Goldberg, M, Marne, MJ, Hirsch, A, Tredaniel, J. 1991. Incidence of pleural mesothelioma in New Caledonia: a 10-year survey (1978-1987). Arch Environ Health, 46, 306-309.

Goldberg, P., Luce, D., Billon-Galland, M., Quénel, P., Salomon-Nerkiriai, C., Nicolau, J., Brochard, P. \& Goldberg, M. 1995. Rôle potentiel de l'exposition environmentale et domestique à la trémolite dans le cancer de la plèvre en Nouvelle Calédonie. Revue d'épidémiologie et de santé publique, 43, 444450.

Goldberg, P., Luce, D., Billon-Gailland, M.A., Quénel, P., Salomon-Nekiriai, C., Nicolau, J. 1995. Identification d'un excès de risque de cancer de la plèvre en Nouvelle-Calédonie lié à l'exposition 
environnementale et domestique à la trémolite. Revue Epidemiologique et de Santé Publique, 43, 444-450.

Gonord, H. 1968. Remarques sur les séries métamorphiques de la Nouvelle-Calédonie centrale, conséquences structurales et paléogéographiques. Compte Rendus de la Societé Géologique Française, 9, 335-337.

Grandperrin, R., Richer de Forges, B. \& Auzende, J.M. 1997. Marine Resources of New Caledonia The Zonéco Programme. Nouméa, New Caledonia. 1-91.

Guillon, J.H. 1972. Les règles de distribution des sulfures cupro-nickélifères dans les massifs péridotitiques de NC, modèle zonéographique. Comptes Rendus de l'Académie des Sciences, 274, 3168-3171.

Guillon, J.H. \& Trescases, J.J. 1976. Carte géologique à l'échelle du 1 / 50000 et notice explicative, feuille Saint-Louis. BRGM - Nouvelle-Calédonie, 1-42.

Haas, J.O. 1932. Rapport à Monsieur le Ministre des Colonies sur les ressources de la NouvelleCalédonie en combustibles liquides. Rapport inédit S.R.E.P.N.C.

Habault, C. 1987. Compte rendu de la visite a Walpole le 11 Avril 1987. Internal Report, Direction de I'Industrie, des Mines et de l'Energie de Nouvelle-Calédonie, Nouméa, 1-14.

Hatipoglu, M., Ören, U. \& ar Kibici, Y. 2011. Micro-Raman spectroscopy of gem-quality chrysoprase from the Biga-Çanakkale region of Turkey. Journal of African Earth Sciences, 61, doi:

10.1016/j.jafrearsci.2011.08.002.

Herzer, R.H., Sykes, R., Killops, S.D., Funnel, R.H., Burggraf, D.R., Townend, J., Raine, J.I. \& Wilson, G.J. 1999. Cretaceous carbonaceous rocks from the Norfolk Ridge rocks system, Southwest Pacific: Implications for regional petroleum potentiel. New Zealand Journal of Geology and Geophysics, 42, 57-73.

Heurteau, E. 1876. Rapport au ministre de la marine et des colonies sur la constitution géologique et les richesse minérales de la Nouvelle-Calédonie. Paris, Dunod Ed.

Jacob, M. 1985. Etude géologique, minéralogique et géochimique des anomalies en As, Sb, Au et W et des indices minéralisés liés aux fractures régionales de la côte est de la Nouvelle-Calédonie. Thèse 3ème cycle, Toulouse, 1-163.

Jehl, C. 1995. Les mattes algaires cyanobactériennes (kopara) des atolls des Tuamotu : biochimie, productivité et signification écologique. Insertion dans un modèle de phosphatogenèse. $P h D$. thesis memoir. ORSTOM - UFP.

Kelemen, P.B. \& Matter, J. 2008. In situ carbonation of peridotite for CO 2 storage. Proceedings of the National Academy of Science of the United States of America, 105, 17295-17300, doi:

doi10.1073?pnas.0805794105. 
Kelley, D.S., Karson, J.A., Blackman, D.K., Fruh-Green, G.L., Butterfield, D.A., Lilley, M.D., Olson, E.J., Schrenk, M.O., Roe, K.K., Lebon, G.T. \& Rivizzigno, P. 2001. An off-axis hydrothermal vent field near the Mid-Atlantic Ridge at $30^{\circ}$ N. Nature, 412, 145-149.

Killops, S.D., Woolhouse, A.D., Weston, R.J. \& Cook, R.A. 1994. Geochemical appraisal of oil generation in the Taranaki Basin, New Zealand. American Association of Petroleum Geologists Bulletin, 78, 560-585.

King, P.R., Naish, T.R., Browne, G.H., Field, B.D. \& Edbrooke, S.W. 1999. Cretaceous to Recent Sedimentary Patterns in New Zealand. GNS Folio 1. Institute of Geological and Nuclear Sciences Ltd, Lower Hutt, Folder with 35 pp., 1.

King, P.R. \& Thrasher, G.P. 1996. Cretaceous-Cenozoic Geology and Petroleum Systems of the Taranaki Basin, New Zealand. GNS Monograph 13. Institute of Geological and Nuclear Sciences Ltd, Lower Hutt.

Klau, W. \& Large, D.E. 1980. Submarine exhalative $\mathrm{Cu}-\mathrm{Pb}-\mathrm{Zn}$ deposits, a discussion of their classification and metallogenesis. Geologische Jahrbuch, D 40, 13-58.

Klingelhoefer, F., Lafoy, Y., Collot, J., Cosquer, E., Géli, L., Nouzé, H. \& Vially, R. 2007. Crustal structure of the basin and ridge system west of New Caledonia (southwest Pacific) from wide-angle and reflection seismic data. Journal of Geophysical Research, 112, doi: 10.1029/2007jb005093.

Koch, P. 1957a. Iles coraliennes et minéralisation en phosphate. Nouvelle-Calédonie et dépendances. In : Rapport annuel Service des Mines et Géologie. Nouméa. , 7.

Koch, P. 1957b. Rapport préliminaire sur la reconnaissance géologique de l'île de Tiga (Loyauté), 7-8 juillet 1957 et les îles Doudoune et Leliogat (Loyauté), 2-3 septembre 1957. Rapport Service des Mines \& de l'Energie, 1-7.

Koch, P. 1957c. Reconnaissance géologique de la formation à charbon aux environs de Houailou. Nouvelle-Calédonie. Service des Mines. Section Géologie.

Koch, P. 1957d. Reconnaissance géologique des Îles Chesterfield (24 - 28 septembre1957). Rapport du Service des Mines et de la Géologie, 1-7.

Koch, P. 1958a. Géologie et minéralisation de l'île de Tiga - Prospection systématique pour phosphates. Rapport interne Service des Mines.

Koch, P. 1958b. Iles Loyauté. Bulletin géologique de la Nouvelle-Calédonie, 1, 1617.

Koch, P. 1958c. Les ressources minérales de la Nouvelle-Calédonie. Rapport interne du Service des Mines, 1-34.

Koch, P. 1958d. Sources thermales de Nouvelle-Calédonie et captage des sources de La Crouen. Bulletin géologique de la Nouvelle-Calédonie, 1, 189-203. 
Koski, R.A. \& Hein, J.R. 2003. Stratiform Barite Deposits in the Roberts Mountains Allochthon, Nevada: A Review of Potential Analogs in Modern Sea-Floor Environments. USGNS. Chapter H of Contributions to Industrial-Minerals Research, Bulletin 2209-H, 1-21.

Kroeger, K.F. \& Funnel, R. 2011. Generation and flow-path migration modelling of the Fairway Basin, New Caledonia. GNS-Science consultancy report, 2011/349.

Lacroix, A. 1942. Les péridotites de la Nouvelle-Calédonie, leurs serpentines et leurs gîtes de nickel et cobalt, les gabbros qui les accompagnent. Mémoires de l'Académie des Sciences de l'Institut de France., 66, 1-143.

Lafoy, Y., Missègue, F., Cluzel, D. \& Le Suave, R. 1996. The Loyalty-New Hebrides arc collision; effects on the Loyalty ridge and basin system, Southwest Pacific (first results of the ZoNeCo Programme). In: Seafloor mapping in the West, Southwest and South Pacific; results and applications. Auzende J.M. (editor); Collot J.Y. (editor), D. Reidel Publishing Company. Dordrecht,Netherland. Marine Geophysical Researches., 18, 337.

Lafoy, Y., Pelletier, B., Auzende, J.-M., Missègue, F. \& Mollard, L. 1994. Tectonique compressive cénozoïque sur les rides de Fairway et Lord Howe, entre Nouvelle-Calédonie et Australie. Comptes Rendus de l'Academie des Sciences Serie II, 319, 1063-1069.

Lang, J.R., Baker, T., Hart, C.J.R. \& Mortensen, J.K. 2000. An exploration model for intrusion-related gold systems. Society of Economic Geology Newsletter, 40.

Large, D.E. 1980. Geological parameters associated with sediment-hosted, submarine exhalative PbZn deposits: an empirical model for mineral exploration. Geologisches Jahrbuch, D 40, 59-129.

Large, R.R. 1992. Australian volcanic-hosted massive sulfide deposits: features, style and genetic models. Economic Geology, 87, 471-510.

Latham, M., Quantin, P. \& Aubert, G. 1978. Etude des sols de la Nouvelle-Calédonie. Nouvel essai sur la classification, la caractérisation, la pédogenèse et les aptitudes des sols de Nouvelle-Calédonie. Carte pédologique de la Nouvelle-Calédonie à 1/ 100 000. ORSTOM, Paris, 1-138.

Launay, J. \& Fontes, J.-C. 1985. Les sources thermales de Prony (Nouvelle-Caledonie) et leurs precipites chimiques. Exemple de formation de brucite primaire. Géologie de la France, 1, 83-100.

Laurent, E. 2011. Caractérisation et cartographie du substrat des fonds marins de la ZEE de la Nouvelle-Calédonie (Sud-Ouest Pacifique). M. Sc. engineering school thesis report, Institut LaSalle Beauvais, 482, 1-128.

Laznicka, P. 2006. Giant Metallic Deposits: Future Sources of Industrial Metals. Springer.

Le Berre, P. 1990a. Invenaire des roches et minéraux industriels de la Province Nord (Nouvelle-

Calédonie). Recherche de gisements de calcaire à ciment dans la région de Pouembout. Bureau de Recherches Géologiques et Minières report R. 31 976, 1-75. 
Le Berre, P. 1990b. Inventaire des roches et minéraux industriels de la Province Nord (NouvelleCalédonie); étude technico-économique préliminaire. BRGM Report, R.31 482 NCL 4S 90.

Le Berre, P. 1991. Inventaire des roches et minéraux industriels de la Province Nord, recherche de gisements de roches ornementales. BRGM Report, R 34457.

Le Berre, P. \& Maurizot, P. 1992. Reconnaissnace géologique de matèriaux pour ciment dans la région de Népoui. A2EP internal report.

Lebret, P. \& Maurizot, P. 2007. Aide à la mise en place d'un programme matériaux et carrières à la Direction de l'Industrie, des Mines, et de l'Energie, Nouvelle-Calédonie, : propositions - Rapport Final. Bureau de Recherches Géologiques et Minières Report, RP-55924-FR, 1-212.

Lemennicier, Y., Cluzel, D. \& Ménot, R.P. Geodynamic setting of early miocene granidioritic intrusives and associated epi,mesothermal gold depposits. Southeast New Caledonia. Poster.

Lemennicier, Y., Cluzel, D. \& Ménot, R.P. 1998. Geodynamic setting of mid-Oligocene granodioritic intrusives and associated epi-mesothermal gold deposits. Southeast New Caledonia. Congress SOPAC Fiji '98 Abstracts.

Lemennicier, Y., Cluzel, D. \& Ménot, R.P. 1999. Geodynamic setting of early miocene granodioritic intrusives in Southeast New-Caledonia. EUG 10, 28th March - 1st April, 1999, Strasbourg, France. Abstracts. Symposium F03, Arc-Continent Collisions Past and Present, 4.

Lessard, R., Reed, D, Maheux, B, Lambert, J. 1978. Lung Cancer in New Caledonia. A Nickel Smelting Island. J Occup Med, 20, 815-817.

Likhoidov, G.G., Plyusnina, L.P. \& Shcheka, Z.A. 2007. The behavior of gold during listvenitization: experimental and theoretical simulation. Doklady Earth Sciences, 415, 723-726.

Luce, D., Billon-Galland, M.-A., Bugel, I., Goldberg, P., Salomon, C., Févotte, J. \& Goldberg, M. 2004. Assessment of environmental and domestic exposure to tremolite in New Caledonia. Archives of Environmental Health: An International Journal, 59, 91-100.

Luce, D., Bugel, I, Goldberg, P, Goldberg, M, Salomon, C, Billon-Galland, MA. 2000. Environmental exposure to tremolite and respiratory cancer in New Caledonia: a case-control study. Am J Epidemiol, $151,259-265$.

Luyendyk, B.P. 1995. Hypothesis for Cretaceous rifting of east Gondwana caused by subducted slab capture. Geology, 23, 373-376.

Maurizot, P. 1981. Inventaire des ressources minières du Territoire de Nouvelle-Calédonie. Fichier des indices rensés en 1979 - 1980. BRGM Report, Nouméa, 81 NOU 001, 1-145.

Maurizot, P. 2005. Valorisation et validation du sondage de référence Cadart 1-Nouvelle-Calédonie. Rapport BRGM/RP-54 118-FR. Orléans, France, BRGM. 
Maurizot, P. 2011. First sedimentary record of the pre-obduction convergence in New Caledonia : formation of an Early Eocene accretionary complex in the north of Grande Terre and emplacement of the 'Montagnes Blanches ' nappe. Bulletin de la Société Géologique Française, 182, 6, 479-491.

Maurizot, P. 2013. Palaeocene age for the Adio Limestone, New Caledonia: stratigraphic and regional context. New Zealand Journal of Geology and Geophysics, 56, 16-26, doi:

$10.1080 / 00288306.2012 .735677$.

Maurizot, P. 2014. Evolution and sedimentation in a forebulge environment: example of the Late Eocene Uitoé Limestone, New Caledonia, Southwest Pacific. New Zealand Journal of Geology and Geophysics, 57, 390-401, doi: 10.1080/00288306.2014.938085.

Maurizot, P. \& Bouysse, P. 1989. Recherche de gisements de sable et de méthodes d'extraction pour l'amélioration des plages dans la zone de Nouméa. Bureau de Recherches Géologiques et Minières, Réf. 89 NCL 167, 1-45.

Maurizot, P., Cabioch, G., Fournier, F., Leonide, P., Sebih, S., Rouillard, P., Montaggioni, L., Collot, J., Martin-Garin, B., Chaproniere, G., Braga, J.C. \& Sevin, B. 2016. Post-obduction carbonate system development in New Caledonia (Népoui, Lower Miocene). Sedimentary Geology, 331, 42-62, doi: 10.1016/j.sedgeo.2015.11.003.

Maurizot, P., Cluzel, D., Meffre, S., Campbell, H.J., Collot, J. \& Sevin, B. in press. Pre-Late Cretaceous basement terranes of the Gondwana active margin. Geological Society, London memoir: New Caledonia: geology, geodynamic evolution, and mineral resources, N. Mortimer ed., Chapter 3.

Maurizot, P., Eberlé, M., Habault, C. \& Tessarollo, C. 1989. Carte Géologique à l'échelle du $1 / 50000$ et notice explicative: feuille Pam-Ouégoa. Territoire de la Nouvelle-Calédonie - Bureau de Recherches Géologiques et Minières, 1-81.

Maurizot, P. \& Gasc, P. 1986. Carte géologique et d'aptitude à l'aménagement de la zone urbaine de Nouméa à l'échelle du 25000 . Territoire de la Nouvelle-Calédonie. Bureau de Recherches Géologiques et Minières. Nouméa, DIMENC/SGNC. Orléans, BRGM, 1-45.

Maurizot, P. \& Lafoy, Y. 2003. Carte géologique de Nouvelle-Calédonie (1 / 50 000), feuille Maré (Tiga, Walpole, Dudun et Leliogat), Îles Loyauté. BRGM Report/RP51 857 - FR.Service Géologique de Nouvelle-Calédonie. Bureau de Recherches Géologiques et Minières., 1-140.

Maurizot, P. \& Le Berre, P. 1991. Reconnaissance géologique des calcaires marbriers de la région de Koumac. Bureau de Recherches Géologiques et Minières report BRGM 455/91, 1-24.

Maurizot, P. \& Le Berre, P. 1992. Reconnaissance géologique des calcaires marbriers de la région de Koumac (Nouvelle-Calédonie); Note additionnelle au rapport BRGM 455/91. Bureau de Recherches Géologiques et Minières report 92 N 066, 1-16.

Meffre, S. 1995. The Development of Island-Arc related ophiolites and Sedimentary sequences in New Caledonia. Ph D. thesis, University of Sydney, 1-258. 
Meffre, S., Aitchison, J.C. \& Crawford, A.J. 1996. Geochemical evolution and tectonic significance of boninites and tholeiites from the Koh Ophiolite, New Caledonia. Tectonics, 15, 67-83.

Monnin, C., Chavagnac, V., Boulart, C., Ménez, B., Gérard, M., Gérard, E., Quéméneur, M., Erauso, G., Postec, A., Guentas-Dombrowski, L., Payri, C. \& Pelletier, B. 2014. The low temperature hyperalkaline hydrothermal system of the Prony bay (New Caledonia). Biogeosciences Discussion, 11, 6221-6267, doi: doi:10.5194/bgd-11-6221-2014.

Montagionni, L. 1985. Makatea island, Tuamotu Archipelago. 5th International Reef Congress, Tahiti, Guide Book.

Mortimer, N. 2008. Zealandia. in Spencer, J.E., and Titley, S.R., eds., Circum-Pacific Tectonics, Geologic Evolution, and Ore Deposits: Tucson, Arizona, Arizona Geological Society, Digest, 22, $227-$ 233.

Mosier, D.L., Berger, V.L. \& Singer, D.A. 2009. Volcanogenic Massive Sulfide Deposits of the WorldDatabase and Grade and Tonnage Models. USGS Open-File Report 2009-1034.

Nicholson, K.N.N., Maurizot, P., Black, P.M.M., Picard, C., Simonetti, A., Stewart, A. \& Alexander, A. 2011. Geochemistry and age of the Nouméa Basin lavas, New Caledonia: Evidence for Cretaceous subduction beneath the eastern Gondwana margin. Lithos, 125, 659-674, doi:

10.1016/j.lithos.2011.03.018.

Noël, Y. 1992. Projet de cimenterie à Népoui (Nouvelle-Calédonie). Approche économique sommaire. bureau de Recherches Géologiques et Minières report $R 36$ 114, 1-60.

Noesmoen, A. 1957a. Mission charbon. Bassin de Moindou. BUMIFOM (Bureau Minier de la France d'Outre Mer) Report.

Noesmoen, A. 1957b. Mission charbon. Bassin de Nouméa. Rapport d'ensemble. BUMIFOM (Bureau Minier de la France d'Outre Mer) Report.

Noesmoen, A. 1959a. Le charbon en Nouvelle-Calédonie. BUMIFOM (Bureau Minier de la France d'Outre Mer) Report.

Noesmoen, A. 1959b. Mission charbon. Rapport final. BUMIFOM (Bureau Minier de la France d'Outre Mer) Report.

Noesmoen, A. 1970. Notice explicative sur la feuille Nouméa. Carte géologique à l'échelle du 1/50000. Carte BRGM - Nouvelle-Calédonie, 1-20.

Nouzé, H., Cosquer, E., Collot, J., Foucher, J.-P., Klingelhoefer, F., Lafoy, Y. \& Géli, L. 2009.

Geophysical characterization of bottom simulating reflectors in the Fairway Basin (off New Caledonia, Southwest Pacific), based on high resolution seismic profiles and heat flow data. Marine Geology, 266, 80-90, doi: 10.1016/j.margeo.2009.07.014. 
Obellianne, J.B. 1958. Le gisement de phosphate de Tiga (lles Loyauté). Rapport Interne de la Compagnie française des phosphates d'Océanie., 1-75.

Oudin, E., Bouladon, J. \& Paris, J.P. 1985. Vers hydrothermaux fossiles dans une minéralisation sulfurée des ophiolites de Nouvelle-Calédonie. Comptes Rendus de l'Académie des Sciences, 301, 157-162.

Paquette, J.L. \& Cluzel, D. 2007. U-Pb zircon dating of post-obduction volcanic-arc granitoids and a granulite-facies xenolith from New Caledonia. Inference on Southwest Pacific geodynamic models. International Journal of Earth Sciences (Geologische Rundschau), 96, 613-622, doi: doi : 10.1007/s00531-006-0127-1.

Paris, J.P. 1981. Géologie de la Nouvelle-Calédonie. Mémoire du Bureau de Recherche Géologique et Minière, 113, 1-279.

Paris, J.P. 1982. Expertise du site d'implantation d'une carrière de pierre marbrière au lieu-dit Kingak (région de Koumac). bureau de Recherches Géologiques et Minières report BRGM 82 NOU 009.

Pascal, A., Rio, M. \& Vanney, J. 1992. Les Surfaces durcies des pentes bathyales de NouvelleCaledonie (Pacifique du SW); morphologie et diagenese. Bulletin de la Societe Geologique de France, 163, 271-280.

Patriat, M., Collot, J., Danyushevsky, L., Fabre, M., Meffre, S., Falloon, T., Rouillard, P., Pelletier, B., Roach, M. \& Fournier, M. 2015. Propagation of back-arc extension into the arc lithosphere in the southern New Hebrides volcanic arc. Geochemistry, Geophysics, Geosystems, 16, 3142-3159, doi: 10.1002/2015GC005717.

Pelletier, B., Chevillon, C., Menou, J.L., Butscher, J., Folcher, E., Geoffray, C., Bore, J.M., Panché, J.Y. \& Perrier, J. 2006. Plongées, forage et cartographie Baie du Prony et Banc Gail, lagon Sud de Nouvelle-Calédonie, NO, ALIS, 13-17 juin 2004 et cartographie baie 25 du Prony NO, ALIS, 25-26 septembre 2005,. Internal Report IRD.

Picard, M. 1995. Ouverture de bassins marginaux dans le Pacifique sud-ouest. Paléovolcanisme et reconstitution des environnements géodynamiques. Extrémité nord de la Nouvelle-Calédonie. Unpubl. MSc thesis, Grenoble University, France, 1-124.

Pichocki, C. \& Hoffert, M. 1987. Etude de quelques encroûtements ferromanganésifères et de quelques sédiments provenant du domaine océanique de la Nouvelle-Calédonie. Rapport Interne, Université L. Pasteur, Strasbourg, 1-33.

Piroutet, M. 1917. Etude stratigraphique sur la Nouvelle-Calédonie. Ph D. thesis memoir, Université de Paris.

Podwojewski, P. 1988. Les vertisols de Nouvelle-Calédonie. Cahier ORSTOM, série Pédologie, XXIV, 279-301.

Podwojewski, P. 1992. Les vertisols à gypse de Nouvelle-Calédonie dans leur environnement pédologique. Ph D. thesis memoir, Université Louis Pasteur de Strasbourg. 
Podwojewski, P. 1993. Mise en évidence d'une source détritique ultrabasique dès l'Eocène moyen dans les flyschs du bassin de Nouméa, Nouvelle-Calédonie. Comptes Rendus de l'Académie des Sciences, 316, série II, 1423-1430.

Podwojewski, P. 1994. The origin of gypsum in vertisols in New Caledonia determinated by isotopics characteristics of sulphur. Geoderme, 63, 179-195.

Podwojewski, P. 1995. The occurence and interpretation of carbonate and sulfate minerals in a sequence of vertisols in New Caledonia. Geoderma, 65, 223-248.

Pomeyrol, R. 1951. Rapport sur les possibilités d'existence de gisements de pétrole en NouvelleCalédonie. Revue de l'Institut Français du Pétrole, 6, 271-282.

Pomeyrol, R. 1952. Le problème du charbon en Nouvelle-Calédonie. BUMIFOM (Bureau Minier de la France d'Outre Mer) Report.

Pomeyrol, R. 1955. Société de recherche et d'exploitation de pétrole en Nouvelle-Calédonie (SREPNC). Synthèse des résultats obtenus à la date du 30 avril 1955. Internal report.

Quéméneur, M., Bes, M., Postec, A., Mei, N., Hamelin, J., Monnin, C., Chavagnac, V., Payri, C., Pelletier, B., Guentas-Dombrowsky, L., Gérard, M., Pisapia, C., Gérard, E., Ménez, B., Ollivier, B. \& Erauso, G. 2014. Spatial distribution of microbial communities in the shallow submarine alkaline hydrothermal field of the Prony Bay, New Caledonia. Environmental Microbiology Reports, 6, 665-674.

Quesnel, B., Gautier, P., Boulvais, P., Cathelineau, M., Maurizot, P., Cluzel, D., Ulrich, M., Guillot, S., Lesimple, S. \& Couteau, C. 2013. Syn-tectonic, meteoric water-derived carbonation of the New Caledonia peridotite nappe. Geology, 2-5, doi: 10.1130/G34531.1.

Ravenne, C., de Broin, C.E., Dupont, J.P., Lapouille, A. \& Launay, J. 1977. New Caledonia BasinFairway Ridge: Structural and sedimentary study. International Symposium on Geodynamic in SouthWest Pacific, Nouméa (New Caledonia), 1976, Technip Ed., Paris, 145-154.

Ravenne, C., Dunand, J.P., de Broin, C.E., Aubertin, F. 1982. Les bassins sédimentaires du SW Pacifique. in: Contribution à l'étude géodynamique du SW Pacifique.Paris. Trvaux et documents de I'ORSTOM, 147, 461-477.

Rodgers, K.A. 1973. Felsic plutonic rocks from the southern portion of the New Caledonian ultramafic belt. Geological Magazine of Great Britain, 110, 431-446.

Rodgers, K.A. 1976. Ultramafic and related rocks from Southern New Caledonia. Bulletin du Bureau de Recherches Géologiques et Miniéres, France, 1, 33-55.

Rose, G. 1837. Mineralogisch-geognostische Reise nach dem Ural, dem Altai und dem Kapischen Meere. Sanderschen Buchandlung, Berlin, 641. 
Rossfelder, A. 1986. Rapport sur l'éxécution de la campagne de recherches CORAL-1 à bord du N.O. Vauban. POR iles Chesterfield et région Huon-d'Entrecasteaux. Rapport G.I.E. Austral Minier.

Rougerie, F., Jehl, C. \& Trichet, J. 1997. Phosphorous pathways in atolls: interstitial nutrient pool, cyanobacterial accumulation an Carbonate-Fluoro-Apatite (CFA) precipitation. Marine Geology, 139, 201-217.

Rougerie, F. \& Wauthy, B. 1989. Une nouvelle hypothèse sur la genèse des phosphates d'atolls: le rôle du processus endo-upwelling. Comptes Rendus de l'Académie des Sciences, 308, 1043-1047.

Rouillard, P., Collot, J., Bache, F., Sutherland, R., Kroeger, K. \& Funnell, R. 2014. Petroleum implications of stacked deltas in the Fairway Basin, offshore New Caledonia, Northern Tasman Frontier APPEA 2014 Conference \& Exhibition Extended Abstract.

Rouillard, P., Collot, J., Sutherland, R., Bache, F., Patriat, M. \& Maurizot, P. 2015. Seismic stratigraphy and palaeogeographic evolution of Fairway Basin, Northern Zealandia, Southwest Pacific: from Cretaceous Gondwana breakup to Cenozoic Tonga-Kermadec subduction. Basin Research, 124, doi: $10.1111 /$ bre.12144.

Routhier, P. 1953. Etude géologique du versant occidental de la Nouvelle-Calédonie entre le col de Boghen et la pointe d'Arama. Mémoire de la Société Géologique de France, XXXII 1-3 1-271.

Schrenk, M.O., Brazelton, W.J. \& Lang, S.Q. 2013. Serpentinization, Carbon, and Deep Life. In: Hazen, R.M., Jones, A.P., Baross, J.A. (Eds.), Carbon in Earth. Reviews in Mineralogy \& Geochemistry, 575-606.

Sevin, B., Cluzel, D., Maurizot, P., Ricordel-Prognon, C., Chaproniere, G., Folcher, N. \& Quesnel, F. 2014. A drastic lower Miocene regolith evolution triggered by post obduction slab break-off and uplift in New Caledonia. Tectonics, 33, doi: doi:10.1002/2014TC003588.

Sillitoe, R.H. 2010. Porphyry Copper Systems. Economic Geology, 105, 3-41.

Spandler, C., Hermann, J., Arculus, R. \& Mavrogenes, J. 2004a. Geochemical heterogeneity and element mobility in deeply subducted oceanic crust; insights from high-pressure mafic rocks from New Caledonia. Chemical Geology, 206, 21-42.

Spandler, C., Hermann, J. \& Rubatto, D. 2004b. Exsolution of thortveitite, yttrialite, and xenotime during low-temperature recrystallization of zircon from New Caledonia, and their significance for trace element incorporation in zircon. American Mineralogist, 89, 1795-1806.

Spandler, C., Rubatto, D. \& Hermann, J. 2005. Late Cretaceous- Tertiary tectonics of the southwest Pacific: Insights from U-Pb sensitive, high-resolution ion microprobe (SHRIMP) dating of eclogite facies rocks from New Caledonia. Tectonics, 24.

Sutherland, R., Viskovic, G.P.D., Bache, F., Stagpoole, V.M., Cpllot, J., Rouillard, P., Hashimoto, T., Hackney, R., Higgins, K., Rollet, N., Patriat, M. \& Roest, W.R. 2012. Compilation of seismic reflection data from the Tasman Frontier region, southwest Pacific. GNS Science Report 2012/01. New Zealand, GNS Science. 
Tercinier, G. 1963. Les sols de la Nouvelle-Calédonie. ORSTOM, Institut Français d'Océanie, 1-51.

Tercinier, G. 1971. Sols des karsts de l'atoll surélevé de Lifou (îles Loyauté, Territoire de la NouvelleCalédonie) et problème de la bauxitisation. Comptes Rendus de l'Académie des Sciences, D. Fr., 2067-2070,.

Tercinier, G. 1972. La crandallite, phosphate naturel répandu dans les sols et souvent abondant dans les produits de remplissage des karsts. Comptes Rendus Hebdomadaires des Séances de l'Académie des Sciences. Série D: Sciences Naturelles, 1445-1448.

Tessarolo, C. 1997. The Pindaï Peninsula limestone resource. Result of the 1996 coring campaign resource evaluation. Goro Nickel internal report, 1-76.

Tikkanen, G.D. 1986. World resources and supply of lead and zinc. in Bush, W.R., ed., Economics of Internationally Traded Minerals: Society of Mining Engineers, Inc., 242-250.

Tissot, B. \& Noesmoen, A. 1958. Les bassins de Nouméa et de Bourail (Nouvelle-Calédonie). Revue de l'Institut Français du Pétrole, 739-759.

Turner, F.J. 1935. Geological investigation of the Nephrite, Serpentines and Related Greenstones used by the Maoris of Otago and South Canterbury. Transactions of the Royal Society of New Zealand, 65, 187-231.

Uruski, C.I. 2008. Deepwater Taranaki, New Zealand: structural development and petroleum potential. Exploration Geophysics, 39, 94-107.

Vanney, J.R., Rio, M., Roux, M. \& H., G. 1992. Morphologie sous-marine particulière liée à des circulations hydrothermales sur la ride des Loyauté (Nouvelle-Calédonie, SW Pacifique). Bulletin de la Societe Geologique de France, 8, 163, 255-262.

Vially, R. \& Bernard, F. 1999. Potentiel pétrolier de l'offshore de Nouvelle-Calédonie. Rapport régional d'évaluation pétrolière. Insitut Français du Pétrole.

Vially, R. \& Lafoy, Y. 2005. Principales conclusions sur le potentiel pétrolier des bassins de NouvelleCalédonie et de fairway à la lumière des résultats de la campagne ZoNéCo II. Rapport ZoNéCo 11. Institut Français du Pétrole, Direction des Mines et de l'Energie de la NouvelleCalédonie.

Vially, R. \& Lafoy, Y. 2008. Synthèse du potentiel pétrolier de la Nouvelle-Calédonie. Zoneco program Report. Institut Français du Pétrole. Nouméa. New Caledonia.

Vially, R. \& Mascle, A. 1994. Rapport régional non exclusif d'évaluation pétrolière. La NouvelleCalédonie. Rapport IFP/DHYCA.

Zharikov, V.A., Pertsev, N.N., Rusinov, V.L., Callegari, E. \& Fettes, D.J. 2007. Metasomatism and metasomatic rocks. Recommendations by the IUGS Subcommission on the Systematics of Metamorphic Rocks. 


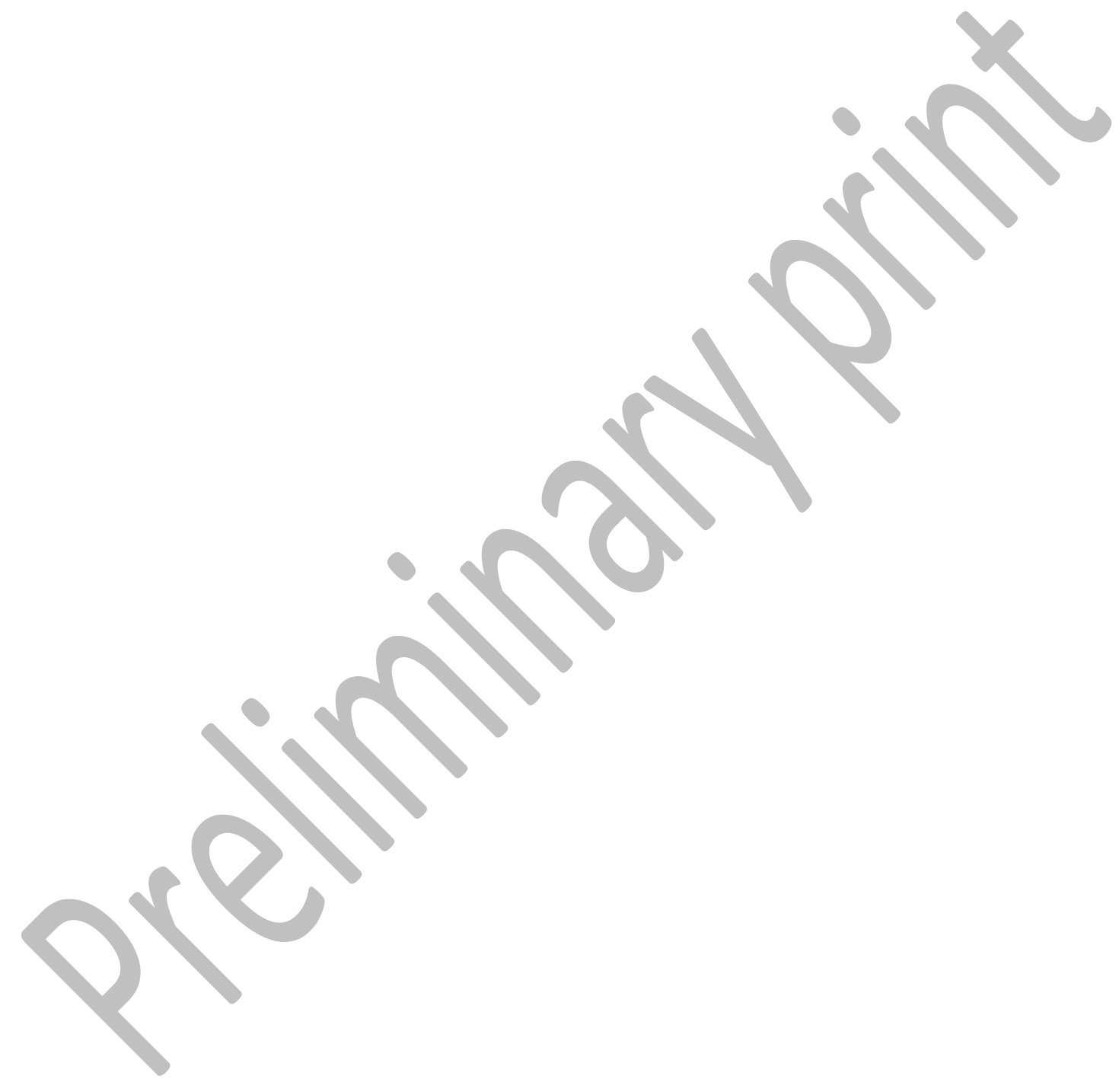

